\title{
Physical activity promotion in the health care setting in Switzerland
}

Martin, Brian W ; Padlina, Oliver ; Martin-Diener, Eva ; Bize, Raphael ; Cornuz, Jacques ; Kahlmeier, Sonja

Posted at the Zurich Open Repository and Archive, University of Zurich

ZORA URL: https://doi.org/10.5167/uzh-98313

Journal Article

Originally published at:

Martin, Brian W; Padlina, Oliver; Martin-Diener, Eva; Bize, Raphael; Cornuz, Jacques; Kahlmeier, Sonja (2014). Physical activity promotion in the health care setting in Switzerland. Schweizerische Zeitschrift für Sportmedizin und Sporttraumatologie, 62(2):19-22. 
Revue suisse de Médecine et traumatologie du sport

Rivista svizzera di Medicina e traumatologia dello sport

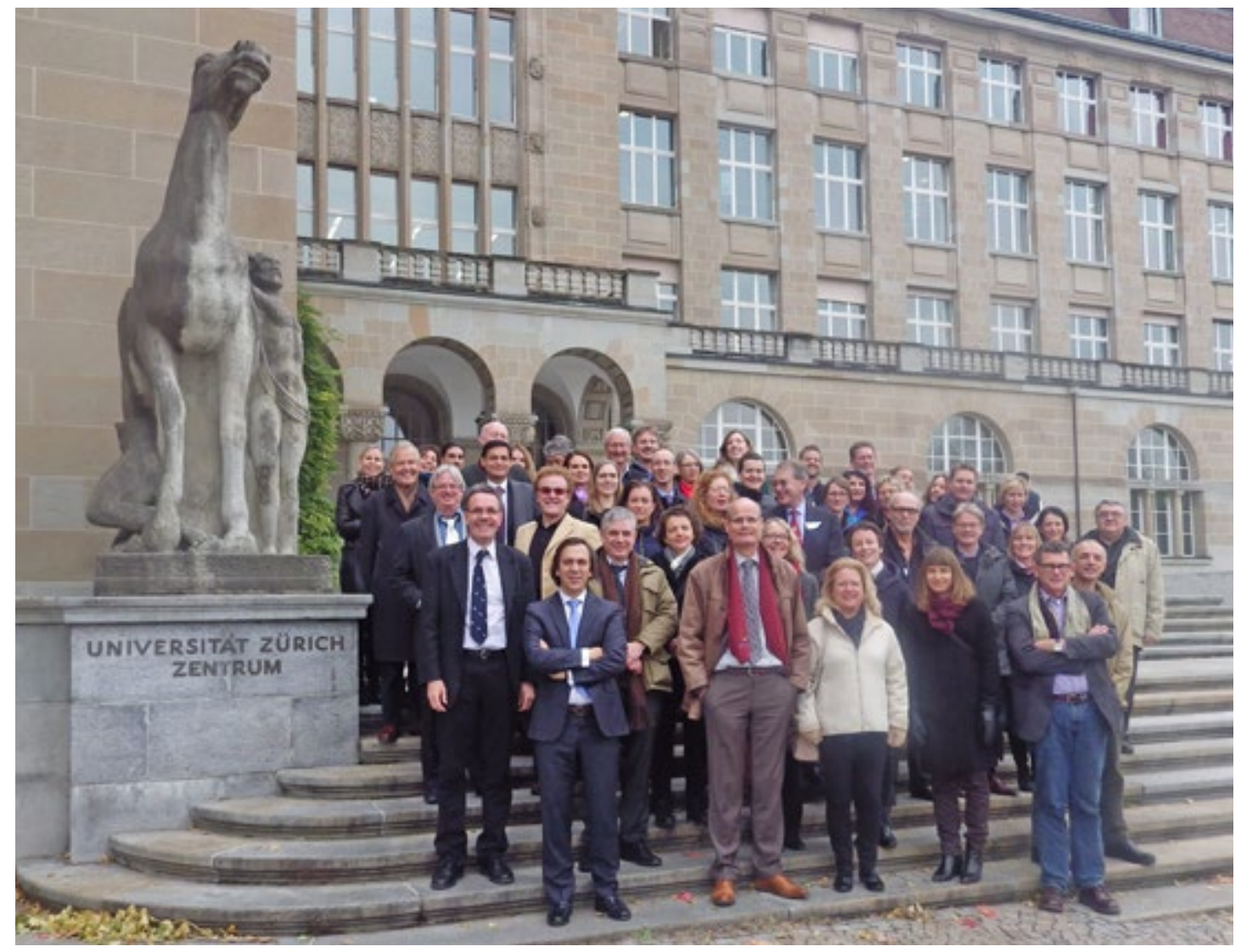

Redaktion:

Gérald Gremion, Lausanne

Victor Valderrabano, Basel • Susi Kriemler, Zürich • Boris Gojanovic, Magglingen • André Leumann, Basel Guest Editor Brian Martin

rubmedia 

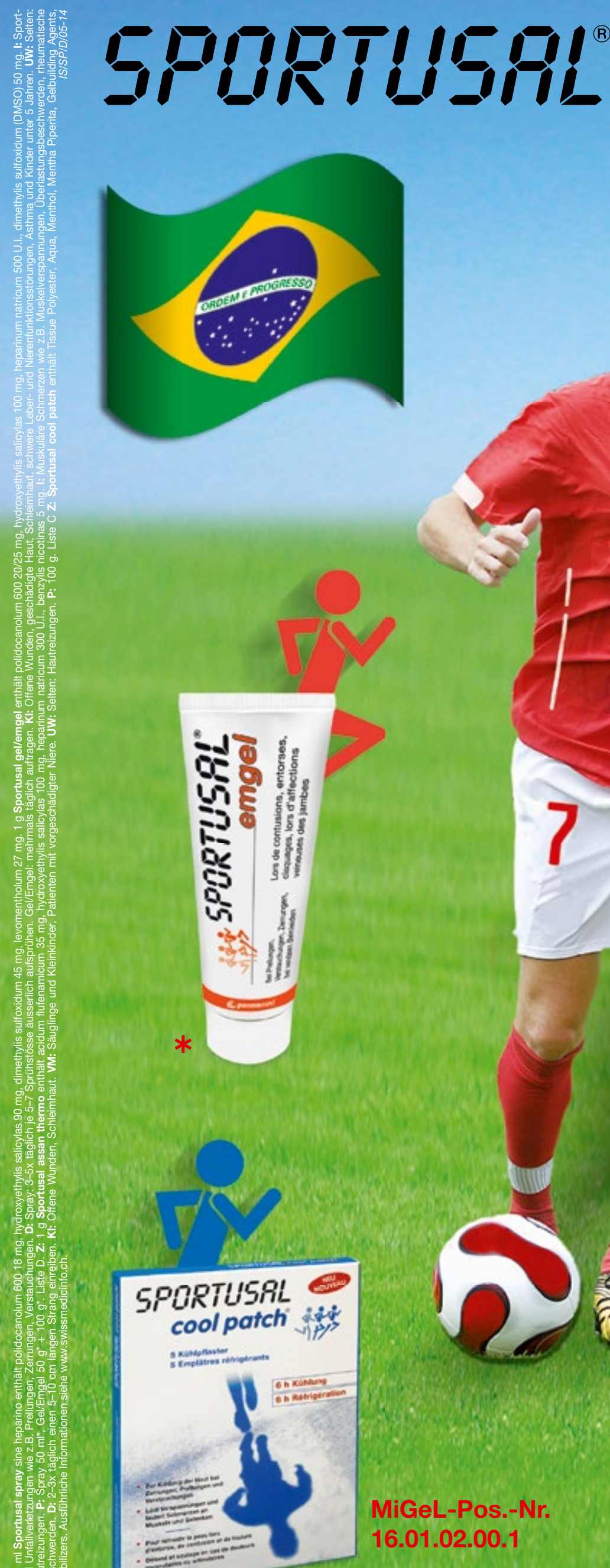

MiGel-Pos.-Nr. 16.01.02.00.1 


\section{Table of contents}

\section{Editorial}

Brian Martin

Editorial

Review

Eva Martin-Diener

10 years of HEPA Europe: what made it possible and what is the

Sonja Kahlmeier

Brian Martin

A systematic overview of institutions and bodies active in physical activity promotion in Europe

Anders Raustorp

Physical activity promotion in the health care setting in Switzerland

Malcolm Ward

The Evolution of Physical Activity on Prescription (FaR) in Sweden

Experiences in physical activity promotion in health care settings

Eszter Füzéki for primary prevention in the UK

Janet Djomba

Exercise Referral in Germany

Rimma Potemkina

Physical activity promotion in primary health care in Slovenia

Exercise in medicine in Rusia

John Duperly

"Exercise is Medicine" in Latin America: training health care professionals in physical activity prescription

Felipe Lobelo

Physical Activity Promotion in Health Care Settings: the

"Exercise is Medicine" Global Health Initiative Perspective.

\section{Education SGSM/SSMS}

Kurse - Zertifikationskurs - Examen - Sportmed Tagung - Kongress 46 Cours - Cours de certification - Examen - Journée Sportmed - Congrès 46

Titelbild: Participants of the WHO Expert Meeting on Physical Activity Promotion in Health Care Settings, University of Zurich, 12-13 November 2013. Photograph made available by Dr. João Breda, WHO Regional Office for Europe, Copenhagen. Foto: unbekannte Studentin mit der Kamera von João Breda.

Impressum: $\quad$ Volume 62 / 2014 ISSN 1422-06 44, 4 Ausgaben / Jahr

Sekretariat und Administration: Schweizerische Zeitschrift für Sportmedizin und Sporttraumatologie, Postfach 604, CH-3000 Bern 25, Telefon 03133302 54, Telefax 03133298 79, info@sgsm.ch, www.sgsm.ch und www.ssms.ch

Anzeigen, Verlag und Druck: rubmedia Postfach 6364, CH-3001 Bern,

Telefon 03138014 80, Fax 03138014 89, www.rubmedia.ch, zeitschriftenverlag@rubmedia.ch

Abonnemente:

IPO Service AG, Abodienst Rub Media AG, Industriestrasse 37, CH-3178 Bösingen

Telefon 03174097 86, Telefax 03174097 76, abo-sportmedizin@rubmedia.ch 


\section{Editorial}

\section{Health-enhancing physical activity in Europe and in Switzerland: the health care setting and beyond}

Five years ago the Swiss Journal for Sports Medicine and Sports Traumatology already had a thematic issue on physical activity and health which was mainly dealing with the situation and work done in Switzerland (Martin et Mäder, 2009). The current one has more of an international perspective. The occasion for most of the contributions was the Expert Meeting on "Physical Activity Promotion in Health Care Settings" organised at the University of Zurich with the Regional Office for Europe of the World Health Organisation WHO in November 2013. Its first purpose was to provide an overview of the current state and ongoing developments in the field and most of the articles presented here have originated from presentations given during the expert meeting. The Nordic Countries and the United Kingdom have been the front runners in the development of physical activity promotion in health care. The articles by Raustorp and by Ward are providing an overview about the current situation in Sweden and in Wales respectively. But developments are underway in other countries as well: Germany, Slovenia, Russia and also Switzerland are covered in the contributions by Fücéki, Djomba, Potemkina and Martin. As Zurich was the first ever WHO expert meeting on this topic on a global scale, there were also participants and contributors from overseas. Lobelo gives an overview of the activities of the global "Exercise is Medicine" initiative pioneered by the American College of Sports Medicine, and Duperly covers the specific experiences in Latin America. The second purpose of the meeting was to identify lessons learned and remaining challenges, so the results of the meeting could "provide the basis for the definition of priorities for future action in the European region". In the final discussion, the more than 50 international experts agreed on the "Zurich Declaration" outlining the further development in this field (table 1).

"Physical Activity Promotion in Health Care Settings" will also be the main topic of the 10th annual meeting and the 5th Conference of HEPA Europe, the European network for health enhancing physical activity taking place at the University of Zurich on 27 to 29 August 2014. The event will have the patronage of several international and national organisations including the Swiss Society for Sports Medicine. The article by Martin-Diener highlights the contributions from Switzerland and other countries which have made it possible for HEPA Europe to play an important role in the development of physical activity promotion on our continent over the last decade. Kahlmeier in her contribution gives an overview of the other organisations active in this field.

Our article on the situation in Switzerland not only presents our national approach PAPRICA (Physical Activity Promotion in PRImary Care), but also gives a short overview of the current overall situation concerning physical activity in our country. This provides the opportunity for reflection on pro- gress in physical activity in Switzerland over the last few years - also in view of recent comparative research between European countries (Bull et al, in press). Switzerland continues to have good conditions and a strong tradition of active transport to school as well as of walking, both for commuting purposes and as a leisure time activity. Sport for all has strong structures including the role of sport clubs and associations, the national Youth and Sports programme and physical education in schools. The latest data on physical activity still suffers from the same methodological limitations already described five years ago (Martin et al, 2009), but the developments at least in adults' behavioural patterns are encouraging. This is probably an expression of the many promotional activities at the level of the communities and the cantons as well as within private organisations, and of favourable developments particularly in urban planning and transport. The over-

Table 1: The "Zurich Declaration on Physical Activity Promotion in Health Care Settings" developed at the first ever WHO Expert Meeting on this topic in November 2013. The complete and final wording of the declaration can be found in the final official meeting report.

1. Physical activity promotion in health care settings should be put in the context of overall physical activity promotion and its different evidence-based approaches

2. Stewardship for physical activity promotion in health care settings lies with the health sector, and at the international level with WHO

3. Physical activity promotion in health care settings deals with the complete spectrum of physical activity, from the reduction of sedentary behaviour over activities in daily life and exercise to sport for all, and includes physical activity for primary prevention, therapy and rehabilitation

4. All health professions should be integrated and develop their potential and opportunties in physical activity promotion in health care settings

5. Physical activity promotion in health care settings should be integrated and supported in national physical activity policies, strategies and programme structures

6. Drawing from national and international experiences and targeted research, the evidence base for physical activity promotion in health care settings should be improved and specific guidance developed 
all assessment of the developments concerning the national sport and health sectors is less optimistic. The Swiss Federal Government's Concept for a National Sport Policy in the year 2000 had defined "more physically active people" as its first objective and also the Federal Law on Sports Promotion revised in 2011 provides a good basis for activities in this field. However, when the draft ordinances regulating the implementation of the law were presented, they contained only very limited elements in this direction. Therefore, during the consultation process the Swiss Society for Sports Medicine, Public Health Switzerland, the Swiss Medical Association and several other related organisations made a number of comments and recommendations with respect to population reach activities in children and in adults, external evaluation and accountability. None of these recommendations were integrated in the final ordinances (Martin et al, 2014).

After WHO's Global Strategy on Diet, Physical Activity and Health was published in 2004, the Swiss Federal Federal Government commissioned the development of a national programme in this field. It is in place since 2008, but still today it does not have measurable objectives. Following a critical evaluation report (von Stokar et al, 2011), an analysis was commissioned and resulted in recommendations for developments within the federal administration (Lamprecht et al, 2013). Our own analysis of physical activity promotion in Switzerland (Martin et al, 2014) for the national "NGO Alli-

\section{References}

Bull F., Milton K., Kahlmeier S., Arlotti A., Backović Juričan A., Belander O., Martin B. W., Martin-Diener E., Marques A., Mota J., Vasankari T., Vlasveld A. (in press): Turning the Tide: national policy approaches to increasing physical activity in seven European countries. Brit. J. Sports Med. Martin B. W., Mäder U. (2009): Physical activity and health in Switzerland - where are we in 2009? Editorial. Schweiz Z Sportmed Sporttraumatol 57 (2): 36 .

Martin B. W., Mäder U., Stamm H. P., Braun-Fahrländer C. (2009): Physical activity and health - what are the recommendations and where do we find the Swiss population? Schweiz Z Sportmed Sporttraumatol 57 (2): 37-43.

Martin B. W., Martin-Diener E., Kahlmeier S. (2014). Bewegungsförderung in der Schweiz. Schlussbericht, 20.03.14. Institut für Sozial- und Präventivmedizin, Zürich.

Stamm H. P., Gebert A., Wiegand D., Lamprecht M. (2013): Die Förderung gesundheitswirksamer Bewegung und der Kampf gegen die Inaktivität. Situationsanalyse und Definition der Rolle des Bundesamtes für Gesundheit. Lamprecht und Stamm Sozialforschung und Beratung AG, Zürich.

Von Stokar T., Stern S., Fliedner J., Dubois-Arber F., Bize R., Krafft M. (2011): Evaluation des Nationalen Programms Ernährung und Bewegung 2008-2012. Arbeitsgemeinschaft INFRAS, Institut universitaire de médecine sociale et préventive, Maud Krafft Consulting 2011, Zürich und Lausanne. ance Diet, Physical Activity, Body Weight" identified deficits at three levels: lack of leadership and direction at the national level, lack of stewardship and accountability in implementation, lack of critical evaluation and research. Specific recommendations for the NGO Alliance were made with respect to the development of targets for physical activity promotion, to the development of an alliance of committed institutions and to capacity building.

The process for the development of a national strategy for the prevention and control of non-communicable diseases NCDs has just begun in Switzerland. NGOs and professional organisations such as Public Health Switzerland, the Swiss Society for Sports Medicine and the Swiss Medical Association have an important role in assuring that such processes do not only result in the multiplication of administrative structures and of coordination efforts, but in targeted action, accountability for the use of public funding, and in the facilitation of critical research according to international standards. Evidence based measures delivered through professional structures play an important role in the fight against NCDs - such as physical activity promotion in health care settings.

Brian W. Martin, MD MPH

Institute of Social and Preventive Medicine University of Zurich
Corresponding author:

Brian Martin, MD MPH, Head Physical Acitity and Health Unit, Institute of Social and Preventive Medicine University of Zurich, Seilergraben 49, Room D-03 CH-8001 Zurich, Telephone: +41 446344557

E-Mail: brian.martin@uzh.ch 


\title{
10 years of HEPA Europe: what made it possible and what is the way into the future?
}

\author{
Eva Martin-Diener ${ }^{1}$, Sonja Kahlmeier ${ }^{1}$, Anne Vuillemin², Willem van Mechelen ${ }^{3}$, Tommi Vasankari ${ }^{4}$, \\ Francesca Racioppi ${ }^{5}$, Brian W. Martin ${ }^{1}$ \\ ${ }^{1}$ Institute of Social and Preventive Medicine, University of Zurich, Switzerland \\ 2 University of Lorraine, EA4360 APEMAC, Faculty of Sport, France \\ ${ }^{3}$ Department of Public \& Occupational Health and EMGO+ Institute, VU University Medical Centre, Amsterdam, \\ the Netherlands \\ ${ }^{4}$ UKK Institute for Health Promotion Research, Tampere, Finland \\ ${ }^{5}$ World Health Organization Regional Office for Europe
}

\begin{abstract}
HEPA Europe, the European network for the promotion of health-enhancing physical activity, will have its $10^{\text {th }}$ annual meeting in 2014. Membership of the network has grown to 129 institutions from 32 countries. Collaborations have been established with the World Health Organization (WHO), the European Union (EU), Agita Mundo, the global network for physical activity promotion, other regional networks, and the International Society for Physical Activity and Health. Physical activity has moved up on the public agenda; in 2013 the EU Council adopted its first ever Council Recommendation in sport, notably on promoting health-enhancing physical activity, and in 2014 WHO has begun the development of a Physical Activity Strategy for the European region. HEPA Europe has had strong involvement in these developments despite the absence of a long-term funding mechanism, changing priorities within its supporting institutions and difficulties of earlier attempts to establish a European physical activity network. This article reflects on four groups of enabling factors for this development. 1) The time was right: favourable secular developments, products of previous work and the momentum of an international pioneer phase met with windows of opportunity in key institutions. 2) A combination of commitment and conceptual clarity: clearly defined objectives, structures and approaches provided opportunities for individual commitment to blossom. 3) Institutional support: structural attachment to WHO and steady support from a sequence of key institutions was provided. 4) The deliverance of high visibility products: HEPA Europe's events, its working groups, as well as its tools met with great interest. In Europe, the HEPA network has found a role which is not filled by any other institution and which is increasingly in demand. To meet these growing and changing expectations, HEPA Europe will need to continue evolving. This will take dedicated individuals, supportive member institutions as well as sustainable funding mechanisms.
\end{abstract}

Keywords: Physical activity, public health, network, enabling factors, Europe

\section{Zusammenfassung}

HEPA Europe, das europäische Netzwerk für Bewegungsförderung, wird 2014 sein zehntes Jahrestreffen durchführen. Es zählt heute 129 Mitgliederinstitutionen aus 32 Ländern. Die Zusammenarbeit mit der Weltgesundheitsorganisation (WHO), der Europäischen Union (EU), Agita Mundo, dem globalen Netzwerk zur Bewegungsförderung, anderen regionalen Netzwerken und der internationalen Gesellschaft für Bewegung und Gesundheit (ISPAH) sind etabliert. Politisch hat das Thema Bewegung an Bedeutung gewonnen; 2013 gab die EU ihre ersten Sport-Empfehlungen heraus, nämlich zu gesundheitsförderlicher Bewegung, und 2014 nahm die WHO die Entwicklung einer Bewegungsförderungsstrategie für Europa in Angriff. HEPA Europe war an diesen Entwicklungen namhaft beteiligt; dies ohne längerfristige Finanzierungsmechanismen, trotz Veränderungen bei den Prioritäten seiner unterstützenden Institutionen und früherer Schwierigkeiten bei der Etablierung eines Netzwerks. Dieser Artikel reflektiert vier Gruppen von Faktoren, welche die Entwicklung von HEPA Europe begünstigten. 1) Die Zeit war reif: günstige gesamtgesellschaftliche Entwicklungen, die Früchte früherer Anstrengungen und der Schwung einer internationalen Pionierphase fielen zusammen mit günstigen Konstellationen in Schlüsselinstitutionen. 2) Kombination von Engagement und konzeptioneller Klarheit: klar definierte Ziele, Strukturen und Prozesse ermöglichten die Entfaltung individuellen Engagements. 3) Institutionelle Unterstützung: strukturelle Anbindung an die WHO und Unterstützung durch wechselnde Schlüsselinstitutionen waren wichtig. 4) Sichtbare Produkte: die Anlässe von HEPA Europe, seine Arbeitsgruppen und Instrumente trafen auf Interesse. HEPA Europe erfüllt eine Rolle in Europa, welche von keiner anderen Institution eingenommen werden kann und welche je länger je mehr gefragt ist. Um zukünftigen Erwartungen gerecht zu werden, muss sich das Netzwerk weiter entwickeln. Es wird dazu engagierte Fachleute, unterstützende Institutionen sowie nachhaltige Finanzierungsmechanismen brauchen.

Schlüsselwörter: Physical activity, public health, network, enabling factors, Europe 


\section{HEPA EUROPE - where are we today?}

In summer 2004, the launch of a European physical activity promotion network was decided during an expert meeting in Magglingen, Switzerland, with participants from European countries, the World Health Organization (WHO) and Agita Mundo, the global physical activity promotion network. After a one year preparation period, HEPA Europe, the European network for health-enhancing physical activity (HEPA) was officially founded at its first meeting on 26-27 May 2005 in Gerlev, Denmark (Martin et al., 2006). In August 2014, its $10^{\text {th }}$ annual meeting will take place in Zurich, Switzerland. In the meantime, membership of the network has grown to 129 institutions from 32 countries. Collaborations have been established with the WHO Regional Office for Europe, the European Union (EU), Agita Mundo, other regional physical activity promotion networks, and the International Society for Physical Activity and Health (ISPAH) (Martin and Kahlmeier, in press). These collaborations have for example contributed to the first ever EU Council Recommendation in the area of sport, notably on the topic of "promoting healthenhancing physical activity across sectors" (EU Council, 2013) and they are also playing a role in the development of a WHO European Physical Activity Strategy which has begun in early 2014 (WHO, 2013a). In a survey carried out between November 2010 and January 2011 in 482 members and other stakeholders of HEPA Europe from more than 30 countries, $49 \%$ reported that HEPA Europe's activities or products had had an influence on physical activity promotion in their work, in their institution or at their national level (WHO, 2012).

This development is remarkable for several reasons. Earlier attempts to establish a European physical activity network had failed. During the last decade, important member institutions of HEPA Europe have undergone changes in their priorities and were not able to continue the same level of support. And last but not least, it was not yet possible to establish a long-term funding mechanism for the network; public funding had to be secured from a series of different institutions, private funding has only played a minor role.

How was this development possible despite all these handicaps? Below we will reflect on enabling factors and will address the main challenges for HEPA Europe in the future.

\section{Enabling factors}

\section{The time was right}

There were several secular developments favouring the creation and the further development of the HEPA Europe network. The rise of obesity and non-communicable, lifestylerelated, diseases and the growing interest in population levels of physical inactivity are certainly to be listed in this context. Changes at the political level and developments in communication technology and transport had created and established new possibilities for collaboration at the European and at the global level.

HEPA Europe could build on previous work. A first European network based on a collaborative project supported by the European Commission had already made important conceptual contributions to the development of physical activity promotion since 1996, for example through cycling and walk- ing (Martin et al., 2006). A follow-up project was not funded by the European Commission in 2001, but many of the contacts established through the network remained intact, and its previous leaders from the UKK Institute in Tampere, Finland became essential supporters of HEPA Europe.

In addition to the general scientific progress on the health effects and the intervention options for physical activity, relevant cornerstones at the global level were the 1996 report of the US Surgeon General's Report on Physical Activity and Health (US Department of Health and Human Services, 1996), the work of the Physical Activity and Health Branch at the Centers for Disease Control and Prevention (CDC) in Atlanta in the following years, the development of Agita Mundo following the main event of WHO's World Day for Health in 2002 on the topic of "Physical Activity for Health" in São Paulo, Brazil (Martin and Kahlmeier, in press), and important health policy documents such as WHO's Global Strategy on Diet, Physical Activity and Health (WHO, 2004).

Thus, HEPA Europe had the opportunity to use the momentum of an international pioneer phase in physical activity and health with great commitment and enthusiasm of many people active in the field, and with a general spirit of collaboration and mutual support in research, policy and practice.

There were institutional windows of opportunity in 2004. Through the successful Transport, Health and Environment Pan-European Programme (THE PEP) (Martin et al., 2004), solid working relationships had been established between WHO, a number of European countries and also the United Nations Economic Commission for Europe (UNECE). Key individuals within the Swiss Federal Offices of Sport and Public Health were not only supportive of the expert meeting held in Switzerland in 2004, but also of the actual development of HEPA Europe. And finally, WHO's Regional Office for Europe was willing and ready to host the network.

\section{Combination of commitment and conceptual clarity}

Expertise and individual commitment are essential to make progress in any field of public health. However, only mutual agreement on objectives, structures and approaches allows combining the advantages of top-down and bottom-up approaches and making progress on a broader scale. Early on in its development, HEPA Europe defined its vision, aims and guiding principles. The development of the HEPA Europe framework and the network's impact model were other important steps.

The work of HEPA Europe is based on relevant policy statements of international bodies, such as the WHO Global Strategy for Diet, Physical Activity and Health (WHO, 2004) mentioned earlier. The Terms of Reference of HEPA Europe were drafted before and finalised at the first network meeting in 2005 (Martin et al., 2006). They have been adapted in detail since, but already in their original form they described the vision of the network, which is to achieve better health through physical activity among all people in Europe, its goals and objectives as well as its structures and functioning.

The first activities of HEPA Europe were to a large extent driven by available resources, knowledge and background of the active members, and by opportunities; they were less based on a formulated implementation strategy. In 2006, the Steering Committee started the development of an impact model for the network. In several steps six areas were identified which could be addressed with a good chance of success: social and physical environments for health-enhancing phys- 


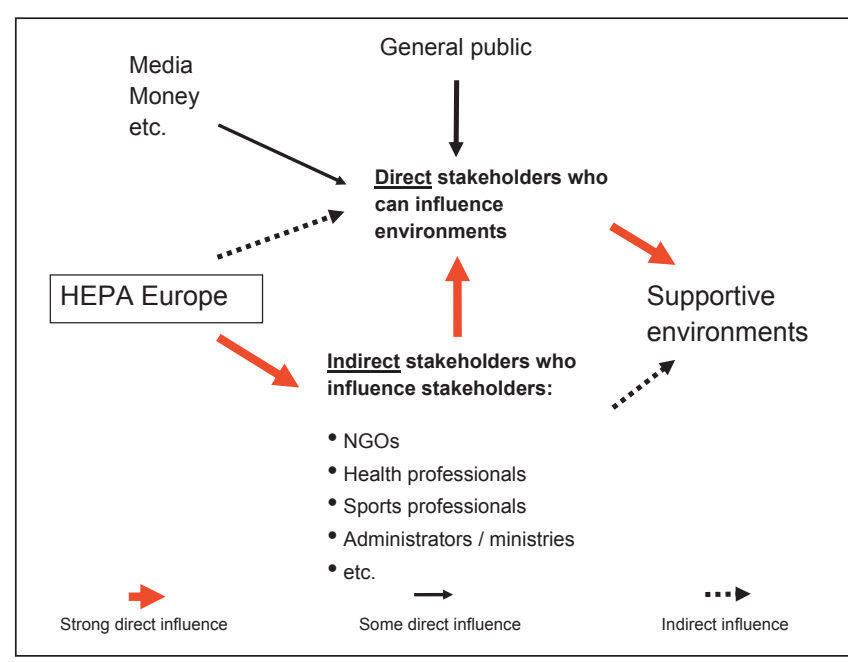

Figure 1: Simplified impact model of HEPA Europe. The model was endorsed by the members at the annual network meeting 2008 in Glasgow (WHO 2009): The most promising way for the network to address the causes of the physical inactivity problem would be to support indirect stakeholders which could then address those stakeholders who are directly in power to change environments and systems.

ical activity; cultural values regarding HEPA; recognition of benefits of HEPA by stakeholders and its role in health policy; evidence on effective interventions; HEPA-related workforce development; and coordination. At the annual network meeting 2008 in Glasgow, the HEPA Europe impact model was discussed and finalised with the network members (WHO, 2009). There was general agreement that the most promising and effective way for the network to address the causes of the physical inactivity problem would be to support indirect stakeholders such as NGOs or ministries. They could then address those stakeholders who are directly in power to change environments and systems (figure 1).

In parallel to the development of the impact model, the Steering Committee of HEPA Europe was also working on a framework to facilitate communication with decision makers and a wider audience on the principles and mechanisms of HEPA promotion at the population level. The HEPA Europe framework was based on existing models such as the public health action cycle (Institute of Medicine, 1988) and the model for policy research (Schmid et al., 2006), but it illustrated also the fact that programmes and activities can only work through the determinants of the respective domains of physical activity (figure 2). In addition, by integrating the societal context it acknowledged that in real life there are other factors, such as policies and interventions of other sectors, the social climate, or the economy which are heavily affecting all levels of HEPA promotion and often interact with specific public health interventions. Finally, the framework served to highlight the central role of the knowledge base, consisting of practical experiences and scientific evidence, for systematic progress in the field, with respect to all three types of evidence for public health (Brownson et al., 2009).

Membership to HEPA Europe is open to institutions and organisations willing to contribute to the goals and objectives of the network. The number of members increased from 36 in 2006 to 129 in 2013, representing 32 countries. The majority of members are public institutions; they are active

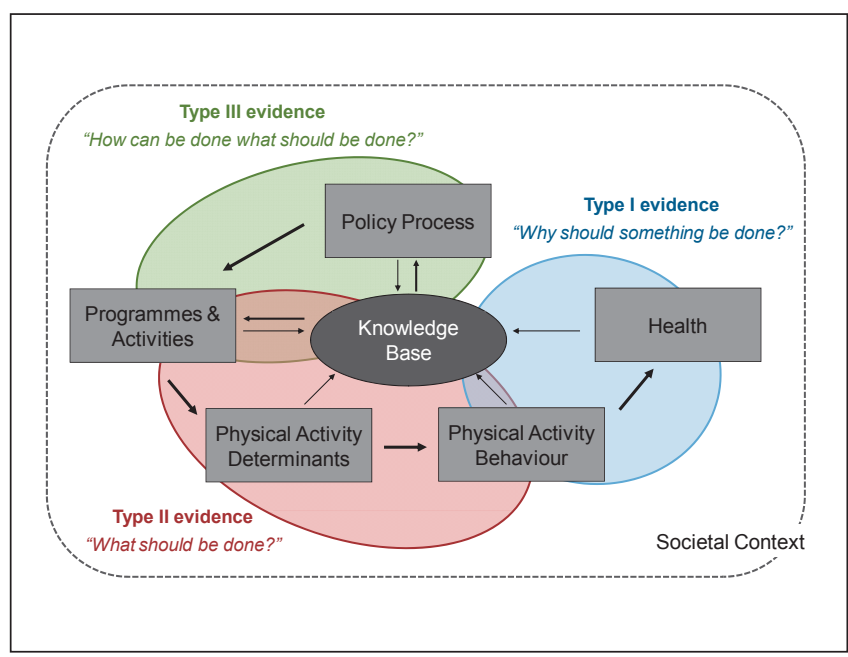

Figure 2: The HEPA Europe Framework. Encompassing the elements shown in the graph, the societal context can interact with them. The knowledge base has a central role for systematic progress in the field; it covers all three types of evidence for public health (Brownson et al, 2009).

in research, physical activity and sports promotion, teaching, advocacy, policy development or health promotion in general. The members represent a range of sectors and expertise; they are listed on the HEPA Europe website (www.euro.who.int/ hepaeurope) and in the reports of the annual network meetings (WHO, 2014). The Steering Committee of HEPA Europe has been composed by a total of 25 individuals from 13 countries since 2005 (table 1). Its members are elected for a one year term and can be re-elected. The chair has a two year term and can be re-elected once. Since 2009, the steering committee has a designated executive member.

The network's working groups (table 2) have been important for the development of methods and guidance; they range from funded research and development projects to self-financed exchange of ideas on specific topics (Vuillemin et al., 2004). The working groups are open to members of HEPA Europe and of the other physical activity networks (Martin and Kahlmeier, in press) as well as to invited experts. Large groups can consist of more than 30 members; they usually have a core group driving the work forward. In early years, the Steering Committee played an important role in organising the working groups; in the meantime a total of some 25 volunteering experts from member institutions have taken over a lead.

\section{Institutional support}

Apart from issues of financial sustainability, one of the lessons from the first European physical activity network was that the secretariat of HEPA Europe should be better affiliated to an international organization with convening powers. The WHO Regional Office for Europe has included the network as part of its technical programme of work, first at its European Centre for Environment and Health in Rome and since 2012 at its Regional Office for Europe headquarters in Copenhagen. This has provided an organisational framework for HEPA Europe, but also multiple synergies with WHO's other activities and direct connection with the work of health ministries in 
Table 1: Chairs and members of the HEPA Europe Steering Committee. Brian Martin was chairman from 2005 to 2009 , Willem van Mechelen from 2009 to 2013 and Tommi Vasankari since 2013. Until 2009, Sonja Kahlmeier was technical officer in charge of HEPA Europe at WHO's Rome office, since 2009 Executive Member of the Steering Committee.

\begin{tabular}{|c|c|c|c|c|c|c|c|c|c|c|c|}
\hline \multicolumn{2}{|c|}{ Members of the Steering Committee } & 2005 & 2006 & 2007 & 2008 & 2009 & 2010 & 2011 & 2012 & 2013 & 2014 \\
\hline Finn Berggren & $\begin{array}{l}\text { Gerlev Sports Academy, } \\
\text { Denmark }\end{array}$ & & & & & & & & & & \\
\hline Eddy Engelsman & $\begin{array}{l}\text { Ministry of Health, Welfare and } \\
\text { Sports }^{1} \text {, the Netherlands }\end{array}$ & & & & & & & & & & \\
\hline Brian Martin & $\begin{array}{l}\text { Federal Office of Sports, } \\
\text { Switzerland }^{2}\end{array}$ & & & Chairm & & & & & & & \\
\hline Mari Miettinen & $\begin{array}{l}\text { Ministry of Social Affairs and } \\
\text { Health, Finland }\end{array}$ & & & & & & & & & & \\
\hline Pekka Oja & $\begin{array}{l}\text { UKK Institute for Health } \\
\text { Promotion Research, Finland }\end{array}$ & & & & & & & & & & \\
\hline Jean-Michel Oppert & $\begin{array}{l}\text { University Pierre et Marie Curie } \\
\text { Paris 6, France }\end{array}$ & & & & & & & & & & \\
\hline Francesca Racioppi & $\begin{array}{l}\text { WHO Regional Office Europe } \\
\text { Rome then Copenhagen }\end{array}$ & & & & & & & & & & \\
\hline Harry Rutter & $\begin{array}{l}\text { South East Public Health Group }{ }^{3} \text {, } \\
\text { United Kingdom }\end{array}$ & & & & & & & & & & \\
\hline Michael Sjöström & $\begin{array}{l}\text { Karolinska Institute, } \\
\text { Sweden }\end{array}$ & & & & & & & & & & \\
\hline Radim Šlachta & $\begin{array}{l}\text { Palacký University Olomouc, } \\
\text { Czech Republic }\end{array}$ & & & & & & & & & & \\
\hline Mireille van Poppel & $\begin{array}{l}\text { VU Medical Centre, } \\
\text { the Netherlands }\end{array}$ & & & & & & & & & & \\
\hline $\begin{array}{l}\text { Jožica Maučec } \\
\text { Zakotnik }\end{array}$ & $\begin{array}{l}\text { CINDI }{ }^{4} \text { Programme, } \\
\text { Slovenia }\end{array}$ & & & & & & & & & & \\
\hline Winfried Banzer & $\begin{array}{l}\text { Goethe University Frankfurt, } \\
\text { Germany }\end{array}$ & & & & & & & & & & \\
\hline Sonja Kahlmeier & $\begin{array}{l}\text { University of Zurich, } \\
\text { Switzerland }\end{array}$ & & & & & & & Exec & e Men & & \\
\hline Tommi Vasankari & $\begin{array}{l}\text { UKK Institute for Health } \\
\text { Promotion Research, Finland }\end{array}$ & & & & & & & & & & hair \\
\hline Willem van Mechelen & $\begin{array}{l}\text { VU Medical Centre, } \\
\text { the Netherlands }\end{array}$ & & & & & & & Chairn & & & \\
\hline $\begin{array}{l}\text { Andrea Bakovic- } \\
\text { Jurican }\end{array}$ & $\begin{array}{l}\text { CINDI }{ }^{4} \text { Programme, } \\
\text { Slovenia }\end{array}$ & & & & & & & & & & \\
\hline Charlie Foster & $\begin{array}{l}\text { University of Oxford, } \\
\text { United Kingdom }\end{array}$ & & & & & & & & & & \\
\hline Maarten Koornneef & $\begin{array}{l}\text { Ministry of Health, Welfare and } \\
\text { Sports, the Netherlands }\end{array}$ & & & & & & & & & & \\
\hline Alberto Arlotti & $\begin{array}{l}\text { Public Health Office, Emilia- } \\
\text { Romagna Region, Italy }\end{array}$ & & & & & & & & & & \\
\hline Narcis Gusi & $\begin{array}{l}\text { University of Extremadura, } \\
\text { Spain }\end{array}$ & & & & & & & & & & \\
\hline Niamh Murphy & $\begin{array}{l}\text { Waterford Institute of Technology, } \\
\text { Ireland }\end{array}$ & & & & & & & & & & \\
\hline Nanette Mutrie & $\begin{array}{l}\text { University of Edinburgh, } \\
\text { United Kingdom }\end{array}$ & & & & & & & & & & \\
\hline Anne Vuillemin & $\begin{array}{l}\text { University of Lorraine, } \\
\text { France }\end{array}$ & & & & & & & & & & \\
\hline Marie Murphy & $\begin{array}{l}\text { University of Ulster, } \\
\text { United Kingdom }\end{array}$ & & & & & & & & & & \\
\hline
\end{tabular}

${ }^{1}$ later: Netherlands Institute of Sport and Physical Activity (NISB); ${ }^{2}$ later: University of Zurich, Switzerland; ${ }^{3}$ later: Obesity Observatory, UK;

${ }^{4}$ Countrywide Integrated Noncommunicable Disease Intervention 
Table 2: HEPA Europe working groups and their leaders. Details of the working groups' activities can be found in the reports of the annual network meetings (WHO 2014).

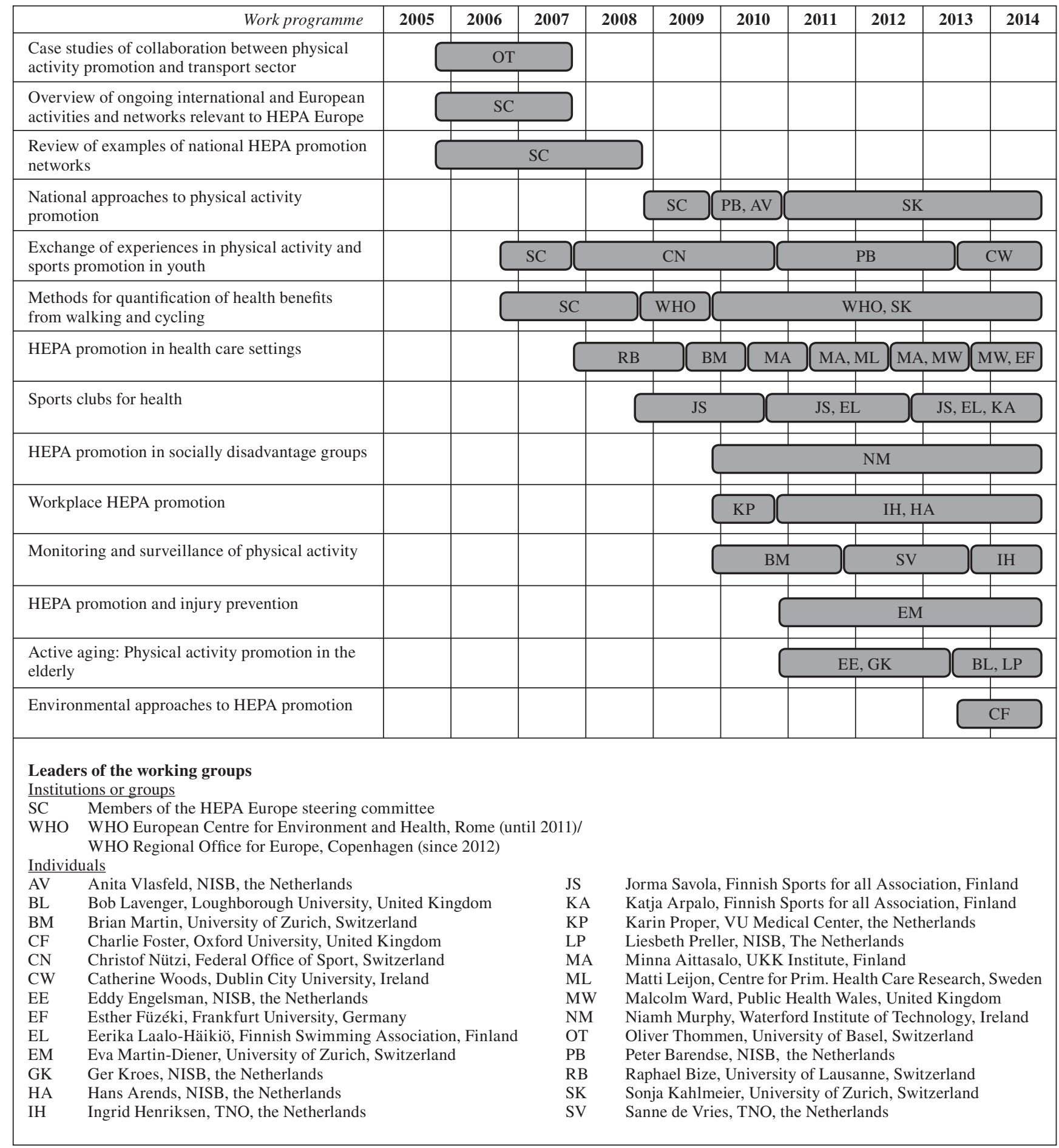

European member countries. Support was provided also by the other institutions represented in the HEPA Europe Steering Committee (table 1) and working groups (table 2). Very important were also the organisers of the annual meetings, symposia or conferences (table 3) and the hosts of the working group meetings and other events of the network. Organisations at the global level or from other world regions such as Agita Mundo, ISPAH (GAPA, 2010) or the American College for Sports Medicine with its Exercise is Medicine initiative have also been important partners.
Direct funding for HEPA Europe was provided in the first years by the Swiss Federal Offices of Sport and Public Health, in later years support was received from the ministries of Health of Italy, the Netherlands and Norway. Cooperation between WHO and the European Commission covered several projects in the range of activities and events of HEPA Europe, specific working groups were supported from different country sources. 


\section{High visibility products}

HEPA Europe has given its members a platform to exchange their ideas, to contribute to the development of tools and guidance (Vuillemin et al., 2014) and to take part in their implementation.

The number of participants at the annual network meetings has increased steadily. The conferences or symposia combined with the meetings since 2008 have further added to their attractiveness (table 3). Members of the network have played an important role in key publications in the field such as WHO's "Physical activity and health in Europe: evidence for action" (WHO, 2006a) as well as in expert groups of WHO (WHO, 2006b; Branca, Nikogosian and Lobstein, 2007) and the European Union (EU, 2008).

Several of HEPA Europe's working groups have organised separate events, most recently the WHO Expert Meeting on Physical Activity Promotion in Health Care Settings at the University of Zurich in 2013 (Martin, 2014). They have developed specific products such as the Health Economic Assessment Tool Walking and Cycling (www.euro.who.int/ HEAT, Rutter et al., 2013), the HEPA Policy Audit Tool (www.euro.who.int/hepapat, Bull et al., 2014) and guidance and recommendations on a whole range of topics, including national physical activity recommendations (Oja et al., 2010), the role of sport clubs for health (Kokko et al., 2009) or physical activity promotion in socially disadvantaged groups (WHO, 2013b). A complete list of products of HEPA Europe and its working groups can be found in the reports of the annual network meetings (WHO, 2014).

\section{The way ahead}

Despite a number of challenges, HEPA Europe, the European network for health-enhancing physical activity, has been able to make a contribution to physical activity and health in Europe over the last ten years. The coincidence of a number of favourable developments during its nascency, the combination of commitment and conceptual clarity, institutional support at several levels and the network's ability to produce high visibility output in a timely fashion have made this possible.

Analyses of inter-organisational networks have described a number of factors as important for the effectiveness of collaborative partnerships (Broesskamp-Stone 2012). They include favourable contextual factors, access to technical expertise, vision, goals and objectives which are clearly defined, supported and updated when necessary, processes which are accepted by all network members, adequate resourcing and community involvement. With HEPA Europe, all these elements are present. As the network has not been "commissioned" by any national or international institution, but has grown out of the initiative of concerned experts, technical expertise and community involvement are built into it. However, fund-raising remains a challenge. In this context, high visibility products have become an additional success factor. Overall, in its different activities HEPA Europe shows characteristics of all three types of inter-organisational networks (Broesskamp-Stone, 2012): obligational, promotional and systemic.

In the European region of 2014, the role of physical activity for health is increasingly recognised not only within public health, but also in the sport sector, and important developments are underway regarding population wide physical activity promotion. Accordingly the demand for evidence-based know-how has grown, as has competition in the field, but no other institution currently has the same profile as HEPA Europe (Kahlmeier et al., 2014). To meet these growing and changing expectations, the network will have to continue evolving. Close and systematic exchange with its members and other stakeholders is essential for this purpose,

Table 3: Annual meetings and conferences of HEPA Europe. The first annual meeting in 2005 was attended by 24 participants. Numbers have steadily increased and ranged between 150 and 230 since 2008.

\begin{tabular}{|c|c|c|c|c|}
\hline Year & City & Country & Hosting institution & Events \\
\hline 2005 & Gerlev & Denmark & Gerlev Sports Academy, Slagelse & Annual meeting \\
\hline 2006 & Tampere & Finland & UKK Institute for Health Promotion Research & Annual meeting \\
\hline 2007 & Graz & Austria & University of Graz, Institute for Sports Sciences & Annual meeting \\
\hline 2008 & Glasgow & United Kingdom & $\begin{array}{l}\text { Strathclyde University, SPARColl - Scottish Physical } \\
\text { Activity Research Collaboration }\end{array}$ & $\begin{array}{l}\text { Annual meeting } \\
\text { and conference }\end{array}$ \\
\hline 2009 & Bologna & Italy & Public Health Service, Emilia-Romagna Region & $\begin{array}{l}\text { Annual meeting } \\
\text { and symposium }\end{array}$ \\
\hline 2010 & Olomouc & Czech Republic & Palacký University, Faculty of Physical Culture & $\begin{array}{l}\text { Annual meeting } \\
\text { and conference }\end{array}$ \\
\hline 2011 & Amsterdam & The Netherlands & Netherlands Institute of Sport and Physical Activity (NISB) & $\begin{array}{l}\text { Annual meeting } \\
\text { and conference }\end{array}$ \\
\hline 2012 & Cardiff & United Kingdom & $\begin{array}{l}\text { Physical Activity and Nutrition Network Wales, Public } \\
\text { Health Wales }\end{array}$ & $\begin{array}{l}\text { Annual meeting } \\
\text { and symposium }\end{array}$ \\
\hline 2013 & Helsinki & Finland & $\begin{array}{l}\text { Fit for Life Program KKI/UKK Institute for Health } \\
\text { Promotion Research }\end{array}$ & $\begin{array}{l}\text { Aannual meeting } \\
\text { and conference }\end{array}$ \\
\hline 2014 & Zurich & Switzerland & $\begin{array}{l}\text { University of Zurich, Institute of Social and Preventive } \\
\text { Medicine }\end{array}$ & $\begin{array}{l}\text { Annual meeting } \\
\text { and conference }\end{array}$ \\
\hline
\end{tabular}


as flexibility in its structures and new elements such as the communication strategy currently under development. The generation of HEPA Europe pioneers will have to be replaced by committed individuals in the steering committee and in the working groups of the network, but also in its partner organisations. Priorities within HEPA Europe's member institutions will continue to change and evolve, so funding and other forms of institutional support will have to be secured from current as well as from new members and partners.

\section{Acknowledgements}

The authors wish to thank all the individuals and institutions which have supported HEPA Europe. The views expressed are solely the authors' and do not necessarily relect those of the World Health Organization.

\section{Corresponding author:}

Eva Martin-Diener, Institute of Social and Preventive Medicine, University of Zurich, Hirschengraben 84, CH-8001 Zürich, Phone +41 44634 5001, E-Mail: eva.martin@ifspm.uzh.ch

\section{References}

Branca F., Nikogosian H., Lobstein T. (eds, 2007): The challenge of obesity in the WHO European Region and the strategies for response. WHO Regional Office for Europe, Copenhagen.

Broesskamp-Stone U. (2012): Systeme und Strukturen der Gesundheitsförderung und Prävention - internationale Perspektive. In Schwartz F.W., Walter U., Siegrist J., Kolip P., Leidl R., Dierks M.L., Busse R., Schneider N. (Hrsg.). Public Health. Gesundheit und Gesundheitswesen. 3. völlig neu bearbeitete und erweiterte Auflage. Urban und Fischer, München.

Brownson R.C., Fielding J.E., Maylahn C.M. (2009): Evidence-based public health: a fundamental concept for public health practice. Annu Rev Public Health 30: 175-201.

Bull F., Milton K., Kahlmeier S. (2014): National policy on physical activity: the development of a policy audit tool (PAT). J. Phys. Act. Health 11 (2) 233-40.

EU (2008): EU Physical Activity Guidelines. Recommended Policy Actions in Support of Health-Enhancing Physical Activity. Approved by the EU Working Group "Sport \& Health" at its meeting on 25 September 2008 Confirmed by EU Member State Sport Ministers at their meeting in Biarritz on 27-28 November 2008. European Union, Brussels.

EU Council (2013): Council recommendation on promoting health-enhancing physical activity across sectors. Interinstitutional File: 2013/0291 (NLE). Council of the European Union, Brussels.

GAPA (2010): The Toronto Charter for Physical Activity: A Global Call to Action. Global Advocacy Council for Physical Activity GAPA, International Society for Physical Activity and Health ISPAH (www.globalpa.org.uk). Institute of Medicine (1988): The Future of Public Health. National Academy Press, Washington DC.

Kahlmeier S., Popp C., Martin B.W., Backovic-Jurican A., Banzer W., Berggren F., Engelsman E., Foster C., Koornneef M., Oppert J.M., Racioppi F., Rutter H., Slachta R., Vasankari T., van Mechelen W. (2014): A systematic overview of institutions and bodies active in physical activity promotion in Europe. Schweiz. Z. Sportmed. Sporttraumatol. 62 (2): 13-18.
Kokko S., Koski P., Savola J., Alen M., Oja P. (eds.) (2009): The Report: The guidelines for Sports Club for Health (SCFORH) Programs. The Association For International Sport for All, HEPA Europe and Finnish Sport for All Association, Helsinki.

Martin B., Martin-Diener E., Balandraux-Olivet M., Mäder U., Ulrich U. (2004): Transnational Project and Workshop Series of Austria, France, Malta, the Netherlands, Sweden and Switzerland. Transport-Related Health Effects with a Particular Focus on Children. Towards an Integrated Assessment of their Costs and Benefits. State of the Art Knowledge, Methodological Asprects and Policy Directions. Topic Report Physical Activity. Federal Office of Sport and Federal Office of Public Health, Magglingen and Bern.

Martin B.W. (2014): Health-enhancing physical activity in Europe and in Switzerland: the health care setting and beyond. Schweiz. Z. Sportmed. Sporttraumatol. 62 (2): 4-5.

Martin B.W., Kahlmeier S. (2014): Physical activity and health at the population level - the role of international networks. Res. Exerc. Epidemiol. 16 (1): 1-8 (http://jaee.umin.jp/en_REE.html).

Martin B.W., Kahlmeier S., Racioppi F., Berggren F., Miettinen M., Oppert J.M., Rutter H., Šlachta R., van Poppel M., Maucec Zakotnik J., Meusel D., Oja P., Sjöström M. (2006): Evidence-based physical activity promotion HEPA Europe, the European Network for the Promotion of Health-Enhancing Physical Activity. Journal of Public Health 14 (2): 53-57.

Oja P., Bull F., Fogelhom M., Martin B.W. (2010): Physical activity recommendations for health: what should Europe do? BMC Public Health: 10: 10 doi: 10.1186/1471-2458-10-10.

Rutter H., Cavill N., Racioppi F., Dinsdale H., Oja P., Kahlmeier S. (2013): Developing a tool for estimating the economic impact of reduced mortality due to increased cycling: the Health Economic Appraisal Tool (HEAT) for Cycling. Am. J. Prev. Med. 44: 89-92.

Schmid T.L., Pratt M., Witmer L. (2006): A framework for physical activity policy research. J. Phys. Act. Health 3: 20-29.

US Department of Health and Human Services (1996): Physical activity and health: a report of the Surgeon General. US Department of Health and Human Services, Centers for Disease Control and Prevention, National Center for Chronic Disease Prevention and Health Promotion, and The President's Council on Physical Fitness and Sports, Washington and Atlanta.

Vuillemin A., Kahlmeier S., van Mechelen W., Racioppi F., Vasankari T. and the HEPA Europe Steering Committee (2014): [HEPA Europe - The European network for the promotion of health-enhancing physical activity]. Russian J. Prev. Medicine, 7 (1): 31-36.

WHO (2004): Global Strategy on Diet, Physical Activity and Health. World Health Organization, Geneva.

WHO (2006a): Physical activity and health in Europe: evidence for action. Copenhagen. WHO Regional Office for Europe, Copenhagen.

WHO (2006b): European Charter on Counteracting Obesity. WHO Regional Office for Europe, Copenhagen.

WHO (2009): $4^{\text {th }}$ annual meeting of HEPA Europe, European network for the promotion of health-enhancing physical activity. Report of a WHO meeting, 10 September 2008, Glasgow, United Kingdom. WHO Regional Office for Europe, Copenhagen, p. 12.

WHO (2012): Seventh annual meeting of HEPA Europe, European network for the promotion of health-enhancing physical activity. Report of a WHO meeting, 12-13 October 2011, Amsterdam, the Netherlands. WHO Regional Office for Europe, Copenhagen, p. 16.

WHO (2013a): Vienna declaration on nutrition and non-communicable diseases in the context of health 2020. WHO Regional Office for Europe, Copenhagen.

WHO (2013b): Physical activity promotion in socially disadvantaged groups: principles for action. PHAN Work Package 4 Final Report. WHO Regional Office for Europe, Copenhagen.

WHO (2014): Ninth annual meeting of HEPA Europe, European network for the promotion of health-enhancing physical activity. Report of a WHO meeting, 23-24 October 2013, Helsinki, Finland. WHO Regional Office for Europe, Copenhagen. 


\section{A systematic overview of institutions and bodies active in physical activity promotion in Europe}

Sonja Kahlmeier ${ }^{1}$, Christine Popp ${ }^{1}$, Brian W. Martin ${ }^{1}$, Andrea Backovic-Jurican ${ }^{2}$, Winfried Banzer 3 , Finn Berggren ${ }^{4}$, Eddie L. Engelsman ${ }^{5}$, Charlie Foster ${ }^{6}$, Marteen Koornneef ${ }^{7}$, Jean-Michel Oppert ${ }^{8}$, Racioppi F. ${ }^{9}$, Harry Rutter ${ }^{10}$, Radim SSlachta ${ }^{11}$, Tommi Vasankari ${ }^{12}$, Willem van Mechelen ${ }^{13}$

${ }^{1}$ Physical Activity and Health Unit, Institute of Social and Preventive Medicine, University of Zurich, Switzerland

${ }^{2}$ National Institute of Public Health, Ljubljana, Slovenia

${ }^{3}$ Olympics Sports Confederation, Frankfurt, Germany

${ }^{4}$ Gerlev Physical Education and Sports Academy, Gerlev, Denmark

${ }_{6}^{5}$ Netherlands Institute for Sport and Physical Activity (NISB), the Netherlands

${ }^{6}$ British Heart Foundation (BHF) Health Promotion Research Group, Oxford, United Kingdom

${ }^{7}$ Ministry of Health, Welfare and Sport, The Hague, the Netherlands

${ }^{8}$ Pierre et Marie Curie-Paris 6 University, Pitié-Salpetriere Hospital (AP-HP), Paris, France

${ }^{9}$ WHO Regional Office for Europe

${ }^{10}$ National Obesity Observatory England, Oxford, United Kingdom

${ }^{11}$ Faculty of Physical Culture, Palacký University, Olomouc, Czech Republic

12 UKK Institute for Health Promotion Research \& National Institute of Health and Welfare, Tampere, Finland

${ }^{13}$ EMGO + Institute, VU University Medical Centre, Amsterdam, the Netherlands

\begin{abstract}
Objectives: Growing interest in physical activity has led to the development of a number of organizations, networks and associations, including grass-root, professional and academic institutions. To maximize relevance and effectiveness of work undertaken in this field, we aimed at developing a systematic overview of institutions active in health-enhancing physical activity (HEPA).

Methods: Systematic, purposive weblink-search complemented by expert input; classification by institutional type, main activity and synergy with goals of HEPA Europe, the European network for the promotion of HEPA.

Results: Of 127 identified institutions, 42 met the criteria of being European and active in physical activity promotion. $45.3 \%$ were NGO/associations, $33.3 \%$ were networks, $11.9 \%$ WHO units or platforms and $9.5 \%$ bodies of the European Commission. Sport was the main topic of $28.6 \%$ institutions. Health promotion was represented with $21.4 \%$, physical activity promotion and transport/environment with $19.0 \%$ each, disease prevention with $7.2 \%$ and nutrition with $4.8 \%$. Seven institutions had a high synergy to HEPA Europe's goals. Conclusions: The search identified many institutions, networks and initiatives, which 1 . reflects the growing interest in and importance of physical activity for a number of stakeholders, 2. provides increased capacity to address this important topic on a European scale and 3. creates a "critical mass" to push the agenda forward into clearer and synergetic directions. Systematically mapping key players is a useful tool for institutions active in an environment with a multitude of actors to ensure that activities provide added value, to avoid duplication and to promote partnership and efficient use of resources.
\end{abstract}

Keywords: Physical activity, sport, public health, institutions, Europe

\section{Zusammenfassung}

Ziele: Die Anzahl der Institutionen, die sich auf verschiedenen Ebenen mit dem Thema Bewegung auseinandersetzen, hat deutlich zugenommen. Um die Wirksamkeit seiner eigenen Aktivitäten steigern zu können, hat HEPA Europe, das Europäische Netzwerk für Bewegungsförderung, einen systematischen Überblick über diese Institutionen erarbeitet.

Methoden: Systematische, zielgerichtete Weblink-Suche und Experteninput. Klassifizierung nach Art der Institution, Hauptaktivität und Synergien mit den Zielen von HEPA Europe. Resultate: Von 127 identifizierten Institutionen entsprachen 42 den Einschlusskriterien, in Europa aktiv zu sein und spezifische Bewegungsförderungsaktivitäten $\mathrm{zu}$ haben. $45.3 \%$ waren Nichtregierungsorganisationen oder Verbände, 33.3\% Netzwerke, 11.9\% Abteilungen oder Plattformen der Weltgesundheitsorganisation WHO und 9.5\% Gremien der Europäischen Kommission. Sport war bei $28.6 \%$ die Hauptaktivität. Gesundheitsförderung war mit $21.4 \%$ vertreten, Bewegungsförderung und Transport oder Umwelt mit je $19.0 \%$, Prävention mit $7.2 \%$ und Ernährung mit 4.8\%. Sieben Institutionen wiesen starke Synergien mit den Zielen von HEPA Europe auf.

Schlussfolgerungen: Es wurden viele Institutionen identifiziert, was 1. zunehmendes Interesse und Bedeutung des Themas Bewegung aufzeigt, 2. eine Zunahme der vorhandenen Fachkompetenz darstellt, und 3. eine «kritische Masse» ergibt, um die Anliegen gemeinsam und gezielt voranzutreiben. Das systematische Abbilden von Organisationen ist ein nützliches Instrument für Institutionen, die in einem Umfeld mit vielen Akteuren tätig sind, um sicherzustellen, dass ihre Aktivitäten zusätzlichen Nutzen bringen, um Doppelspurigkeiten zu vermeiden und um Partnerschaften und optimale Nutzung der vorhandenen Mittel zu fördern.

Schlüsselwörter: Physical activity, sport, public health, institutions, Europe 


\section{Introduction}

Over the past few years, growing interest of public health and policy makers in physical activity (WHO 2004; GAPA 2010; WHO 2011) has led to the development of a number of organizations, networks and associations, covering the range from grass-root to professional and academic institutions. This has resulted in a highly dynamic and thriving community, stronger advocacy and more capacities to promote physical activity, but at the same time has increased the challenge to avoid duplication of efforts and to direct advocacy efforts in synergic and coherent directions.

Therefore, there is a strong interest in developing a methodology which allows collating a comprehensive map of relevant institutions as a means to "networking the networks", promoting synergy and partnership with relevant players and ensuring that available resources are used efficiently.

An attempt in this direction has been made within the framework of HEPA Europe, the European Network for the promotion of Health-Enhancing Physical Activity (HEPA), founded in 2005, whose vision is to achieve better health through physical activity among all people in Europe (Martin-Diener et al. 2014; www.euro.who.int/hepa). The network is dedicated to strengthening and supporting efforts and actions that increase participation and improve the conditions favorable to a healthy lifestyle, in particular with respect to health-enhancing physical activity. HEPA Europe is also committed to maximizing its relevance and added value to its members and stakeholders, as well as to sharpen its communication and further developing its strategic partnerships.

This article presents a systematic overview of institutions active in the field of physical activity promotion in Europe. The analysis was undertaken to maximize relevance and effectiveness of work undertaken in this field by identifying the different scopes and areas covered as well as gaps and possibilities for synergies. The results were applied to HEPA Europe as a case study. The approach is of general interest to those active in fields with multiple players, such as networking or advocacy on different aspects of public health or sport science.

\section{Methods}

An initial list of institutions active in the field of healthenhancing physical activity compiled based on available knowledge served as a basis for developing a more detailed list. To identify further institutions, a systematic purposive weblink-search was carried out, using inclusion criteria. The websites of institutions on the initial list were searched for links to other institutions, adding further institutions to the list subsequently. The process was continued until no further relevant institutions were identified among the link web-sections of new institutions.

Private and public institutions with the following characteristics were included:

- European in scope

- clearly identifiable current activities related to promoting physical activity

- body, institution or policy platform

Projects or processes (i.e. publications, time-limited projects and activities) were not included.

The preliminary list was discussed and amended in meetings of the Steering Committee of HEPA Europe in April and
September 2010. The final draft was disseminated for input to all member institutions of HEPA Europe as well as to the participants of its 2 nd conference and $6^{\text {th }}$ annual meeting in November 2010. Institutions were considered for the overview until February 2011.

The institutions meeting the inclusion criteria were recorded in an overview table. Information was extracted on the following items:

- Type of institution

According to the information on the website and expert input, the institutions were classified as "Network", "EC body", "WHO units \& platforms", or "NGO/Association" (also including councils, federations, committees).

- Topic

The institution's main domain was categorized as: physical activity promotion; sport (including promotion, science, education, management, platforms); health promotion; disease prevention (such as cardiovascular diseases, obesity, etc.); nutrition; transport or environment

- Mission

Mission or goals stated on the website of the institution were summarized with a special focus on identifying physical activity-related aspects.

- Members

Where stated, the number of members was noted.

- Affiliations

If an institution was found to be closely related to or being part of another institution, the connection was recorded.

- Activities

The main work focus of the institution was categorized into "research", "promotion”, "intervention", "policy”, "knowledge" (knowledge transfer/dissemination, including education). Additionally, projects initiated, guides developed or meetings organized by the institution were listed if identified as part of the web search.

- Synergy with goals of HEPA Europe

The synergy of the institution's work with the goals of HEPA Europe was rated on a scale ranging from 1=high to $2=$ intermediate and $3=$ limited. The following qualitative approach was used for this rating: the more activities on promoting health-enhancing physical activity (rather than e.g. elite sport), the higher the synergy with HEPA Europe; the more public health-related rather than disease focused, the closer the objectives. A preliminary rating was discussed and amended in the Steering Committee meetings.

\section{Results}

In total, 127 institutions and bodies were identified. Of those, 42 institutions and bodies $(33.1 \%)$ met the inclusion criteria and were added to the overview list. Not included were 16 global institutions (12.6\%), 7 medical associations (5.5\%) and 62 bodies $(48.8 \%)$ for other reasons (e.g. only mentioning physical activity in general but no specific activities).

Table 1 shows the 42 institutions in alphabetical order and classified according to type, topic, synergy with goals of HEPA Europe, and main activity.

Nineteen institutions (45.3\%) were NGO/associations, while $14(33.3 \%)$ were networks, $5(11.9 \%)$ WHO units or platforms, and $4(9.5 \%)$ bodies of the European Commission (EC). Sport was the main topic of $12(28.6 \%)$ institutions, health promotion was represented with 9 bodies (21.4\%), 
Table 1: European institutions active in physical activity promotion, by type, topic, synergy with goals of HEPA Europe, main activity and number of member organizations including countries represented

\begin{tabular}{|c|c|c|c|c|c|}
\hline Name & Type & Topic & \begin{tabular}{|l} 
Synergy \\
with goals \\
of HEPA \\
Europe* \\
\end{tabular} & $\begin{array}{l}\text { Main } \\
\text { activity }\end{array}$ & \begin{tabular}{|l|} 
Member \\
organisations \\
(countries)
\end{tabular} \\
\hline ACES (European Capitals of Sport Association) & NGO/Association & Sport & 2 & Promotion & n.a. \\
\hline CEHAPE (Children's Environment and Health Action Plan) & WHO unit/platform & HP & 1 & Promotion & n.a. \\
\hline CESS (Confédération Européenne Sport et Santé) & NGO/Association & PAP & 1 & Promotion & $32(17)$ \\
\hline Council of Europe/Sport Unit & NGO/Association & Sport & 3 & Policy & $(47)$ \\
\hline DG EAC (DG for Education and Culture), Sport Unit & EC body & Sport & 2 & Policy & n.a. \\
\hline DG SANCO (Directorate General for Health and Consumers) & EC body & HP & 2 & Policy & n.a. \\
\hline $\begin{array}{l}\text { EACPR (European Association for Cardiovascular Prevention } \\
\text { \& Rehabilitation) }\end{array}$ & NGO/Association & DP & 3 & Knowledge & (53) \\
\hline ECF (European Cyclists' Federation) & NGO/Association & TE & 2 & Promotion & $65(39)$ \\
\hline ECSS (European College of Sports Science) & NGO/Association & Sport & 2 & Research & n.a. \\
\hline EEN (Epode European Network) & Network & DP & 3 & Promotion & n.a. \\
\hline EFCS (European Federation for Company Sports) & NGO/Association & Sport & 3 & Promotion & $(30)$ \\
\hline $\begin{array}{l}\text { EGREPA (European Group for Research into Elderly } \\
\text { and Physical Activity) }\end{array}$ & NGO/Association & PAP & 3 & Research & n.a. \\
\hline EGWA (European Greenways Association) & NGO/Association & $\mathrm{TE}$ & 2 & Promotion & n.a. \\
\hline EHFA (European Health and Fitness Association) & NGO/Association & PAP & 2 & Promotion & $18(23)$ \\
\hline EHN (European Heart Network) & Network & DP & 3 & Policy & $(26)$ \\
\hline ELSN (Euro Local Sport Network) & Network & PAP & 1 & Knowledge & n.a. \\
\hline ENGSO (European Non-Governmental Sports Organisation) & NGO/Association & Sport & 2 & Policy & 40 \\
\hline $\begin{array}{l}\text { ENSSEE (European Network of Sport Science, Education } \\
\text { and Employment) }\end{array}$ & Network & Sport & 3 & Knowledge & 45 \\
\hline ENWHP (European Network for Workplace Health Promotion) & Network & HP & 2 & Promotion & $(28)$ \\
\hline EOC (European Olympic Committee) & NGO/Association & Sport & 3 & Knowledge & n.a. \\
\hline EPHA (European Public Health Alliance) & NGO/Association & HP & 3 & Policy & 100 \\
\hline ESFAN (European Sport for All Network) & Network & PAP & 1 & Promotion & $25(22)$ \\
\hline EU working group on sports and health & EC body & Sport & 2 & Policy & n.a. \\
\hline EUFAPA (European Federation of Adapted Physical Activity) & NGO/Association & Sport & 3 & Knowledge & n.a. \\
\hline EUFIC (European Food Information Council) & NGO/Association & Nutrition & 3 & Knowledge & n.a. \\
\hline $\begin{array}{l}\text { EUNAAPA (European Network for Action on Ageing } \\
\text { and Physical Activity) }\end{array}$ & Network & PAP & 2 & Promotion & n.a. \\
\hline EUPEA (European Physical Education Association) & NGO/Association & PAP & 2 & Promotion & $(32)$ \\
\hline EUPHA (European Public Health Association) & NGO/Association & HP & 3 & Knowledge & $72(42)$ \\
\hline Eurocities & Network & TE & 3 & Intervention & $140(30)$ \\
\hline EuroHealthNet & Network & HP & 3 & Knowledge & $33(26)$ \\
\hline European Platform for Action on Diet, Physical Activity \& Health & Network & PAP & 1 & Intervention & 33 \\
\hline $\begin{array}{l}\text { EUROPREV (European Network for Prevention and } \\
\text { Health Promotion in Family Medicine \& General Practice) }\end{array}$ & Network & HP & 3 & Knowledge & n.a. \\
\hline EWS (European Women and Sport) & NGO/Association & Sport & 3 & Promotion & (41) \\
\hline FEPA (Federation of European Pedestrian Associations) & NGO/Association & TE & 2 & Promotion & 9 \\
\hline High Level Group on Nutrition and Physical Activity & EC body & Nutrition & 2 & Policy & n.a. \\
\hline $\begin{array}{l}\text { POLIS (European Cities \& Regions } \\
\text { Networking for Innovative Transport Solutions) }\end{array}$ & Network & $\mathrm{TE}$ & 3 & Knowledge & n.a. \\
\hline Regions for Health Network & WHO unit/platform & $\mathrm{TE}$ & 3 & Knowledge & $29(18)$ \\
\hline SHE (Schools for Health in Europe) & Network & HP & 2 & Policy & $(43)$ \\
\hline $\begin{array}{l}\text { THE PEP (Transport, Health and Environment } \\
\text { Pan-European Programme) }\end{array}$ & WHO unit/platform & TE & 1 & Policy & n.a. \\
\hline THENAPA II (Thematic Network Adapted Physical Activity) & Network & Sport & 3 & Knowledge & $(27)$ \\
\hline WHO/Europe Healthy Cities & WHO unit/platform & TE & 2 & Intervention & $1400(30)$ \\
\hline WHO/Europe Lifestyle determinants / health \& environment & WHO unit/platform & HP & 1 & Policy & n.a. \\
\hline
\end{tabular}

Abbreviations: NGO: Non-Governmental Organisation; EC: European Commission; WHO: World Health Organization; HP: Health Promotion;

PAP: Physical Activity Promotion; DP: Disease Prevention; TE: Transport \& Environment; n.a. not available

* Synergy with the goals of HEPA Europe $1=$ high, 2 = intermediate, 3 = limited 
physical activity promotion and transport/environment with 8 each (19.0\%), disease prevention with $3(7.2 \%)$, and nutrition with $2(4.8 \%)$.

The main activity of 14 institutions $(33.3 \%)$ could be described as mostly promotion-related, of $12(28.6 \%)$ as knowledge transfer, of $11(26.2 \%)$ as policy making, of 3 (7.1\%) as intervention-related and of $2(4.8 \%)$ as research.

Where available, the number of member organizations and the number of countries represented by an institution were listed as well. They ranged from 9 to 1400 member organizations, and from 17 to 47 countries represented per institution, but information was incomplete on this item.

Figure 1 shows the 42 institutions in three circles according to their rated synergy with the goals of HEPA Europe, and separated into the 6 topical sectors and the 4 types of institutions.

The activities of 7 institutions $(16.7 \%)$ were rated as very closely related to the scope and work of HEPA Europe. Four of them $(9.6 \%)$ work on physical activity promotion, $2(4.8 \%)$ on health promotion and $1(2.4 \%)$ on transport/environment. Three $(7.2 \%)$ are WHO units or platforms, 3 (7.2\%) networks and $1(2.3 \%)$ an NGO/association. Sixteen (38.1\%) institutions were found to share intermediate synergy with the goals of HEPA Europe, 19 (45.2\%) with limited synergy.

In addition to the European bodies, among the originally found 127 institutions 14 bodies with non-European or global scope were identified that are also relevant for the European context, including:

- Agita Mundo, the global physical activity network

- American College of Sports Medicine (ACSM)

- Centers for Disease Control and Prevention (CDC) / WHO collaborating Center on Physical Activity and Health

- International Council of Sport Science and Physical Education (ICSSPE)

- International Institute for Health Promotion (IIHP)

- International Olympic Committee (IOC)

- International Physical Activity and the Environment Network (IPEN)

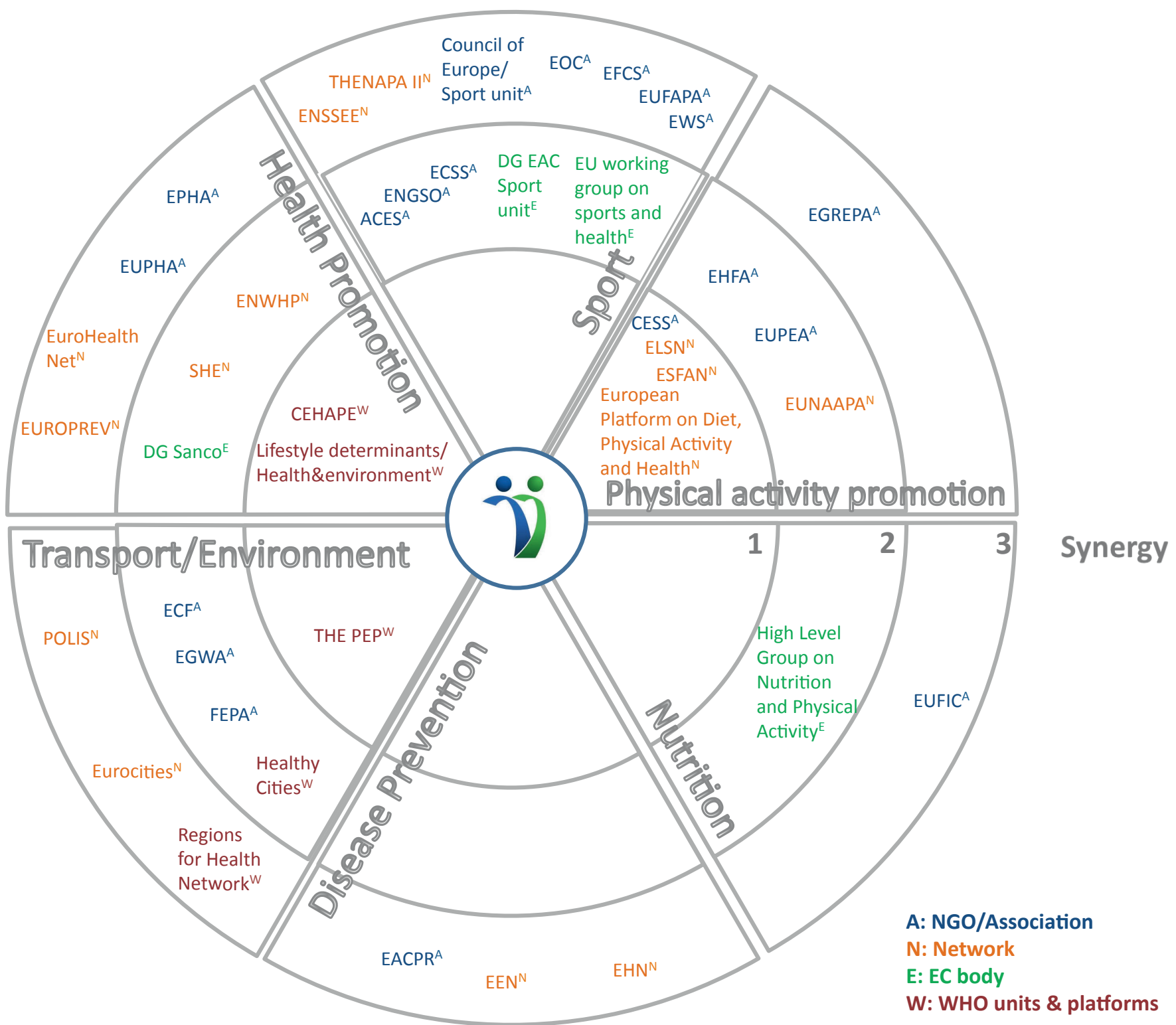

Figure 1: European institutions promoting physical activity (by topic, type and synergy with goals of HEPA Europe). See table 1 for abbreviations. Synergy with goals of HEPA Europe: $1=$ high; $2=$ intermediate; $3=$ limited. 
- International Society for Behavioral Nutrition and Physical Activity (ISBNPA)

- International Society for Physical Activity and Health (ISPAH) \& GAPA (Global Advocacy for Physical Activity), the Advocacy Council of ISPAH

- International Sport and Culture Association (ISCA)

- International Union for Health Promotion and Education (IUHPE)

- SportAccord (International Federations' Union, both Olympic and non-Olympic sports)

- The Association For International Sport for All (TAFISA)

HEPA Europe is also in close contact with three other regional HEPA promotion networks:

- AFPAN (African Physical Activity Network)

- APPAN (Asia Pacific Physical Activity Network)

- RAFA/PANA (Red de Actividad Fisica de las Americas).

\section{Discussion}

Investments into developing an evidence-based understanding of the environment in which an institution is operating can greatly support the development of a more strategic approach (Nutbeam 2006). Identification of partners can facilitate a more efficient use of resources by avoiding duplication of efforts while at the same time creating a "critical mass" of knowledge and advocacy power that can help pushing forward the agenda into clearer and synergetic directions. To our knowledge, no similar systematic overview of institutions active in the field of physical activity promotion has been developed so far. The search revealed the existence of many institutions, which displays an increasing capacity to address this important topic on a European scale and also emphasizes the importance of the points mentioned above.

For HEPA Europe, the approach confirmed its scope to be appropriate and unique in Europe, with no other institution positioned identically. Collaboration or exchange is taking place already with five of the seven very closely related bodies and with about two thirds of the intermediately close institutions, in accordance with one of HEPA Europe's stated objectives to improve coordination in physical activity promotion across sectors and administrative structure, together with other relevant institutions and organizations (Martin-Diener et al., 2014).

Defining a European scope and specific physical activity related activities as inclusion criteria led to the exclusion of two-thirds of the 127 found institutions. About one third of the institutions active in Europe in the field of physical activity promotion focus mainly on promotion, while about $20 \%$ are more active in knowledge transfer or policy making, respectively. This seems to represent a good degree of diversity of key areas of activity. Research, listed only twice as main activity, is naturally done more by local institutions not accounted for in this overview, such as universities.

Of the 23 institutions with information on membership numbers, provenance of members was from at least 17 countries, thereby having the size to perform promotion, knowledge exchange and policy development with European reach.

By conducting a simplified overview, not all the properties of the institutions could be taken into account, which made it difficult in some cases to assign an institution clearly to one category or another. However, the topic most often addressed according to the information on the websites was sport. But the distinction between physical activity and sport still often seems to be more of a semantic nature rather than an actual topical one, as also found in a recent analysis of European sport policies (Christiansen, Kahlmeier and Racioppi 2012). About $20 \%$ of the identified institutions are active in transport and/ or environment which can be seen as encouraging in view of the need for intersectoral approaches to address the challenge to reduce inactivity in Europe and globally (WHO 2007; GAPA 2010; WHO 2010; GAPA 2011). Seven European medical associations were also identified as potentially relevant. However, no detailed information on current activities on physical activity promotion was available. As examples such as the development of physical activity recommendations show, in some countries (para-)medical associations have taken a leading role in this field (Haskell et al., 2007; Canadian Society for Exercise Physiology 2011). Another limitation may be that some organizations were not captured by the search methods; possible reviewer or selection bias was limited through the involvement and repeated discussion of results with a range of experts.

In summary, the overview placing institutions according to topic, type and synergy with HEPA Europe's goals provides a useful picture of the current landscape of institutions, facilitating at the same time the positioning of an institution such as HEPA Europe among other bodies and institutions in Europe active in physical activity promotion. This will be a valuable basis for its communication strategy. The methodology in developing this overview may serve as an input for other institutions seeking to position themselves in a field with multiple players, for example in public health or sport science.

\section{Acknowledgements}

We wish to thank Ms. Claudia Frangella, University of Rome, Italy, for contributing to the initial web-search to identify institutions as part of an internship at WHO Regional Office for Europe, European Centre for Environment and Health, Rome, Italy. Funding: This study was co-financed by a grant of the WHO Regional Office for Europe. The views expressed are solely the authors' and do not necessarily reflect those of the World Health Organization.

\section{Corresponding author:}

Sonja Kahlmeier, Physical Activity and Health Unit, Institute of Social and Preventive Medicine, Seilergraben 49, 8001 Zurich, Switzerland, E-Mail: sonja.kahlmeier@uzh.ch, Phone +41 446344 371, Fax +41 446345185

\section{References}

Canadian Society for Exercise Physiology (2011): Canadian Physical Activity Guidelines. Accessed 14.05.14, from http://www.csep.ca/english/view. asp? $\mathrm{x}=804$.

Christiansen N., Kahlmeier S. and Racioppi F: (2014): Sport promotion policies in the European Union: results of a contents analysis. Scand. J. Med. Sci. Sports 24 (2): 428-438.

GAPA (2010): The Toronto Charter for Physical Activity: A Global Call to Action. Global Advocacy Council for Physical Activity GAPA, International Society for Physical Activity and Health ISPAH (www.globalpa.org.uk).

GAPA (2011): Non communicable disease prevnetion: Investments that work for physical activity. Global Advocacy Council for Physical Activity GAPA, International Society for Physical Activity and Health ISPAH (www.globalpa. org.uk).

Haskell W.L., Lee I.M., Pate R.R., Powell K.E., Blair S.N., Franklin B.A., Macera C.A., Heath G.W., Thompson P.D. and Bauman A. (2007): Physical 
activity and public health: updated recommendation for adults from the American College of Sports Medicine and the American Heart Association. Med. Sci. Sports Exerc. 39(8): 1423-1434.

Martin B., Kahlmeier S., Racioppi F., Berggren F., Miettinen M., Oppert J.-M., Rutter H., Slachta R., van Poppel M., Zakotnik J., Meusel D., Oja P. Sjöström M. (2006): Evidence-based physical activity promotion - HEPA Europe, the European Network for the Promotion of Health-Enhancing Physical Activity. J. Public Health 14: 53-57.

Martin-Diener E., Sonja S., Vuillemin A., van Mechelen W., Vasankari T., Racioppi F., Martin B. (2014): 10 years of HEPA Europe: what made it possible and what is the way into the future? Schweiz. Z. Sportmed. Sporttraumatol. 62 (2): 6-12.
Nutbeam D. and Bauman A. (2006): Evaluation in a Nutshell. McGraw-Hill, Sydney.

WHO (2007): Steps to health - A European framework to promote physical activity for health. WHO Regional Office for Europe, Copenhagen.

WHO (2004): Global Strategy on Diet, Physical Activity and Health. World Health Organization, Geneva.

WHO (2010): Global Recommendations on Physical Activity for Health. World Health Organization, Geneva.

WHO (2011): Action plan for implementation of the European Strategy for the Prevention and Control of Noncommunicable Diseases 2012-2016. WHO Regional Office for Europe, Copenhagen. 


\title{
Physical activity promotion in the health care setting in Switzerland
}

\author{
Brian W. Martin ${ }^{1}$, Oliver Padlina ${ }^{2}$, Eva Martin-Diener ${ }^{1}$, Raphael Bize ${ }^{3}$, Jacques Cornuz ${ }^{4}$, \\ Sonja Kahlmeier ${ }^{5}$ \\ ${ }^{1}$ Institute of Social and Preventive Medicine, University of Zurich \\ ${ }^{2}$ RADIX Schweizerische Gesundheitsstiftung, Zürich \\ ${ }^{3}$ Institut Universitaire de Médecine Sociale et Préventive, Lausanne \\ ${ }^{4}$ Policlinique Médicale Universitaire, Lausanne
}

\section{Summary}

The role of regular physical activity for population health has been clearly documented. Improvements in population levels of physical activity require long-term implementation of a combination of measures, including the evidence based approaches described in the "seven best investments for physical activity" (www.globalpa.org.uk): whole-of-school programmes, transport, urban planning, integration of physical activity promotion into primary health care systems, public education, community-wide programmes, sport for all. The health care setting has a particular role in this context, particularly in its access to physically inactive individuals. Switzerland has seen a number of successful research projects in this field, but there has been no wide adaptation of these approaches in the medical community. In recent years, a group of institutions including the Swiss College of Primary Care Medicine, the Policlinique Médicale Universitaire in Lausanne, the Ligue Vaudoise contre les Maladies Cardiovasculaires and the Institute of Social and Preventive Medicine of the University of Zurich have therefore focussed on the development of a physical activity counselling approach based on international evidence as well as on established tools, but streamlined to the specific demands of primary health care providers in Switzerland. PAPRICA (Physical Activity Promotion in Primary Care, www.paprica. ch) has been the result of these developments, and nearly 300 health professionals, most of them primary care physicians, have been successfully trained so far. PAPRICA is implemented together with the Swiss Society for Sports Medicine and a number of regional partners. The development of a national programme structure is currently under preparation. This will allow Switzerland to explore and better use the potential of physicians and other health professionals in the promotion of physical activity and in the fight against non-communicable diseases.

Keywords: physical activity, healthcare, counselling, chronic disease, prevention, Switzerland

\section{Zusammenfassung}

Die Rolle von regelmässiger Bewegung für die Gesundheit ist gut dokumentiert. Verbesserungen im Bewegungsverhalten auf Bevölkerungsebene können nur erreicht werden durch die langfristige Umsetzung einer Kombination von Ansätzen, die sich an den von der internationalen Gesellschaft für Bewegung und Gesundheit empfohlenen «sieben besonders erfolgsversprechenden Bewegungsförderungsmassnahmen» orientieren: Schule, Transport, Städteplanung, medizinische Grundversorgung, Öffentlichkeitsarbeit, Gemeinde- und Gemeinschaftsprogramme, Breitensport. Die medizinische Grundversorgung hat dabei eine spezielle Bedeutung, besonders im Hinblick auf den Zugang zu körperlich Inaktiven. In der Schweiz gab es eine Reihe von erfolgreichen Projekten zur Bewegungsförderung in der Arztpraxis, keines wurde aber von der Ärzteschaft breit aufgenommen. Eine Reihe von Institutionen, darunter das Schweizerische Kollegium für Hausartzmedizin, die Policlinique Médicale Universitaire in Lausanne, die Ligue Vaudoise contre les Maladies Cardiovasculaires and das Institut für Sozial- und Präventivmedizin der Universität Zürich haben deshalb die Entwicklung eines Ansatzes zur Bewegungsberatung in Angriff genommen, der auf internationalen wissenschaftlichen Erkenntnissen und bewährten Instrumenten beruht, gleichzeitig aber auf die Bedürfnisse der medizinischen Grundversorgung in der Schweiz ausgerichtet ist. PAPRICA (Physical Activity Promotion in Primary Care, www.paprica.ch) wird gemeinsam mit der Schweizerischen Gesellschaft für Sportmedizin und regionalen Umsetzungspartnern angeboten; nahezu 300 Ärztinnen und Ärzte, die meisten von ihnen Grundversorger, sind inzwischen ausgebildet worden. Zur Zeit wird eine nationale Programmstruktur für PAPRICA vorbereitet. Diese soll es erlauben, in der Schweiz das Potential der Ärzteschaft und der anderen Gesundheitsberufe in der Bewegungsförderung und im Kampf gegen die nicht-übertragbaren Krankheiten noch besser zu nutzen.

Schlüsselwörter: Physical activity, healthcare, counselling, chronic disease, prevention, Switzerland 


\section{Recommendations and levels of physical activity}

The importance of physical activity for population health is well documented, and at the global level, the impact of physical inactivity is deemed to be comparable to the one of smoking or overweight (Lee et al., 2012). Recent health policy documents at the global and the European level recognise the role of physical activity promotion in the fight against non-communicable diseases, the World Health Organisation WHO has begun with the development of a European Physical Activity Strategy in 2014 (Martin-Diener et al., 2014).

The "Core Document Health-Enhancing Physical Activity" for Switzerland is available in English, German, French and Italian. Its latest edition (FOSPO et al, 2013) follows the structure of the earlier versions of the same document (MartinDiener et Martin, 2009), but it contains updated information on the health effects of physical activity, on the levels of physical activity in the Swiss population and on the principles of physical activity promotion. For these aspects, the document relies on the Toronto Charter for Physical Activitgy Promotion (GAPA 2010) and on the "seven best investments for physical promotion" (GAPA 2011), both developed by the Global Advocacy Council for Physical Activity of the International Society for Physical Activity and Health (ISPAH). An important element of the document are also the national recommendations for health-enhancing physical activity issued in 2013 which have replaced the existing ones for adults from 1999 as well the ones for children and adolescents from 2006 (Martin et al, 2009). Additionally, there is now also a version covering specifically the age group of the elderly adults. They all are based on the first ever Global Recommendations on Physical Activity for Health issued by WHO in 2010 (WHO 2010) and have been developed in a consultative process suggested by international experts (Oja et al, 2010) and based on a comparison with other national and international documents (Kahlmeier et al., 2012). The most important difference between the 1999 and the 2013 minimal recommendations for adults is that they can be met not only by "half an hour a day on most days of the week" of moderate intensity activities, but also by other accumulations of $2 \frac{1}{2}$ hours per week or by any combination of moderate and vigorous intensity activities, using a "conversion factor" of 2 for the latter.

Switzerland still does not have any nationally representative physical activity data for adults based on internationally validated questionnaires (Martin et al., 2009), but according to the first results of the Swiss Health Survey 2012 (BFS 2012) 72\% of Swiss adults report meeting the new minimal recommendations described above, an increase of $10 \%$ compared to 2002 (figure 1). With respect to the stricter 2006 recommendations, the prevalence of inactivity was higher (Martin et al. 2009). The prevalence of adolescents meeting the respective one hour daily recommendations (FOSPO et al, 2013, WHO 2010) continues to be based on the Health Behaviour in School Children (HBSC) survey; it remained stable between $12 \%$ and $13 \%$ from 2002 to 2010 (Currie et al, 2012, figure 1).

\section{Primary care in the context of other approaches to physical activity promotion}

The scientific literature (Heath et al, 2012) and institutional recommendations (Bellew et al., 2011) have identified a whole range of effective approaches to physical activity promotion at the population level. They are summed up in the "seven best investments for physical activity" (GAPA 2011): wholeof-school programmes, transport, urban planning, integration of physical activity promotion into primary health care systems, public education, community-wide programmes, sport for all. Within this context, the health care system has a specific role because it provides access to individuals who are very difficult to reach for other approaches of physical activity promotion and because it can make use of established structures and procedures. Already in 2004, a representative survey showed that $80 \%$ of Swiss adults would appreciate it if their family physicians addressed their physical activity behaviour and for $81 \%$ of them their physician's advice on this topic was important (Bize et al., 2008). The respective numbers for physical therapists were $76 \%$ and $78 \%$ respectively, those for licensed pharmacists 40\% and 32\% (Martin et al., 2013). Good health care as such can also be an important prerequisite for physical activity behaviour, as health status has been shown consistently to be a correlate or even determinant of physical activity in adults (Bauman et al, 2012). A whole number of systematic reviews have shown the effectiveness of physical activity counselling in primary care (Orrow et al, 2012, Campbell et al, 2012) and of short counselling interventions in particular (Garrett et al., 2011, Anokye et al, 2014). The role of physicians has been well studied (Lin et al, 2010); the role of other health professionals is less clear (Tulloch et al, 2006).

\section{The PAPRICA approach}

Approaches to physical activity promotion in primary care have also been developed in Switzerland, with documentation of effectiveness for some of them. However, none of them has been widely adopted by the medical community (Bize et al., 2008). Therefore PAPRICA (Physical Activity Promotion in PRImary Care) has been developed in a multi-year and multi-partner process including the Swiss College for Primary Care Medicine, the Policlinique Médicale Universitaire in Lausanne, the Ligue Vaudoise contre les Maladies Cardiovasculaires and the Institute of Social and Preventive Medicine of the University of Zurich (Schmid et al., 2009). PAPRICA is based on international evidence as well as on established approaches and tools, but it is streamlined to the specific demands of primary care practices and has been successfully tested in both the French speaking and the German speaking part of Switzerland (Martin et al., 2013). PAPRICA's central element are short physical activity counselling interventions delivered by primary care physicians (figure 2). It offers targeted continuing education programmes, using the Thursday afternoon format established in Switzerland. These training sessions provide background knowledge, hands-on experience and counselling skills based on the motivational interviewing technique which has been successfully introduced also for other aspects of prevention and health promotion in primary care (Neuner-Jehle et al., 2009). PAPRICA uses a manual for physicians, a brochure for patients and additional counselling support. Physical activity promotion in primary care is most successful when general counselling and strategies for behavioural change can link up with local opportunities and offers for physical activity. Cooperation is also of interest for local providers of health promotion and physical activity promotion, as it enables them to extend their reach (figure 2). 


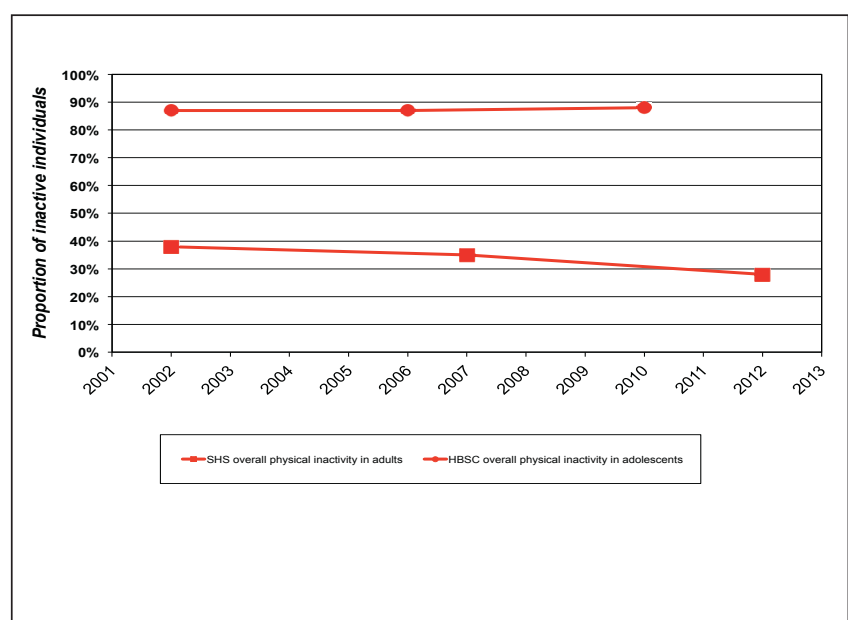

Figure 1: Best available population estimates for overall physical inactivity in Switzerland. The Swiss Health Survey (SHS) has measured leisure time physical activity in adults since 1992, from 2002 on including also data on moderate intensity activities. The proportion of adults not meeting the 2013 minimal physical activity recommendations was $38 \%$ in 2002, 35\% in 2007 and 28\% in 2012 (BFS 2013). According to the Health Behaviour in School-Aged Children Survey (HBSC), $87 \%$ of 11 to 15 year old adolescents did not meet the minimal recommendations of one hour of physical activity every day in 2002 and 2006, 88\% in 2010 (Currie et al, 2012). Details and limitations of the methodology are described elsewhere (Martin et al., 2009).

Since 2009 PAPRICA is implemented in the French speaking canton of Vaud. In collaboration with the move $>$ med Swiss Olympic Medical Center at the Balgrist University Hospital in Zurich, the training module has been adapted for the German speaking part of Switzerland. The Swiss Congress for Sports Medicine in 2012 was the national launch of PAPRICA, since then continuing education sessions are offered together with the Swiss Society for Sports Medicine (SSSM) and regional partners in a growing number of cantons. Since 2013, PAPRICA has also been integrated into the curriculum for the Certificate in Sports Medicine of the SSSM. Nearly 300 health professionals, most of them primary care physicians, have been successfully trained so far. In early 2012, an evaluation questionnaire was sent to 204 physicians trained in the French speaking part of Switzerland until then. Participation was $44 \%$ and results showed that physicians spent on average 5 minutes for the counselling intervention with their patients as originally intended, and that they rated their respective knowledge and skills as far better than before they had attended the training (Koutaissoff et al., 2012).

There have been some attempts to offer training in physical activity counselling to other professional groups in Switzerland as well. In the years 2004 to 2006, a continuing education programme using a combination of e-learning and a workshop was offered to health professionals as well as PE teachers and sport scientist. The majority of the 49 participants were physical therapists (Padlina et al, 2009). The training was rated very positively in the short term as well as in a follow-up survey in early 2006. However, it was not possible to establish funding mechanisms for the counselling activities, so training was discontinued (Martin et al., 2103).

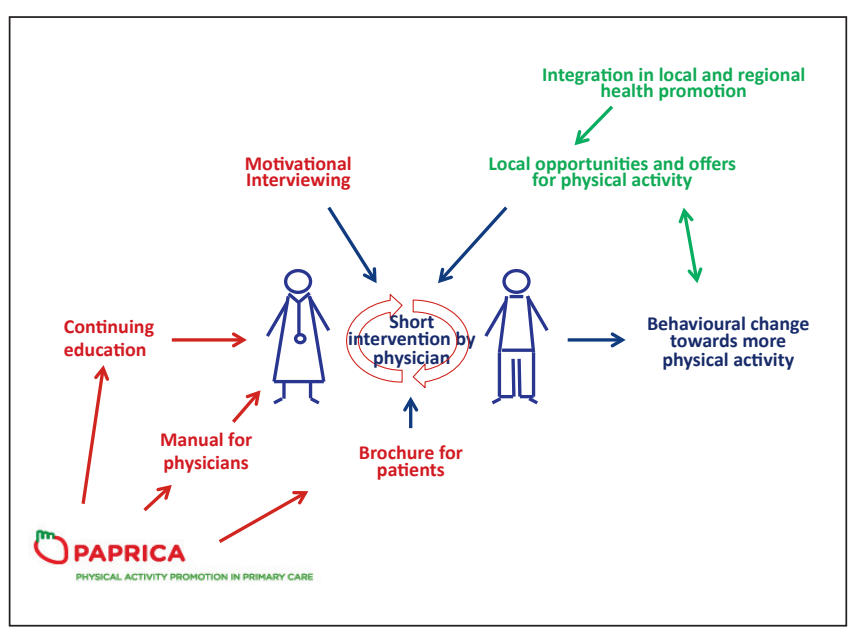

Figure 2: Principle of the PAPRICA (Physical Activity Promotion in PRImary Care) approach developed in Switzerland. Primary care physicians are trained in short counselling interventions using Motivational Interviewing techniques. They are provided with background information and communication material. Regional health promotion institutions provide information on possibilities and offers for physical activity in order to facilitate behavioural change. The website www.paprica.ch is currently available in French and in German

\section{Current developments in Switzerland}

Further progress in the fight against physical inactivity will depend on a combination of measures at different levels. The PAPRICA approach has the potential to reach individuals less amenable to other measures of physical activity promotion. Projects for its use in cardiac patients and in paediatric patients are currently underway. So are preparations for research projects and the integration of PAPRICA in the training of medical students. A pilot project is planned in the canton of Ticino, where PAPRICA will be used in the Italian language for the first time and where the potential for further synergies with the "Health Coaching" approach for multidimensional behavioural counselling of the Swiss College for Primary Care Medicine (Neuner-Jehle et al., 2013) will be explored. International exchange will remain a key element for future developments (Martin 2014).

PAPRICA has not had any national level funding for its implementation so far, but currently the development of a national programme structure is underway with support from the Federal Office of Public Health and the Swiss Cancer League. Such a structure and a dedicated budget will allow Switzerland to explore and better use the potential of physicians and other health professionals in the promotion of physical activity and in the fight against non-communicable diseases.

\section{Corresponding author:}

Brian Martin, MD MPH, University of Zurich, Institute of Social and Preventive Medicine, Physical Activity and Health Unit, Seilergraben 49, Room D-03, 8001 Zurich Switzerland, telephone +41 446344557

E-Mail: brian.martin@uzh.ch 


\section{References}

Anokye N.K., Lord J., Fox-Rushby J. (2014): Is brief advice in primary care a cost-effective way to promote physical activity? Br. J. Sports Med. 48 (3): 202-206.

Bauman A., Reis R., Sallis J.F., Wells J., Loos R., Martin B.W., for the Lancet Physical Activity Series Working Group (2012): Physical Activity 2 - Why are some people physically active and others not? Understanding the correlates of physical activity. Lancet 380 (9838): 294-305.

Bellew B., Bauman A., Martin B.W., Bull B., Matsudo V. (2011): Public Policy Actions Needed to Promote Physical Activity. Current Cardiovascular Risk Reports doi: 10.1007/s12170-011-0180-6.

BFS (2013): Schweizerische Gesundheitsbefragung 2012 Übersicht (Leporello). Bundesamt für Statistik BFS, Neuchâtel.

Bize R., Surbeck R., Padlina O., Peduzzi F., Cornuz J., Martin B. (2008): Promotion of physical activity in the primary care setting: The situation in Switzerland. Schweiz. Z. Sportmed. Sporttraumatol. 56 (3): 112-116.

Campbell F., Blank L., Messina J., Day M., Buckley Woods H., Payne N., Goyder E., Armitage C. (2012): Physical activity: Brief advice for adults in primary care (National Institute for Health and Clinical Excellence Public Health Intervention Guidance). NICE, London.

Currie C., Zanotti C., Morgan A., Currie D., de Looze M., Roberst C., Samda O., Smith O.R.F., Barnekow V. (eds.) (2012) : Social determinants of health and well-being among young people. Health Behaviour in School-aged Children (HBSC) study: international report from the 2009/2010 survey. WHO Regional Office for Europe, Copenhagen (Health Policy for Children and Adolescents, No. 6)

FOSPO, Federal Office of Public Health FOPH, Health Promotion Switzerland, bfu - Swiss Council for Accident Prevention, Swiss Accident Insurance Fund (Suva), Health and Physical Activity Network Switzerland (2013): Health-Enhancing Physical Activity. Core document for Switzerland. Federal Office of Sport FOSPO, Magglingen.

GAPA (2010): The Toronto Charter for Physical Activity: A Global Call to Action. Global Advocacy Council for Physical Activity GAPA, Internationa Society for Physical Activity and Health ISPAH (www.globalpa.org.uk).

GAPA (2011): Non communicable disease prevention: Investments that work for physical activity. Global Advocacy Council for Physical Activity GAPA, International Society for Physical Activity and Health ISPAH (www.globalpa. org.uk).

Garrett S., Elley C.R., Rose S.B., O〉Dea D., Lawton B.A., Dowell A.C. (2011) Are physical activity interventions in primary care and the community costeffective? A systematic review of the evidence. Br. J. Gen. Pract. 61 (584): e125-133.

Heath G.W., Parra D.C., Sarmiento O.L., Andersen L.B., Owen N., Goenka S., Montes F., Brownson R.C. (2012): Evidence-based intervention in physical activity: lessons from around the world. Lancet 380 (9838): 272-281.

Kahlmeier S., Alpiger P., Martin B. (2012): National recommendations for health-enhancing physical activity: the situation for Switzerland in 2011 and options for further developments. Schweiz Z Sportmed Sporttraumat 60 (3): 96-101.

Koutaissoff D., Jeannin A., Dubois-Arber F. (2012) : Evaluation de la formation PAPRICA (Physical Activity promotion in PRImary CAre). Institut universitaire de médecine sociale et préventive, Lausanne (Raisons de santé, 200).

Lee I.-M., Shiroma E.J., Lobelo F., Puska P., Blair S.N., Katzmarzyk P.T., for the Lancet Physical Activity Series Working Group (2012): Effect of physical inactivity on major non-communicable diseases worldwide: an analysis of burden of disease and life expectancy. Lancet 380 (9838): 219-29.

Lin J.S., O>Connor E., Whitlock E.P., Beil T.L. (2010): Behavioral counseling to promote physical activity and a healthful diet to prevent cardiovascular disease in adults: a systematic review for the U.S. Preventive Services Task Force. Ann. Intern. Med. 2010153 (11): 736-50.

Martin B., Padlina O., Martin E., Bize R., Cornuz J., Kahlmeier S. (2013): Bewegungsförderung 2013/Promotion de l'activité physique 2013. Physioactive (5): 21-27.

Martin B.W. (2014): Health-enhancing physical activity in Europe and in Switzerland: the health care setting and beyond. Schweiz. Z. Sportmed. Sporttraumatol. 62 (2): 5-6.

Martin B.W., Mäder U., Stamm H.P., Braun-Fahrländer C. (2009): Physica activity and health - what are the recommendations and where do we find the Swiss population? Schweiz Z Sportmed Sporttraumatol 57 (2): 37-43.

Martin-Diener E, Martin BW (2009): Two base documents for Switzerland: "Health-Enhancing Physical Activity" and "Muscle-Powered Mobility". Schweiz Z Sportmed Sporttraumatol 57 (2): 44-47.

Martin-Diener E,. Kahlmeier S., Vuillemin A., van Mechelen W., Vasankari T., Racioppi F., Martin B. W. (2014): 10 years of HEPA Europe: what made it possible and what is the way into the future? Schweiz. Z. Sportmed. Sporttraumatol. 62 (2): 6-12.

Neuner-Jehle S., Schmid M., Grüninger U. (2013): The «Health Coaching» programme: a new patient-centred and visually supported approach for health behaviour change in primary care. BMC Fam. Pract. 4: 100

Orrow G., Kinmonth A.L., Sanderson S., Sutton S. (2012): Effectiveness of physical activity promotion based in primary care: systematic review and meta-analysis of randomised controlled trials. Brit Med. J. 344: e1389. doi: 10.1136/bmj.e1389.

Padlina O., Jimmy G., Martin B.W. (2009): Acceptance of an Internet-based programme to train physical activity counsellors during the development phase and in regular use. Schweiz. Z. Sportmed. Sporttraumatol. 57 (2): 65-68. Schmid M., Egli K., Martin B.W., Bauer G. (2009): Health promotion in primary care: evaluation of a systematic procedure and stage specific information for physical activity counselling. Swiss Med. Wkly 139 (45-46): 665-671.

Tulloch H., Fortier M., Hogg W. (2006): Physical activity counseling in primary care: who has and who should be counseling? Patient Educ. Couns. 64 (1-3): 6-20. 


\title{
The Evolution of Physical Activity on Prescription $(\mathrm{FaR})$ in Sweden
}

\author{
Anders Raustorp ${ }^{1,2}$, Carl Johan Sundberg ${ }^{3}$ \\ ${ }^{1}$ Department of Nutrition and Sport Science, University of Gothenburg, Sweden \\ 2 Department of Sport Science, Linnaeus University Kalmar, Sweden \\ ${ }^{3}$ Department of Physiology and Pharmacology, Karolinska Institutet, Stockholm, Sweden
}

\begin{abstract}
In 1996, the first Report of the US Surgeon General on Physical Activity and Health provided an extensive knowledge overview about the positive effects of physical activity (PA) on several health outcomes and PA recommendations. This contributed to an enhanced interest for PA in Sweden. The Swedish Professional Associations for Physical Activity (YFA) were appointed to form a Scientific Expert Group in the project "Sweden on the Move" and YFA created the idea of Physical Activity on Prescription (FaR) and the production of a handbook (FYSS) for healthcare professionals. In Swedish primary care, licensed healthcare professionals, i.e. physicians, physiotherapists and nurses, can prescribe PA if they have sufficient knowledge about the patient's current state of health, how PA can be used for promotion, prevention and treatment and are trained in patient-centred counselling and the FaR method. The prescription is followed individually or by visiting local FaR providers. These include sport associations, patient organisations, municipal facilities, commercial providers such as gyms, sports clubs and walking clubs or other organisations with FaR educated staff such as health promoters or personal trainers. In clinical practice, the FaR method increases the level of PA in primary care patients, at 6 and at 12 months. Self-reported adherence to the prescription was $65 \%$ at 6 months, similar to the known compliance for medications. In a randomised controlled trial, FaR significantly improved body composition and reduced metabolic risk factors. It is suggested that a successful implementation of PA in healthcare depends on a combination of a systems approach (socio-ecological model) and the strengthening of individual motivation and capability. General support from policymakers, healthcare leadership and professional associations is important. To lower barriers, tools for implementation and structures for delivery must be readily available. Examples include handbooks such as FYSS, the FaR system and the use of pedometers.
\end{abstract}

Keywords:Physical activity, healthcare, counselling, chronic disease, prevention, Sweden

\section{Zusammenfassung}

1996 wurden im «Report of the US Surgeon General on Physical Activity and Health» das Wissen zu den Effekten von Bewegung auf die Gesundheit und die Bewegungsempfehlungen erstmals umfassend dargestellt. Dies führte in Schweden zu einem gesteigerten Interesse am Thema Bewegung. Die schwedischen Fachverbände im Bewegungsbereich wurden eingeladen, im Rahmen des Projektes «Sweden on the Move» eine wissenschaftliche Expertengruppe zu bilden. Die Gruppe entwickelte das Konzept von «Bewegung auf Verschreibung» (FaR) und verfasste dazu ein Handbuch (FYSS) für Fachleute im Gesundheitswesen. In der schwedischen Grundversorgung können Ärzte, Physiotherapeuten und Pflegefachkräfte Bewegung verschreiben, falls sie den Gesundheitszustand des Patienten beurteilen könne, geschult in der Anwendung von körperlicher Aktivität in Prävention und Therapie sowie ausgebildet in patientenzentrierter Beratung und der FaR-Methode sind. Die Verschreibung kann individuell oder im Rahmen eines lokalen FaR-Angebots organisiert durch Sportverbände, Patientenorganisationen, Gemeindeinstitutionen, private Anbieter oder andere Vereinigungen mit ausgebildetem FaR-Personal (Gesundheitsförderer, Personal Trainers) umgesetzt werden. Im klinischen Alltag wird beobachtet, dass FaR das Bewegungsverhalten der Patienten nach 6 und 12 Monaten verbessert. Die selbstberichtete Compliance mit der Verschreibung nach 6 Monaten war $65 \%$, also vergleichbar mit Medikamenteneinnahme. In einer randomisierten kontrollierten Studie zeigte die FaR-Methode eine signifikante Verbesserung der Körperzusammensetzung und der metabolischen Risikofaktoren. Die erfolgreiche Umsetzung der Bewegungsförderung in der Primärversorgung basiert auf der Kombination eines systemischen Ansatzes (sozio-ökologisches Modell) mit der Stärkung individueller Motivation und Fähigkeiten. Die Unterstützung durch Politik und das Gesundheitswesen sind wichtig. Zum Abbau von Barrieren braucht es Instrumente und Strukturen für die Umsetzung wie Handbücher, das FaR-System oder den Einsatz von Pedometern.

Schlüsselwörter: Physical activity, healthcare, counselling, chronic disease, prevention, Sweden 
The Evolution of Physical Activity on Prescription $(\mathrm{FaR})$ in Sweden

Health care plays an essential role for the promotion of physical activity, fitness and health. Physicians, physiotherapists and nurses can and should all contribute. It is necessary that prevention and treatment methods are evidence-based. Therefore, education and training activities for healthcare professionals on all aspects of physical activity on prescription are needed. Also, knowledge tools and resources are important elements.

In the mid 1990s, an accumulating body of evidence about the positive effects of physical activity on several health outcomes and the novel physical activity recommendations presented in a report of the US Surgeon General (USDHHS 1996) contributed to an enhanced interest in Sweden. The Swedish National Institute of Public Health appointed the Swedish Professional Associations for Physical Activity (YFA) to form a Scientific Expert Group in the task to put "Sweden on the Move". In this large scale health promotion operation, different arenas in society, such as school, leisure time, workplace and healthcare were included. Within the healthcare setting, YFA formed the idea of Physical Activity on Prescription (FaR).

Before launching FaR, a survey called the Waiting Room Study revealed that 9 out of 10 patients in a primary care waiting room preferred physical activity over drug treatment if the outcome was the same (Leijon et Kallings, 2003).

In Swedish primary care, licensed health professionals such as physicians, physiotherapists and nurses can prescribe physical activity (FaR). The licensed professionals must have sufficient knowledge about the patient's current state of health, how physical activity can be used for promotion, prevention and treatment, knowledge of patient-centred counselling, the FaR method and the local FaR providers.

The prescription can be follow individually or by visiting local FaR providers, e.g. gyms, sports clubs, walking clubs or other associations with FaR educated staff such as health promoters, personal trainers or club members. The FaR education was created based on a pilot education program during 2001. This program revealed the need for different approaches depending on living conditions of patients and their access to clubs and gyms. In this program, the use of pedometers was introduced in Swedish Health Care as a tool for intervention and evaluation and for those who prefer to follow the prescription on their own. It also identified ethical questions on how to communicate information about a patient's health status outside the healthcare system as well as a lack of compatibility with existing patient record systems (Leijon et Kallings, 2003). Furthermore, the need was identified for a handbook based on the evidence about physical activity in the prevention and treatment of disease. Therefore, YFA took the responsibility to write the first edition of the 600-page book FYSS in 2003 which is now available in a second edition also in English (SNIPH 2010). It contains the scientific background on current PA recommendations for almost 40 diseases (e.g. cardiovascular, metabolic, orthopaedic, psychiatric, pulmonary, and neurologic diseases or cancer) or conditions (e.g. pregnancy, old age).

\section{Establishment of the approach}

The Swedish Council on Technology Assessment in Health Care (SBU) report concluded that general 'brief' advice on physical activity could increase the level of physical activity by up to $50 \%$ at 6 months (SBU 2007). With more intense counselling, supported by pedometers, written advice and/or follow-ups, the level of physical activity may increase a further $15-50 \%$ at 6 months.

The pilot work, the SBU report and the further development in different county councils and regions has contributed to form today's FaR. The core aspect of FaR is its patient-centred dialogue approach with its origin in the patient's state of health, symptoms, diagnoses, potential risk factors, prior experience of physical activity and preferred activities. The counselling leads to a written prescription and the basis of the prescription is the handbook FYSS.

The prescribed activity can either be performed individually or with local activity organizers. The cooperation between the Health Care System and various physical activity organizers in the local community (NGOs such as sport associations, patient organizations or municipal facilities and private business) helps increase or maintain the level of physical activity. The concept of individualized counselling and prescription in combination with the cooperation between the Health Care System and NGOs seem to be unique (Kallings, 2011).

Many patients prefer to be physically active on their own. Walking is reported to be the most preferred physical activity (Ham et al., 2009). Following the SBU report (SBU 2007), a common approach among Swedish physiotherapists is to use pedometers to help increase physical activity levels (Raustorp 2013). An important part is the follow-up, i.e. the monitoring of progress and the possible adjustment of the prescription. With a validated pedometer it is possible to bridge the gap between research and practice. The most recent physical activity recommendations are expressed as steps per day (Garber et al., 2011). In a review, the Lancet (Heath et al., 2012) reported that interventions using pedometers had the largest effect size among evidence based interventions to increase physical activity.

\section{Results so far}

In clinical practice, the Swedish $(\mathrm{FaR})$ method has been found to increase the level of physical activity in patients in primary care, at 6 months as well as at 12 months (Leijon et al, 2009). The self-reported adherence to the prescription was $65 \%$ at 6 months (Kallings et al, 2009a), a fraction well in correspondence with the known compliance rate of medications. In a randomized controlled study, physical activity on prescription significantly improved body composition and reduced metabolic risk factors (Kallings et al,. 2009b).

Today FaR is implemented in all Swedish councils and it is widely spread in primary care. It is also increasingly used in specialist care, especially in psychiatry (Kallings 2011).

However, physical activity as a treatment modality in healthcare is still underutilized. While physicians believe that advice on PA is important, only a small minority of patients is actually given advice or counselling on PA in the clinical setting. There are no comprehensive statistics about prescriptions on a national basis. A rough estimate is that 50'000 prescriptions were given in 2010 with an increasing trend and at present about $1 / 1000$ of the Swedish healthcare visits result in a prescription of physical activity (Kallings 2012).

The Swedish National Board of Health and Welfare recently produced national guidelines on methods to prevent disease (Socialstyrelsen 2011) highlighting the importance of structured advice, with additional support and follow-up (equivalent to physical activity on prescription), to increase the PA level in 
insufficiently active patients at risk for diseases such as obesity, diabetes and hypertension.

One of the main challenges may be that some physicians do not regard lifestyle issues to be their responsibility. Possibly this is because they do not fully realise the massive potential treatment effects of PA for many of their patients with non-communicable diseases, that is for most patients in everyday practice.

\section{Lessons learned and the way forward}

It has been suggested that a successful implementation of physical activity counselling in healthcare depends on a combination of a systems approach (socio-ecological model) and the strengthening of individual motivation and capability (Börjesson et Sundberg, 2013). First, there needs to be general support from the policymakers, healthcare leaders and from professional societies. This should be expressed through national evidence-based recommendations and guidelines as well as through educational programmes, all the way from undergraduate levels up to continuing medical education. Such measures increase awareness and legitimacy and help to enhance motivation. Second, to lower the barrier for the prescribing healthcare professionals, tools for implementation and structures for delivery must be readily available (Börjesson et Sundberg, 2013). Examples include handbooks such as FYSS and physical activity on prescription systems and methods such as the use of pedometers as supported by the evidence.

The FYSS book has been translated into English, Norwegian and Vietnamese (Hellenius et Sundberg, 2011) and discussions are ongoing for other languages. The Vietnamese translation was part of a collaboration project that included education and training of healthcare personnel, awareness building through mass media campaigns as well as interaction with the Vietnamese government. Swedish Professional Associations for Physical Activity actively seek collaborators around the world to make further translations.

\section{Corresponding author:}

Anders Raustorp, Associate Professor, University of Gothenburg/Linnaeus University, Sweden.

Telephone +46708 118 706, E-Mail: anders.raustorp@ped.gu.se

\section{References}

Börjesson M., Sundberg C.J. (2013): FYSS (physical activity book for prevention and treatment): behavioural change also for the physician? Br. J. Sports Med. 47 (15): 937-8.

Garber C.E., Blissmer B., Deschenes M.R., Franklin B.A., Lamonte M.J., Lee I.M., Nieman D.C., Swain D.P. (2011): Quantity and quality of exercise for developing and maintaining cardiorespiratory, musculoskeletal, and neuromotor fitness in apparently healthy adults: guidance for prescribing exercise. Med. Sci. Sports. Exerc. 43 (7): 1334-1359.

Ham S.A., Kruger J., Tudor-Locke C. (2009): Participation by US adults in sports, exercise, and recreational physical activities. J. Phys. Act. Health. 6: $1-10$.

Heath G.W., Parra D.C., Samiento O.L., Andersen L.B., Owen N., Goenka S., Montes F., Brownson R.C., for the Lancet Physical Activity Series Working Group (2012): Evidence-based interventions in physical activity: lessons from around the world. Lancet 380 (9838): 272-281.

Hellénius M.L., Sundberg C.J. (2011): Physical activity as medicine - time to translate evidence into clinical practice (editorial). Br. J. Sports Med. 45 (3): 158 .

Kallings L.V. (2011): Individually adapted written prescription of physical activity-FaR. National Institute of Public Health, Östersund.

Kallings L.V. (2012): Fysisk aktivitet på recept - en underutnyttjad resurs. Stora variationer mellan landstingen, visar statistik över förskrivningen [Physical activity on prescription - a underutilized method! Statistics on prescription shows large variations among counties]. Lakartidningen 109 (51-52): 2348-50.

Kallings L.V., Leijon M.E., Kowalski J., Hellenius M.L., Ståhle A. (2009a): Self-reported adherence: a method for evaluating prescribed physical activity in primary health care patients. J. Phys. Act. Health 6: 483-492.

Kallings L.V., Sierra-Johnson J., Fischer R.M., de Faire U., Ståhle A., Hemmingsson E. Hellénius M.L. (2009b): Beneficial effects of individualized physical activity on prescription on body composition and cardiometabolic risk factors: results from a randomized controlled trial. Eur. J. Cardiovasc. Prev. Rehabil. 16 (1): 80-4.

Leijon M., Kallings L.V. (2003): Erfarenheter av fysisk aktivitet på recept. [Experiences with physical activity on prescription]. Folkhälsoinstitutet, Stockholm.

Leijon M.E., Bendtsen P., Nilsen P., Festin K., Ståhle A. (2009): Does a physical activity referral scheme improve the physical activity among routine primary health care patients? Scand. J. Med. Sci. Sports. 19 (5): 627-36. Raustorp A. (2013): Fysisk aktivitet och fysisk självkänsla. [Physical activity and physical self esteem]. Kunskapsforetaget AB, Uppsala.

SBU (2007): Metoder för att främja fysisk aktivitet. En systematisk litteraturöversikt [Methods of promoting physical activity. A systematic literature survey]. Summary in English. Swedish Council on Technology Assessment in Health Care, Stockholm.

SNIPH (2010): Physical activity in the prevention and treatment of disease. Professional Associations for physical activity. Swedish National Institute of Public Health SNIPH; Stockholm. www.fyss.se, accessed at 23.05.2014 Socialstyrelsen (2011): National guidelines for methods of preventing disease. Swedish National Board of Health and Welfare (Socialstyrelsen), Stockholm. www.socialstyrelsen.se, accessed at 23.05.2014

USDHHS (1996): Physical Activity and Health: A Report from the Surgeon General, U.S. Department of Health and Human Services USDHHS, Centers for Disease Control and Prevention, National Center for Chronic Disease Prevention and Health Promotion, Atlanta. 


\title{
Experiences in physical activity promotion in health care settings for primary prevention in the UK
}

\author{
Malcolm Ward \\ Public Health Wales, Cardiff, Wales
}

\begin{abstract}
In addition to the delivery of primary care services, recent changes to the NHS in the United Kingdom have placed increasing responsibility on GPs for the commissioning of the full range of health services from prevention through to clinical interventions and rehabilitation. Whilst historically there has always been an expectation that primary care professionals were ideally placed to provide support for prevention as well as treatment, their active engagement in the promotion of physical activity has remained largely superficial. With notable exceptions where individuals have a personal interest or commitment, the majority of health professionals tend to limit themselves to peremptory nonspecific advice at best, or frequently don't broach the subject at all. There are a number of reasons for this including increasing time pressures, a general lack of knowledge, limited evidence and concerns about litigation in the event of an adverse exercise induced event. However in the 1990s there was a surge of interest in the emerging "Exercise on Prescription" model where patients could be referred to community based exercise instructors for a structured "prescription" of exercise in community leisure centres. Despite the continuing popularity of the model there remain problems particularly in getting the active support of health professionals who generally cite the same barriers as previously identified. In an attempt to overcome some of these problems Wales established a national exercise referral scheme with an associated randomised controlled trial. The scheme evaluated well and had subsequently evolved with new developments including integration with secondary and tertiary care pathways, accredited training for exercise instructors and exit routes into alternative community based exercise opportunities.
\end{abstract}

Keywords: physical activity, healthcare, counselling, chronic disease, prevention, Wales, United Kingdom

\section{Zusammenfassung}

Kürzliche Änderungen beim nationalen Gesundheitssystem NHS in Grossbritannien haben dazu geführt, dass medizinische Grundversorger zunehmend Verantwortung auch für Prävention, klinische Interventionen und Rehabilitation übertragen bekommen haben. Traditionellerweise ist davon ausgegangen worden, dass die Hausarztpraxis das ideale Setting nicht nur für die Behandlung, sondern auch für die Verhütung von Krankheiten darstellt. Tatsächlich hat aber - bei löblichen Ausnahmen in Einzelfällen - nur ein begrenztes Engagement in diesem Bereich stattgefunden, Prävention findet oft nur in Form von allgemeinen direktiven Ratschlägen statt, oder das Thema wird gar nicht angesprochen. Gründe dafür sind unter anderem der zunehmende Zeitdruck, begrenztes Wissen, begrenzte wissenschaftliche Evidenz und auch die Angst vor haftungsrechtlichen Ansprüchen bei Zwischenfällen im Zusammenhang mit mehr Bewegung. In den 1990erJahren stieg aber das Interesse am Modell der «Bewegung auf Rezept» stark an, bei der Patientinnen und Patienten für ein strukturiertes Trainingsprogramm an Bewegungsinstruktoren in gemeindebasierten Freizeitzentren überwiesen werden konnten. Obwohl dieser Ansatz nach wie vor sehr beliebt ist, gibt es immer noch Probleme bei der Umsetzung, besonders was die aktive Unterstützung durch die medizinischen Grundversorger angeht. Diese berichten im Wesentlichen immer noch über die gleichen Barrieren wie früher. Als Antwort darauf hat Wales ein nationales «Exercise Referral Scheme» (Trainingsüberweisungsmodell) etabliert und mit einer kontrolliert randomisierten Studie auch erfolgreich evaluiert. Aktuelle Entwicklungen umfassen hier die Integration auch mit der Sekundär- und Tertiärversorgung, standardisierte Ausbildungsgänge für Bewegungsinstruktoren und die Vernetzung mit anderen Bewegungsmöglichkeiten in der Gemeinde.

Schlüsselwörter: Physical activity, healthcare, counselling, chronic disease, prevention, Wales, United Kingdom 


\section{Introduction}

Approaches and models of physical activity promotion in the healthcare sector over the last twenty five years have varied considerably within and across countries influenced by both the healthcare systems and the roles of professionals within those systems. However, irrespective of the system the primary care physicians and their teams have consistently been a pivotal influence. A range of interventions have been delivered through this system ranging from "brief interventions" by General Practitioners GPs through to more directed interventions such as "exercise prescription" schemes that direct specific patients to formal exercise programmes, usually in the community.

However experience suggests resistance, in GPs and other physicians to engage in actively promoting physical activity amongst their patients (Ward et al., 2010). Historically they have cited a lack of evidence, time and trust in exercise professionals for their antipathy. And whilst there is some merit in these concerns, there is increasing evidence of a simple lack of knowledge regarding physical activity and health amongst health professionals (Weiler et al., 2013, West 2013, Philips 2012) that undoubtedly undermines their confidence and ability to fulfil a role that they perceive as having potentially harmful clinical and legal consequences.

\section{Exercise Referral Schemes}

The early 1990s saw the emergence of a new approach to promoting physical activity through primary care in the UK with the advent of "exercise on prescription" or "exercise referral" schemes. The premise was very simple; patients at risk of chronic disease would be assessed by their GP and where appropriate directed to a structured exercise programme usually delivered in a local authority leisure centre by exercise instructors. Early results appeared very promising with everyone seeming to benefit (Taylor et al., 1998), the GP would be better able to manage patients, leisure providers would be able to attract a whole new customer base and the patients themselves would get huge health benefits, and in no time at all schemes were proliferating all over the country. By 1998 there were estimated to be over 200 schemes operating across the UK (Riddoch et al., 1998).

However, this early promise wasn't reflected in the evidence and a number of reviews suggested serious limitations (Riddoch et al, 1998, Gidlow et al., 2005). These were due in part to the poor evaluations associated with the schemes that led to questionable results and unsubstantiated claims. Nonetheless, the model remained very popular and numbers of schemes continued to rise. Some of the concerns expressed by GP's and others were addressed including the establishment of national guidelines (NHS 2001) and statements of support by the medical defence unions (BHF National Centre for Physical Activity and Health 2010). But concerns remained as doubts were raised about;

- the limitations of short term programmes;

- the lack of follow-up data;

- the apparent low adherence rates by patients on the schemes;

- the lack of robust evidence on health outcomes;

- the lack of cost effectiveness data;

- the continuing reluctance of GPs to refer patients;

This culminated in an evidence review by the National Institute for Health \& Clinical Excellence (NICE) which con- cluded there was "insufficient evidence to recommend the use of exercise referral schemes to promote physical activity, other than as part of research studies where their effectiveness can be evaluated." (NICE 2006).

\section{Wales National Exercise Referral Scheme}

During the development of the NICE review the Welsh Assembly Government was establishing a National Exercise Referral Scheme (NERS), the first national scheme of its type in the world. At that time there was a wide range of different local schemes in operation across Wales, so the Welsh Government decided to trial a single model that would be developed along national guidelines, operate across the whole country and be evaluated using a randomised controlled trial. The intervention included a 32 session supervised exercise programme at a local leisure centre with follow-up at 6 and 12 months. The scheme was launched in 2007 and for the purposes of the research only took patients with either primary coronary hear disease or a mild to moderate depression referral. The trial was completed and the results published in 2010 (Murphy et al., 2010).

2160 participants took part in the trial with $44 \%$ adherence at 16 weeks. There were significant improvements in both physical and mental health and significant increases in physical activity amongst those referred with a CHD risk diagnosis, though not amongst those referred with a depression or anxiety diagnosis. A cost-effectiveness analysis indicated a cost per QALY of $£ 12,111$, well inside the NICE threshold of $£ 20,000$ to $£ 30,000$ (www.nice.org.uk). In short the trial had shown the scheme to be both effective and cost-effective.

Since the end of the trial the scheme has continued to expand and develop with over 25,000 patients a year now accessing it and the 16 week adherence rate over $55 \%$. It has extended the range of referrals to incorporate most sedentary patients with chronic conditions. A national database has been established and the range of data increased to include a variety of physiological, demographic, health outcome and exercise data as well as monitoring attendances, activities, etc. New technologies are being trialled including the use of cloud-based personal monitoring devices that use accelerometry to monitor activity throughout the day. Referral points have been extended to include community services such as pharmacies and secondary care and rehabilitation services. The scheme is being incorporated into chronic disease care pathways and trials with overweight patients awaiting hip and knee surgery have indicated not only significant improvements in their general health and their mobility but even suggest some patients can be removed from the surgical waiting lists. These small scale preliminary studies have naturally generated research interest and more substantive studies are being planned. Finally broadening the range of activity options is being explored, with exit routes into community walking programmes, and "green" exercise amongst those being offered and Tai Chi, dance and other community activities being considered for further development.

A recent review of national health improvement programmes (Public Health Wales 2013) identified the scheme as one of those worthy of continuing support and new developments are being considered including the establishment of a second tier of referrals who do not require the close supervision indicated by the clinical criteria but who would benefit from professional support, advice and signposting. 


\section{Key Developments}

The concerns about exercise referral schemes expressed in early reviews and highlighted by the NICE guidance were well founded but have now largely been addressed and the evidence from Wales suggests that there is an effective and potentially promising model to be developed further. However, it remains the case that there are still a majority of GPs and other physicians who are not using these schemes. The development of the PAR-Q-Plus risk assessment tool at the University of British Columbia (www.eparmedx.com) may help address some of these problems by providing a simple evidence-based algorithm that can direct patients with any given condition to the appropriate exercise options. This benefits GPs who can now quickly assess the exercise needs of their patients and signpost them to the appropriate intervention, but could in theory be used by patients themselves to identify their own options. The tool is presently undergoing validation and ethical approval for use in the UK.

The second key development that marks the UK system out as unique is the establishment of a comprehensive range of nationally accredited training packages that exercise professionals need to work with patients including a generic qualification for exercise referral and a range of higher qualifications covering cardiac rehabilitation, back care, falls prevention, stroke, diabetes, weight management, mental health, cancer and chronic obstructive pulmonary disease (www.exerciseregister.org). Over 200 exercise professionals have been trained in Wales and many more across the UK and their enhanced skills and knowledge are not limited to dealing with exercise referral patients but are equally valid when managing their routine clientele attending local facilities.

\section{Health Professional Education}

A continuing concern that informs discussions around the promotion of physical activity for health is the evident gap between public expectations of health professionals and their knowledge. Several studies and papers (Joy et al., 2013, Dunlop et Murray, 2013)), including a recent survey by the Health Enhancing Physical Activity (HEPA) network Europe, have now identified this as a global issue that starts with a lack of education at entry level for doctors and that persists through medical specialities and into General Practice. To help address this there have been a number of online professional development tools developed including one called "Motivate2Move" developed by a GP in North Wales and hosted by the Deanery at Cardiff University (www.gpcpd. walesdeanery.org). A similar resource called "Every step counts" has been launched by NHS Scotland(www.elearning. healthscotland.com) to accompany their Physical Activity Care Pathway and a more generic tool is being developed through an EU funded project addressing CHD risk factors (Leonardo UK 2011).
Despite these advances there is an increasing recognition that medical curriculums need to be better informed with a stronger emphasis on the role and impact of physical activity not only as an effective therapeutic intervention for many medical conditions but also as an important preventative tool for many more chronic conditions.

\section{Corresponding author:}

Malcolm Ward FFPH, MPH, PG Dip, Principal Health

Promotion Specialist, Public Health Wales, Hadyn Ellis

Building, Maindy Road, Cathays, Cardiff, Wales, CF24 4HQ

Phone 02921 841944, E-Mail: malcolm.ward2@wales.nhs.uk

\section{References}

NHS (2001): Exercise referral systems: A national quality assurance framework. Department of Health, London.

Dunlop M., Murray A.D. (2013): Major limitations in knowledge of physical activity guidelines among UK medical students revealed: implications for the undergraduate medical curriculum. Br. J. Sports Med. 47 (11): 718-720. Edward M., Phillips E.M. (2012): A Call to Arms (and Legs): Exercise Prescription for Medical Students. PM. R. 4 (11): 914-918.

Gidlow C., Johnston L.H., Crone D.C, James D. (2005): Attendance of exercise referral schemes in the UK: A systematic review. Health Educ. J., 64 (2): 168-186.

Joy E.L., Blair S.N., McBride P., Sallis R. (2013): Physical activity counselling in sports medicine: a call to action. Br. J. Sports Med. 47 (1): 49-53.

Leonardo (2011): Transfer of Innovation: Directory of UK pProject call. Leonardo UK National Agency, Birmingham, p. 59.

Murphy S., Raisanen L., Moore G., Tudor-Edwards R., Linck P., Hounsome N., Williams N., Ud Din N., Moore L. (2010): The Evaluation of the National Exercise Referral Scheme in Wales. Welsh Assembly Government Social Research, Cardiff.

NICE (2006). Four commonly used methods to increase physical activity: brief interventions in primary care, exercise referral schemes, pedometers and community-based exercise programmes for walking and cycling. Public Health Intervention Guidance No. 2. National Institute for Health and Care Excellence, London and Manchester.

Public Health Wales (2013): Transforming Health Improvement in Wales: Working together to build a happier, healthier future. Public Health Wales NHS Trust, Cardiff.

Riddoch C., Puig-Ribera A., Cooper A. (1998): Effectiveness of physical activity promotion schemes in primary care: a review. Health Education Authority, London.

Taylor A.H., Doust J., \& Webborn N. (1998): Randomised controlled trial to examine the effects of a GP exercise referral programme in Hailsham, East Sussex, on modifiable coronary heart disease risk factors. J. Epidemiol. Comm. Health. 52 (9): 595-601.

The British Heart Foundation National Centre for Physical Activity and Health (2010): A Toolkit for the design, implementation and evaluation of exercise referral schemes. Loughborough University, Loughborough, p. $117 / 130$.

Ward M, Phillips CJ, Farr A, \& Harries D (2010): Heartlinks: A real world approach to Exercise Referral. Int. J. Health Prom. Educ. 48 (1): 20-27. Weiler R, Chew S, Coombes N, Hamer M, Stamatakis (2012): Physical activity education in the undergraduate curricula of all UK medical schools: are tomorrow $>$ s doctors equipped to follow clinical guidelines? Br. J. Sports Med. 46 (14): 1024-1026.

West L.R. (2013): Sport and exercise medicine in the undergraduate curriculum. Are we inspiring the next generation of sport and exercise medicine doctors and helping them overcome the barriers they face getting into the specialty? Br. J. Sports Med. 47 (11): 664-665. 


\title{
Exercise Referral in Germany
}

\author{
Eszter Füzéki, Winfried Banzer \\ Department of Sports Medicine, Goethe University, Frankfurt
}

\section{Summary}

Primary care physicians in Germany are potentially in a pivotal position to provide physical activity counselling and exercise referral for their patients. The preventative prescription scheme dates back to the late 1970s. This scheme called "green prescription" (Grünes Rezept), however, could not be established as exercise referral scheme in primary care on a regular and systematic basis. After the German Medical Association (Bundesärztekammer), the German Association for Sports Medicine and Prevention (Deutsche Gesellschaft für Sportmedizin und Prävention) and the German Olympic Sports Federation (Deutscher Olympischer Sportbund) had developed the standardized national quality criteria of Physical Activity on Prescription in a joint effort, the German Medical Association has adopted them in 2011 and now recommends them to the Medical Associations of the Federal States for implementation. These national criteria establish a framework, but given the federal structure of Germany, schemes are not implemented in a uniform or centralized way. The federal states rather develop their own delivery methods according to local possibilities and needs. Exercise as a therapeutic means in the rehabilitation phase of a large number of chronic conditions as well as for people with disabilities is a legally established part of health care. The current legal and financial bases as well as the level of institutionalised support for the prescription of physical activity and exercise within health care are markedly different in the areas of prevention and therapy, respectively. While patients with chronic conditions are entitled to receive free exercise as a means of therapy (within certain limitations), no such "right" exists in the area of prevention. Exercise referrals rely on group offers with defined high standards in organised sports, making use of easily accessible sport clubs which are a traditional part of community life. Rigorous scientific evaluations are needed to provide guidance on how to further develop Germany's exercise referral schemes.

Keywords: Physical activity, healthcare, counselling, chronic disease, prevention, Germany

\section{Zusammenfassung}

Niedergelassene Ärzte in Deutschland sind potenziell in einer Schlüsselposition, um Patienten zu körperlicher Aktivität und Bewegung zu beraten und ihnen diese zu verschreiben. Das erste präventiv orientierte «Rezept für Bewegung» (Grünes Rezept) wurde bereits in den späten 1970er Jahren initiiert. Das Grüne Rezept konnte jedoch die Verschreibung von Bewegung in der Primärversorgung nicht systematisch verankern. Nachdem die Bundesärztekammer, die Deutsche Gesellschaft für Sportmedizin und Prävention und der Deutsche Olympische Sportbund gemeinsam standardisierte nationale Qualitätskriterien für das «Rezept für Bewegung» entwickelt hatten, wurden diese 2011 von der Bundesärztekammer verabschiedet und den Landesärztekammern zur Umsetzung empfohlen. Die nationalen Kriterien schaffen einen Rahmen, angesichts der föderalen Struktur Deutschlands wird aber das «Rezept» nicht zentralisiert oder einheitlich eingesetzt. Jedes Bundesland adaptiert es nach seinen jeweiligen Möglichkeiten und Bedürfnissen. Sport als therapeutisches Mittel ist in der Rehabilitationsphase vieler chronischer Erkrankungen sowie für Menschen mit Behinderungen ein gesetzlich festgeschriebener Bestandteil der Gesundheitsversorgung. Aktuell zeigt sich ein deutlicher Unterschied bei der rechtlichen Grundlage, der Finanzierung, sowie der institutionalisierten Unterstützung für die Verschreibung von körperlicher Aktivität und Bewegung zwischen Prävention und Therapie. Während Patienten mit chronischen Erkrankungen mit einigen Einschränkungen berechtigt sind, kostenfreie Bewegungstherapie in Anspruch zu nehmen, besteht ein ähnliches Anrecht auf dem Gebiet der Prävention nicht. Durch die Einbindung der flächendeckenden und traditionell verankerten Sportvereine bilden die qualitativ gesicherten Gruppenangebote des organisierten Sports eine Basis sowohl für den präventiven als auch für den therapeutischen Ansatz. Rigorose wissenschaftliche Untersuchungen sind notwendig, um die Bewegungsberatung und -verschreibung in der ärztlichen Praxis in Deutschland weiterentwickeln zu können.

Schlüsselwörter: Physical activity, healthcare, counselling, chronic disease, prevention, Germany 


\section{Primary care in Germany}

Primary care practitioners play a major role in outpatient care in Germany. Primary care practitioner-focused care (hausarztzentrierte Versorgung) is described in paragraph 73 of the German Social Security Code Volume V. Primary care practitioners in Germany are, similarly to their counterparts in other Western countries, in a crucial gate-keeper's position in the health care system. They are seen as reliable sources of health information and typically maintain long-term relationships with patients. About $90 \%$ of the population see a primary care physician at least once a year (Streich 2002). Primary care is equally accessible for and utilized by socially vulnerable populations (Smythe et al. 2004). In the following paragraphs we will outline the role of outpatient physicians in exercise referral and physical activity counselling in Germany.

\section{Exercise as means of therapy and rehabilitation}

Exercise as a therapeutic means in the rehabilitation phase of a large number of chronic conditions as well as for people with disabilities is a legally established part of health care (Social Security Code Volume IX, Par. 44, Sec. 1.). All outpatient statutory health insurance physicians (Vertragsärzte) can prescribe 50 (in certain well-defined cases 120) sessions of group-based supervised exercise. As a general rule, patients are entitled to this prescription only once in a lifetime; the offer is seen as "help to self-help", with the ultimate goal of patients maintaining sufficient levels of activity by themselves, beyond the period covered by the prescription. Exercise groups are offered for specific diseases, and only group offers meeting the quality standards relating (among other criteria) to instructors' qualifications, group size, medical supervision during courses, emergency services and insurance as established in a framework agreement (BAR 2011) are eligible. Exercise offers within this scheme are free of charge for patients. Physicians receive no special reimbursement; exercise referral is covered as part of a per-patient lump-sum. Statutory health insurance funds (gesetzliche Krankenkassen) spent $€ 134$ million on exercise therapy and functional training in 2010, an increase of $31 \%$ since 2009.

\section{Physical activity and exercise in prevention}

The German Social Security Code Volume V, Par. 73, Sec. 1 requires that primary care services delivered by physicians include "the initiation or implementation of preventive and rehabilitative measures, as well as the integration of non-physician support and accompanying services into therapy", though without specifying the nature of these measures and services. In contrast to exercise as a means of therapy, physical activity counselling and exercise referral for prevention are factually voluntary, given this rather soft legal basis.

The German Exercise on Prescription Scheme in the area of prevention dates back to the late 1970s. The scheme called "green prescription" (Grünes Rezept), however, could not be established in primary care on a regular and systematic basis. After the German Medical Association (Bundesärztekammer), the German Association for Sports Medicine and Prevention (Deutsche Gesellschaft für Sportmedizin und Prävention) and the German Olympic Sports Federation (Deutscher Olympischer Sportbund) had developed the standardized national quality criteria of Physical Activity on Prescription in a joint effort, the German Medical Association adopted them in 2011 and now recommends them to the Medical Associations of the Federal States for implementation. Primary care physicians (niedergelassene Ärzte) are encouraged to refer their healthy but inactive patients (adults and children) to already existing group exercise offers with the quality seal "Sports Pro Health" ("Sport Pro Gesundheit") in local sports clubs. Certified "Sports Pro Health" offers must fulfil the following criteria: target group oriented courses, limited group size, qualified instructors, standardized structural organization, preventive health check up for participants and permanent quality control.

The national exercise referral criteria establish a framework, but given the federal structure of Germany, schemes are not implemented in a uniform or centralized way; the federal states rather adopt their own delivery methods according to local possibilities and needs. Currently 9 of the 16 federal states of Germany operate a scheme (Bavaria, Berlin, Bremen, Hamburg, Hesse, Rhineland-Palatinate, North Rhein-Westphalia, Schleswig-Holstein and Thuringia). Supporting materials such as posters, booklets, and flyers have been developed in all federal states using the logos of the three bodies behind the scheme and the "Sports Pro Health" logo to ensure brand recognition. Beyond this, federal states are free to use logos of their local partners, such as the sports federations and medical associations of their respective federal states.

The German exercise referral scheme in the area of prevention is entirely voluntary; physicians receive no compensation for their referral and patients are not entitled to reimbursement. Depending on the offers patients opt for, the costs might nonetheless be covered up to $80 \%$ by their health insurance funds, as defined by The Social Security Code (Volume V, Par. 20). In 2011 statutory health insurance funds (gesetzliche Krankenkassen) spent $€ 204$ million on courses for primary prevention, including exercise, diet, stress management and addiction prevention (MDS 2012). Around three quarters of all primary prevention courses were group exercise offers. Currently, health insurance funds cover a maximum of two courses per person per year. To be eligible for coverage, courses must have a defined duration, usually no more than 12 weeks. To date it has not yet been systematically assessed how many exercise referrals were initiated by physicians or the patients themselves, respectively. Beyond this coverage, no institutionalised funding or support is provided for the development and maintenance of the necessary structures, supporting materials and capacity building. In this regard, federal states and local communities must rely on their own resources and means.

\section{Exercise referral in the federal state of Hesse}

The exercise referral scheme "Rezept für Bewegung" in the German Federal State of Hesse is part of the network Sports and Health in Hesse, initiated in 2006 by the Sports Federation of the State of Hesse (Landessportbund Hessen). The overall goal of the network is to encourage all people in all age groups to become more active in general and not only in structured exercise programs. Members of the network are communities, local authorities, sports clubs, and primary care physicians. A major role of the network is to enhance the profile of sports and physical activity issues at the local and regional political level, and to create a link between politics, health care providers and sports clubs. The network also aims at improving the public 
visibility of physical activity and health related issues through organizing lectures and participating in community health fairs and other events. A side effect of the network have been the improved qualification of exercise instructors.

The network launches new projects, coordinates existing ones and aims at enhancing the impact of activities through synergies. Local regional networks are initiated by local regional sports umbrella organisations (Sportkreise). Communities provide political and financial support, know-how and sports facilities, and they function as door-openers for sports clubs.

Physicians interested in the project screen their patients for levels of physical activity and refer them to existing programs in the local sports clubs. The network provides support to participating physicians through the organisation of continuing professional development courses relevant for physical activity counselling. The network also compiles and regularly updates a directory of available programs of the sports clubs. This directory along with prescriptions and posters is made available to physicians. Also, a searchable internet database has been developed to facilitate referral. Currently further supporting materials, including a manual for physicians, are being developed by Goethe University Frankfurt, the German Medical Association, the German Association for Sports Medicine and Prevention and the German Olympic Sports Federation.

\section{Résumé and future directions}

Currently, the legal and financial bases as well as the level of institutionalised support for prescribing physical activity and exercise within health care are markedly different between the areas of prevention and therapy. While patients with chronic conditions are entitled to receive free exercise as a means of therapy (within the limitations described above) and the necessary infrastructure is part of the health care system, no such right or structures exist in the area of prevention. One common aspect is the referral to already existing offers of organised sport, in line with the strong German tradition and ubiquitousness of sports clubs. A major strength of this approach are the high standards of these offers guaranteed by quality assurance. Given the fact, however, that some patients might not wish to exercise in groups or might have limited access to such offers, not only exercise referral but also physical activity counselling should be encouraged within the health care system.

Until now, no rigorous scientific evaluation of physical activity counselling or exercise referral has been conducted in Germany. Such an evaluation seems to be essential before schemes can be further developed.

\section{Corresponding author:}

Eszter Füzéki, M.A. Gesundheitsförderung - und management, Johann Wolfgang Goethe-Universität Institut für Sportwissenschaften, Abteilung Sportmedizin Ginnheimer Landstrasse 39, 60487 Frankfurt am Main

Deutschland, Tel +496979824443

E-Mail fuezeki@sport.uni-frankfurt.de

\section{References}

BAR (2011). Rahmenvereinbarung über den Rehabilitationssport und das Funktionstraining [Framework agreement on exercise in rehabilitation and functional training]. Bundesarbeitsgemeinschaft für Rehabilitation BAR, Frankfurt am Main. http://www.kbv.de/media/sp/Rehasport_Funktionstraining.pdf, accessed 22.05.2014.

MDS (2012). Präventionsbericht 2012. Leistungen der gesetzlichen Krankenversicherung: Primärprävention und betriebliche Gesundheitsförderung. Berichtsjahr 2011 [Prevention report 2012. Performance of the statutory health insurance funds in prevention and occupational health promotion in 2011]. Medizinischer Dienst des Spitzenverbandes Bund der Krankenkassen e.V. (MDS), Essen. http://www.mds-ev.de/media/pdf/MDS_Praeventionsbericht_2012.pdf, accessed on 22.05.2014.

Smythe J., Abholz H.H., Alves B., Blane D., Borgers D. (2004): Soziale Ungleichheit im Zugang zur ambulanten Behandlung in England und Deutschland [Social inequality in access to outpatient care in England and Germany]. Zeitschrift für Allgemeinmedizin 80: 58-62.

Streich W. (2002): Qualität in der ambulanten Versorgung [Quality of outpatient care] In: Gesundheitsmonitor 2002 [Health Monitor 2002], Böcken J., Braun B., Schnee M. (eds). Bertelsmann Verlag, München. 


\title{
Physical activity promotion in primary health care in Slovenia
}

\author{
Janet Djomba ${ }^{1}$, Sanja Vrbovšek ${ }^{1}$, Breda Čuš ${ }^{1}$ \\ ${ }^{1}$ Department of Public Health, Faculty of Medicine Ljubljana/National Institute of Public Health of the Republic \\ of Slovenia
}

\begin{abstract}
In Slovenia, the role of general practitioners in counselling physical activity for prevention of cardiovascular disease (CVD) is well recognized. The role of general practitioners in advising healthy lifestyle for individuals who are at risk of developing CVD is formally defined in the National Program for Primary Prevention of Cardiovascular Disease, which has been running since 2001. Part of the program is counselling on healthy lifestyle including physical activity, performed in all health centres across the country. First a screening and medical examination is performed. In case of higher risk for CVD (>20\%) the physician should give advice on the particular risk factor and direct patients to health-education centres, where they can participate in healthy lifestyle workshops lead by health professionals. Physicians and other health professionals who are involved in the implementation of prevention activities within the program need knowledge and skills that are crucial for successful counselling on healthy lifestyle. The educational program "basic education in health promotion and prevention of chronic non-communicable diseases in primary health care/family medicine" consists of two parts. The first part of the training is open to all health professionals working within the program. The second part is intended for health professionals working in health-education workshops. In the last few years a new family practice model has been introduced and disseminated. Some duties of the family physician, including health promotion and counselling, are being transferred to graduate nurses who become part of the family practice team. This new division of work undoubtedly brings many advantages, both in terms of the work organization, and of high-quality patient care. Nevertheless preventive action cannot be fully passed on to graduate nurses. Careful planning and education are needed to ensure a comprehensive approach in healthy life style counselling.
\end{abstract}

Keywords: Physical activity, healthcare, counselling, chronic disease, prevention, Slovenia

\section{Zusammenfassung}

Die Rolle der Hausärztinnen und Hausärzte bei der Bewegungsberatung zur Vorbeugung von Herzkreislaufkrankheiten ist in Slowenien gut etabliert. Das nationale Programm zur Primärprävention von kardiovaskulären Krankheiten aus dem Jahr 2001 definiert ihre Aufgaben bei der Lebensstilberatung von Personen mit erhöhtem Risiko. Dazu gehört die Beratung für einen gesunden Lebensstil inklusive Bewegungsverhalten, die in allen Gesundheitszentren des Landes angeboten wird. Dabei wird zuerst eine Screeninguntersuchung durchgeführt. Wird bei dieser das Risiko für eine Herzkreislaufkrankheit höher als $20 \%$ eingeschätzt, bieten Ärztinnen oder Ärzte eine Beratung bezüglich der spezifischen Risikofaktoren an und überweisen die Patienten an ein Gesundheitsförderungszentrum zu einem von qualifizierten Pflegefachpersonen angebotenen Lebensstil-Workshop. Ärztinnen, Ärzte sowie Vertreterinnen und Vertreter anderer Gesundheitsberufe, die an den Präventionsaktivitäten des Programms beteiligt sind, brauchen spezifische Kenntnisse und Fertigkeiten. Das Ausbildungsprogramm «Grundausbildung in Gesundheitsförderung und Prävention nichtübertragbarer Krankheiten in der medizinischen Grundversorgung» besteht aus zwei Teilen. Der erste Teil steht allen im Programm tätigen Gesundheitsberufen offen, der zweite den in den Lebensstil-Workshops involvierten Spezialisten. In den letzten Jahren wurde ein neues Grundversorgungsmodell eingeführt und verbreitet. Dabei werden einige Aufgaben von Hausärztin und Hausarzt, darunter Gesundheitsförderung und Beratung, an Diplom-Krankenschwestern als neue Mitglieder des Grundversorgungsteams übertragen. Diese neue Arbeitsteilung bringt verschiedene Vorteile mit sich, sowohl in organisatorischer als auch in qualitativer Hinsicht. Trotzdem kann die Präventionstätigkeit nicht gänzlich an die Pflegefachpersonen delegiert werden. Sorgfältige Planung und Ausbildung sind notwendig, um einen integrierten Ansatz in der Lebensstilberatung zu realisieren.

Schlüsselwörter: Physical activity, healthcare, counselling, chronic disease, prevention, Slovenia 


\section{The tradition of health promotion in primary care}

In Slovenia, health promotion in primary health care has a long tradition and the importance of family physicians in counselling physical activity for prevention of cardiovascular disease (CVD) is well recognized (Fraz 2002a, Fraz 2002b). The role of family physicians in advising healthy lifestyle for individuals who are at risk of developing CVD is formally defined in the National Program for Primary Prevention of Cardiovascular Disease (NPPPCVD), which has been running since 2001 (Fraz et al, 2009). The target population for the NPPPCVD are women aged 45-70 years and men aged 35-65 years. Individuals within those age groups are invited from their family medicine practice every five years to attend a preventive examination. The NPPPCVD consists of two major parts: screening for CVD risk and lifestyle intervention. First a screening and medical examination (physical examination, anthropometric measurements, laboratory tests) is performed to identify individuals at risk for CVD. In case of higher risk for CVD (>20\%) the physician should give advice on the particular risk factor and direct patients to health-education centres, where they can participate in healthy lifestyle workshops (short introductory workshops and long workshops on healthy nutrition, physical activity, healthy weight loss and smoking cessation) led by health professionals. Workshops on physical activity are led by physiotherapists preferably. They consists of twelve meetings and includes demonstration and performing different kinds of exercise, continuous performance of selected exercise, motivation, individual assessment and management of potential barriers and evaluation of progress by the $2 \mathrm{~km}$ walk test performed and the beginning and the end of the workshop.

Family physicians working in the public primary health care system are obliged to carry out the screening process on their registered patients every five years. Screening for CVDs is a part of the work in family medicine practices therefore family physicians do not get additional payment for it. Workshops are performed in health education centres located in all community health centres in the country. Costs of the NPPPCVD, including screening, lifestyle interventions, national and regional coordination and maintenance of the register of people at risk for CVD, are covered by the National Health Insurance Institute. Screening, counselling and participation in healthy lifestyle workshops are free of charge for the patients.

The National Institute of Public Health (NIPH) coordinates the NPPPCVD on the national level, both the work of family physicians and the health education centres. The NIPH also carries out educational trainings for health professionals working in the program and reports to the insurance institute. Regional coordinators are responsible for coordination and communication on the local level and reporting to the national coordinator.

\section{Current developments}

Currently a new information system is being developed to assist and improve the patient's treatment within the NPPPCVD. The new IT system will improve the quality of counselling, the communication between the physician and the health education centre and follow up of patients.
Physicians and other health professionals who are involved in the implementation of prevention activities within the NPPPCVD need knowledge and skills that are crucial for successful counselling on healthy lifestyle. Educational trainings are performed continuously to assure adequate knowledge of health professionals entering the NPPPCVD. The educational program "basic education in health promotion and prevention of chronic non-communicable diseases in primary health care/family medicine" consists of two parts. The first part of the training is open to all health professionals working within the program. Participants learn about risk factors for CVDs, health promotion, behaviour change theory etc. After the training participants are able to provide counselling on healthy lifestyle and risk factor management and to perform the introductory workshops. The second part is intended for health professionals working in health-education centres. Participants learn how to lead, perform and organize the individual workshops (Cindi Slovenia 2014). Experience shows that after the first few years physicians don't attend the trainings anymore.

In the last few years a new family practice model has been introduced and disseminated (Ministrstvo za zdravje Republike Slovenije 2014). There are two important changes regarding preventive activities. First, the screening is extended to other non-communicable chronic diseases as well and the age limit is lowered to 30 years for both sexes. Second, some duties of the family physician, including screening, counselling and health promotion, are transferred to graduate nurses. They become part of the family practice team to improve the treatment of chronic patients and perform preventive measures. All graduate nurses working in those model practices have to undergo an educational training which includes modules on treatment of patients with individual NCDs and preventive measures. The module on preventive measures is carried out by the NIPH. It includes basic information about lifestyle risk factors for NCDs, screening procedures for individual NCDs, behaviour change theory and training on counselling at individual risk factors. This new division of work undoubtedly brings many advantages, both in terms of the organization of work, as well as high-quality patient care. Nevertheless preventive action cannot be fully passed on to graduate nurses, especially because most patients wish and expect advice on healthy lifestyle from their physician (Klemenc-Ketis et al., 2011).

\section{Family physicians and physical activity counselling}

Slovenian studies (Petek et al., 2013, Bulc 2006, Kersnik et al., 2009, Petek-Ster et al., 2007, Petek-Ster et al., 2005) have shown that the opinion of family physicians towards counselling on healthy lifestyle is positive. Counselling is more often provided focused on present risk factors, rather than healthy lifestyle advice to healthy individuals (Petek et al., 2013). The results of the latter study also showed that family physicians give advice on physical activity mostly as part of healthy lifestyle counselling in general.

Careful planning and education of all health professionals involved are needed to ensure a comprehensive approach in healthy life style counselling. 


\section{Corresponding author:}

Dr. med. Janet Klara Djomba, Katedra za javno zdravje Medicinska fakulteta, Univerza v Ljubljani

Zaloška cesta 4, SI-1000 Ljubljana, Slovenia

E-Mail: janet-klara.djomba@mf.uni-lj.si

Phone +386 1 543-75-46

\section{References}

Bulc M. (2006): Attitudes of Slovene general practice trainers to the implementation of preventive activities. Zdravstveno varstvo 45: 81-89.

CINDI Slovenija (2014): Ciljna populacija "Programa temeljnega izobraževanja s področja promocije zdravja in preprečevanja kroničnih nenalezljivih bolezni (KNB) v osnovnem zdravstvenem varstvu/družinsk medicini". Accessed on 24.04.14 at: http://cindi-slovenija.net/images/stories/cindi/strokovna_javnost/izobrazevanja_cindi_ciljna_populacija.pdf Fras Z. (2002a): Predpisovanje telesne aktivnosti za preprečevanje bolezni srca in ožilja [= Physical activity prescribed for prevention on cardiovascular diseases]. Zdravstveno varstvo 41 (1/2): 27-34.

Fras Z. (2002b): Telesna dejavnost- varovalni dejavnik za zdravje srca in ožilja [= Physical activity protects against cardiovascular diseases]. Zdravstveno varstvo 41 (1/2): 20-26.
Fras Z., Maučec Zakotnik J., Govc Eržen J., Luznar N. (2009): Nacionalni program primarne preventive srčno-žilnih bolezni- zgodba o uspehu? In Vrbovšek S, Luznar N, Maučec Zakotnik J, ed. Skupaj varujemo zdravjekaj smo dosegli v prvih osmih letih? (2009) Zbornik ob letnem srečanju izvajalcev Nacionalnega programa primarne preventive srčno-žilnih bolezni. Inštitut za varovanje zdravja RS, Ljubljana, p 13-26.

Kersnik J., Poplas-Susic T., Kolsek M., Svab I. (2009): What may stimulate general practitioners to undertake screening and brief intervention for excess alcohol consumption in Slovenia? A focus group study. J. Int. Med. Res. 37: 1561-1569.

Klemenc-Ketis Z., Bulc M., Kersnik J. 2011): Attitudes of Slovenian family practice patiens towards changing unhealthy lifestyle and the role of family physicians: cross sectional study (2011). Croat. Med. J.; 52: 205-211. Ministrstvo za zdravje Republike Slovenije (2014): Referenčne ambulante. Accessed on 24.04 .14 at: http://www.mz.gov.si/si/mz_za_vas/zdravstveno_ varstvo/referencne_ambulante/

Petek D., Platinovsek R., Klemenc-Ketis Z., Kersnik J (2013): Do family physicians advise younger people on cardiovascular disease prevention? A cross-sectional study from Slovenia. BMC Family Practice; 14: 82

Petek- Ster M., Kersnik J. (2005): Knowledge and acceptance of hypertension guidelines in clinical practice: experience from Slovenia. Wien. Klin. Wochenschr. 117: 534-540.

Petek- Ster M., Kersnik J., Svab I. (2007): Compliance with hypertension guidelines in general practice in Slovenia. Srp. Arch. Celok. Lek. 135: 191-196. 


\title{
Exercise in Medicine in Russia
}

\author{
Rimma Potemkina, Sergey Boytsov \\ National Research Centre for Preventive Medicine, Ministry of Health of the Russian Federation, Moscow, Russia
}

\section{Summary}

Noncommunicable diseases, mainly cardiovascular diseases and cancers, and external causes account for more than $80 \%$ of mortality in Russia. The leading causes of death and disability are directly associated with behavioural risk factors, physical inactivity being one of them. Until a few years ago, a clear standard recommendation on physical activity (PA) counselling for general practitioners did not exist in Russia. In 2010, the guidelines on physical activity counselling for primary health care providers were developed. On the basis of these guidelines the national recommendations on PA were developed in 2011. They were included in the national recommendations on Cardiovascular Prevention of the Society of Cardiology of the Russian Federation. In 2012 the guidelines were adopted by the Ministry of Health of the Russian Federation and recommended to primary health care providers of all Russian regions. One of the reasons why primary health care providers are not involved enough in counselling their patient regarding a healthy lifestyle - PA as well as smoking, healthy nutrition or other habits - is that these consultations are not covered by health insurance companies. Other barriers are the absence of the topic of a healthy life-style in pre-graduate and post-graduate curricula of medical universities as well as limited counselling skills in physicians. In 2011 an educational training course for primary health providers based on the guidelines described above was established by the National Research Centre for Preventive Medicine. The further implementation of the PA recommendations depends on the one hand on their inclusion in the curricula of medical universities and on the other hand on the creation of ways for involving and motivating primary health care providers to counsel patients in this area.

Keywords: Physical activity, healthcare, counselling, chronic disease, prevention, Russia

\section{Zusammenfassung}

Nichtübertragbare Krankheiten, insbesondere kardiovaskuläre Erkrankungen und Krebs, sowie äussere Einflüsse sind für mehr als $80 \%$ der Mortalität in Russland verantwortlich. Die wichtigsten Ursachen für Todesfälle und Behinderungen hängen direkt mit verhaltensbedingten Risikofaktoren zusammen, dazu gehört auch die körperliche Inaktivität. Bis vor wenigen Jahren gab es in Russland keine standardisierten Bewegungsempfehlungen. 2010 wurden die Richtlinien für Bewegungsberatung durch medizinische Grundversorger entwickelt, auf dieser Basis wurden 2011 auch nationale Bewegungsempfehlungen herausgegeben. Diese wurden auch in die Empfehlungen der russischen Gesellschaft für Kardiologie für die Prävention kardiovaskulärer Erkrankungen aufgenommen. 2012 wurden die Empfehlungen vom russischen Gesundheitsministerium aufgenommen und für die medizinische Grundversorgung in allen Regionen Russlands als gültig erklärt. Die Grundversorger engagieren sich bis heute noch nicht genügend in der Bewegungsberatung; ein Grund dafür ist, dass Beratungen zu einem gesundem Lebensstil - Bewegung, Nichtrauchen, gesunde Ernährung und andere Verhaltensweisen - durch Krankenversicherer nicht vergütet werden. Zudem fehlt das Thema «gesunder Lebensstil» in Curricula der Aus- und Weiterbildung der medizinischen Universitäten und die Beratungskompetenzen der Grundversorger sind noch begrenzt. 2011 wurde durch das Nationale Forschungszentrum für Präventivmedizin ein Ausbildungskurs für Grundversorger ins Leben gerufen. Die weitere Umsetzung der Umsetzungsrichtlinien hängt einerseits von deren Integration in die Ausbildung angehender Mediziner ab und andererseits davon, ob und wie es gelingt, die praktizierenden Grundversorger in die Thematik der Bewegungsberatung einzubeziehen und sie entsprechend zu motivieren.

Schlüsselwörter: Physical activity, healthcare, counselling, chronic disease, prevention, Russia 


\section{Prevailing health issues and risk behaviours}

During the last two decades the mortality rate increased in the Russian Federation from 11. 9 per 1000 in 1990 to 15.7 per 1000 in 2003 (figure 1). At the same time, the birth rate declined from 13.5 per 1000 to 10.1 per 1000 . Since 2003 mortality is declining again, but still remains significantly higher than in other parts of Europe. In 2010, life expectancy at birth was 14 years lower for Russian men than for men in the European Union (figure 1). Noncommunicable diseases, mainly cardiovascular diseases and cancers, and external causes account for more than $80 \%$ of the mortality of Russians. Cardiovascular diseases are the leading cause of premature death in men with about half of all cases as well as in women with about two thirds of all cases. The second ranking causes for premature mortality are external causes in men and cancers in women (source: Mortality indicator data-base (HFA-MDB) of the World Health Organization Regional Office for Europe, updated: April 2014; www.euro.who.int).

The leading causes of death and disability in the Russian population are directly associated with behavioural risk factors. Low levels of physical activity (PA) are an important one. A behavioural risk factor surveillance system does not exist in Russia, but several surveys on physical activity behaviour of the population have been conducted during the last decade. From 2000 to 2002 three Russian cities (Moscow, St. Petersburg and Tver City, located between the other two) conducted a random-sample survey using the International Physical Activity Questionnaire (IPAQ) (Zabina et al, 2002). In this study, less than $15 \%$ of residents reported low levels of physical activity (figure 2). At the same time, it was detected in several surveys that the high activity levels in the population were mostly attributable to walking. Mean walking time was about $80 \mathrm{~min} /$ day in men and $90 \mathrm{~min} /$ day in women (figure 3).

In 2011 the prevalence of low levels of physical activity (engaging in less than 30 minutes of moderate activity on 5 days of the week or less than 20 minutes of vigorous activity on three days of the week, or a respective equivalent) was $23 \%$ in men and 22\% in women (WHO 2011). According to the data of the Russia Longitudinal Monitoring Survey (www.hse.ru/ rlms), the average body mass index of the adult Russian Population has increased from 23.8 in 1994 to 24.5 in 2005 where it still remained in 2010. This could be also related to decreasing activity levels just as in populations of other European countries.

\section{Development of guidelines}

Traditionally, physical activity as a public health issue was was perceived in the following two ways in Russia: sport (mostly elite, striving for high achievements) or rehabilitation of patients (for example after stroke, or other diseases). Until recently there was a gap in PA promotion, particularly regarding activities for the general population and programmes for most patients. These populations were not recognized as target groups which were also in need of recommendations or physical activity counselling.

One of the reasons for this gap is the fact that clear standard recommendations on physical activity counselling for district physicians and general practitioners did not exist in Russia. In 2010 the guidelines on physical activity for primary health care providers were developed by the National Research Centre for Preventive Medicine and published in the Russian Journal for Preventive Medicine (Potemkina 2010).
Figure 1: Standardised death rate for all causes and all ages, in the Russian Federation and in the European Union, and live births in the Russian Federation in the year 1990 to 2010. All numbers are given per 1000 population. Source: European health for all data-base (HFA-DB) of the World Health Organization Regional Office for Europe, updated: April 2014 (www.euro.who.int).

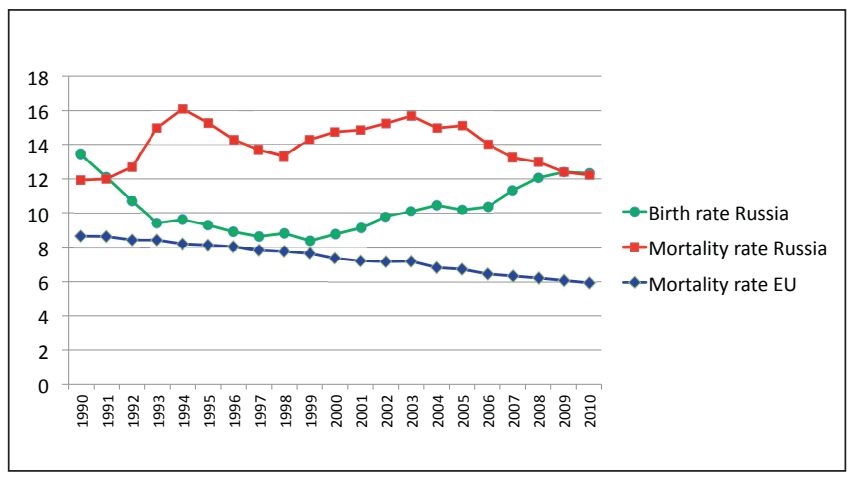

Figure 2: Prevalence of low levels of physical activity according to IPAQ data in 25-64 year olds in tree Russian cities, 2000-2002 ( $\mathrm{n}=3019)$.

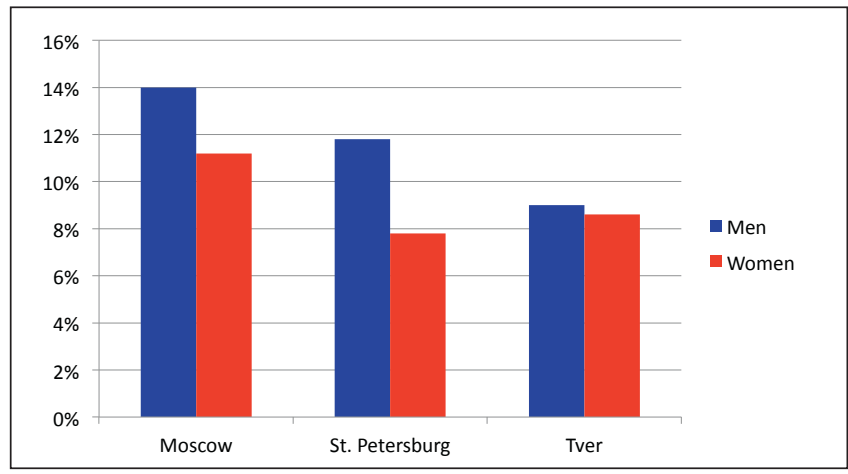

Figure 3: Age standardized daily walking time in minutes in 25-64 year olds in three Russian cities, 2002 ( $n=3722)$. Source: Russian Countywide Integrated Noncommunicable Disease Intervention Programme CINDI (http://cindi.gnicpm.ru).

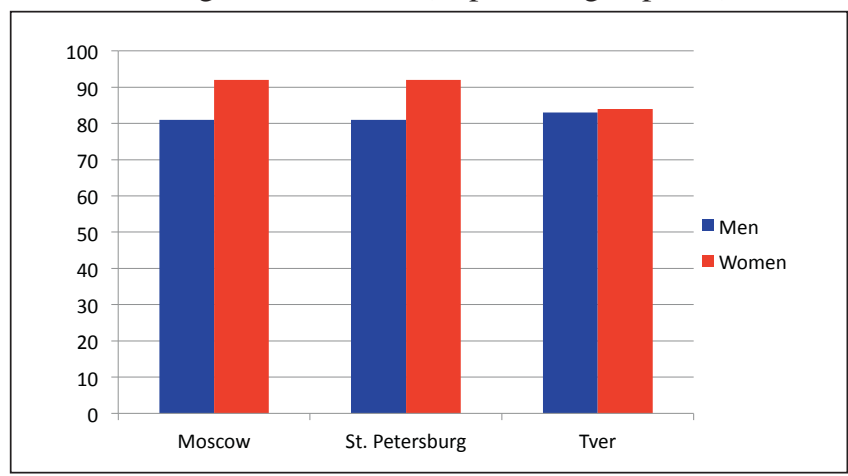

The guidelines were based on the Global Recommendations on Physical Activity for Health (WHO 2010) and included the following elements: evaluation of the patients' activity levels and their motivation, and - depending on those factors - three types of recommendations. On the basis of these guidelines, the national physical activity recommendations on PA were 

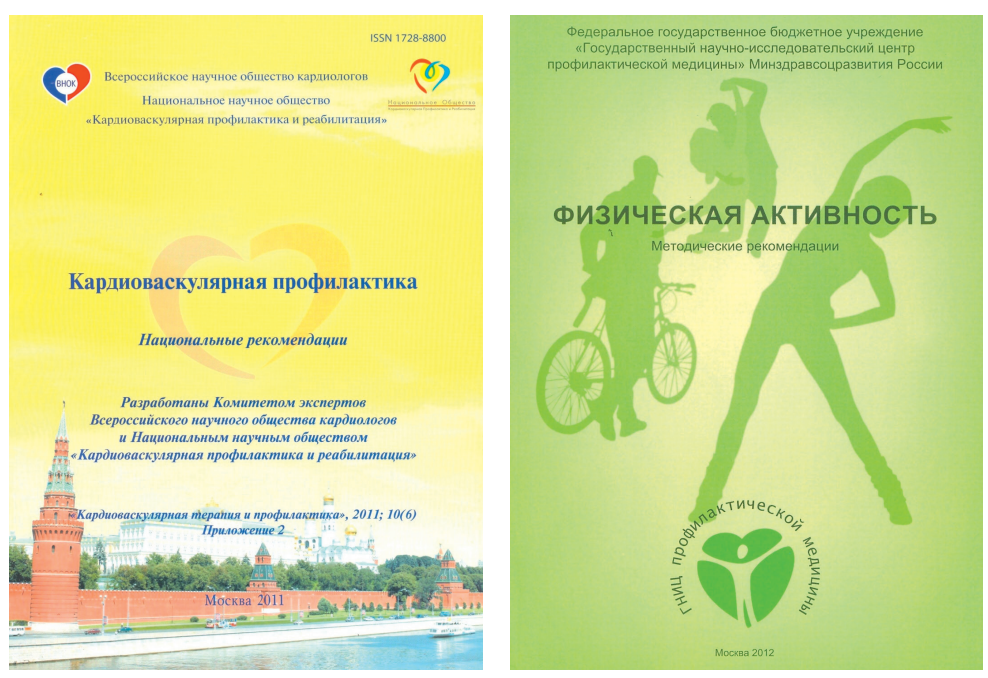

Figure 4: National Recommendations on Cardiovascular Prevention and Guidelines on Physical Activity for Primary Health Care Providers in the Russian Federation.

developed in 2011 and included in the National Recommendations on Cardiovascular Prevention of the Society of Cardiology of the Russian Federation (Cardiovascular Prevention 2011) (figure 4). In 2012, the guidelines were adopted by the Ministry of Health of the Russian Federation and recommended to primary health care providers of all Russian regions (figure 4). The National Recommendations on Cardiovascular Prevention were widely discussed among professionals and political authorities at national conferences.

\section{Training of health care providers}

The current Russian health care system was established at the beginning of the 20th century. The main principle of the system is availability and free service. Governmental health insurance (compulsory insurance) covers all residents of the country. The existing governmental health care system is based on the geographic-territorial principle. Each resident in Russia has obligatory insurance and can apply for care at the local outpatient clinic, which is typically located close to the place of residence and has a contract with the governmental insurance company. A district physician works at the outpatient clinics and provides primary health care. During the last two decades general practitioners (GPs) have started working in different regions of Russia, but until now the system of GPs is not widespread.

Since the 1990s a parallel voluntary insurance system appeared in the country, and private health structures began to develop. The system functions on an individual contract basis on health care or through the employer, typically with large commercial operations, which take care of their employees.

Until now, patient counselling in physical activity as well as in smoking cessation, healthy nutrition or other behaviours is not covered by insurance companies. This is one of the reasons why primary health care providers are not sufficiently involved in counselling their patients regarding healthy lifestyles. The absence of this topic in the pre-graduate and post graduate curricula of medical universities as well as limited counselling skills in physicans are additional barriers in this area.

In 2011, a regular educational training course based on the guidelines described above has been established by the National Research Centre for Preventive Medicine for primary health care providers. In 2012, 372 regional primary health care physicians were trained in physical activity counselling, 225 of them in a distance education course. In 2013, the training was disseminated to 1611 physicians and 44 faculties of Medical Academies from different Russian regions. Currently a protocol for the evaluation of the effectiveness of this course is being elaborated.

\section{Conclusions}

There is strong scientific evidence on the benefits of physical activity for health. International and national recommendations are available on physical activity counselling for primary health care providers. Exercise in medicine in Russia is in the process of development. The further implementation of the physical activity recommendations depends on the one hand on their inclusion in the curricula of medical universities and on the other hand on the creation of ways for involving and motivating primary health care providers to counsel patients in this area.

Corresponding author:

Dr. Rimma Potemkina, MD PhD, Head of the Department for Integrated Preventive Programs, National Research Centre for Preventive Medicine, Ministry of Health of Russian Federation, Petroverigsky pereulok 10, Moscow 101990, Russia, Tel.: +7 495628 2137, E-Mail: rpotemkina@gnicpm.ru

\section{References}

Cardiovascular prevention (2011): National recommendations. Cardiovascular therapy and prevention. 10(6). Supplement 2.

Potemkina R. (2010): Physician's counselling in physical activity (guidelines for physician of primary health care). Russian Journal of Preventive Medicine.; 3: 29-34.

WHO (2010). Global recommendations on physical activity for health. World Health Organization, Geneva.

WHO (2011): Noncommunicable diseases country profiles 2011. World Health Organization, Geneva.

Zabina H.Y., Schmid T.L., Potemkina R.A, Glasunov I.S., Deev A.D. (2002): Evaluation of Physical Activity Levels in Russia Based on the International Physical Activity Questionnaire (IPAQ). Medicine \& Science in Sport \& Exercise. 34(5): S264. 


\title{
"Exercise is Medicine" in Latin America: training health care professionals in physical activity prescription
}

\author{
John Duperly ${ }^{1,2}$, Vanessa Collazos ${ }^{2}$, Carolina Paez ${ }^{2}$, Carolina Donado ${ }^{1}$, Michael Pratt ${ }^{3}$, Felipe Lobelo $^{4}$ \\ ${ }^{1}$ Universidad de los Andes, Medical School, Fundación Santa Fé de Bogotá, Colombia \\ 2 "Exercise is Medicine" Latin American Regional Center, Bogota, Colombia \\ ${ }^{3}$ National Center for Chronic Disease Prevention and Health Promotion, Centers for Disease Control and Prevention, \\ Atlanta, Georgia, USA \\ 4 "Exercise is Medicine" Global Center, Indianapolis, Indiana, USA
}

\begin{abstract}
Health care professionals (HCPs) play an important role promoting healthy habits to patients, yet they lack knowledge, training and self-efficacy to effectively prescribe physical activity (PA).

In 2011, the "Exercise is Medicine" Latin American Regional Center developed a one-day (8 hours) in-person course on PA and exercise prescription for HCPs, with theoretical and practical components. Contents include evidence-based health benefits of PA, screening for major risk factors, key behavioral change strategies, basic exercise testing, and prescription and referrals principles.

Participants take a multiple-choice evaluation before and after the training. Those who score $80 \%$ or higher in the final evaluation receive an international certification endorsed by the American College of Sports Medicine. Since 2013, they also report current PA habits and counselling in clinical practice at the beginning of the course. Sustainability of this initiative, including free enrollment of participants, has been achieved with the support from the industry, scientific societies, and sports and exercise authorities.

As of October 2013, 40 courses have been carried out in 15 cities and 7 countries of the region. A total of $1206 \mathrm{HCP}$ have participated $(26.4 \%$ general practitioners, $47.8 \%$ specialists, $20 \%$ other HCP), and 625 physicians have been certificated. Participants scored, on average, $20 \%$ higher in the final versus the initial evaluation.

In total, 379 participants completed the questionnaire, $61.2 \%$ of which reported to currently comply with international PA level recommendations. Also, 52.2\% and 57.5\% reported to always assess or recommend PA in their clinical practice. The overall quality of the course was scored 4.5 out of 5. Participants have shared personal testimonies, stating the positive impact of the training experience on their own personal exercise habits and clinical practice.

This course is a promising strategy to help incorporate PA promotion in health care settings. Evaluation of its medium and long-term impact is in progress.
\end{abstract}

Keywords: Physical activity, healthcare, counselling, chronic disease, prevention, Latin America

\section{Zusammenfassung}

Ärzte und andere Fachpersonen der Gesundheitsversorgung spielen eine wichtige Rolle, wenn es darum geht, gesundes Verhalten der Patienten zu fördern. Oft fehlen ihnen aber Wissen, Training und Selbstvertrauen, um wirksam Bewegung zu «verschreiben».

Das «Exercise is Medicine» Latin American Regional Center entwickelte 2011 einen eintägigen Kurs zur Verschreibung von Bewegung. Die theoretischen und praktischen Kursteile beinhalten die Gesundheitsnutzen von Bewegung, Screening für Risikofaktoren, Strategien zur Verhaltensänderung, Belastungstests und die Prinzipien von Verschreibung von Bewegung respektive weiterer Überweisung der Patienten.

Die Kursteilnehmer füllen vor und nach der Ausbildung einen Test aus. Teilnehmer, die nach dem Kurs mindestens $80 \%$ der maximalen Punktzahl erreichen, erhalten das internationale Zertifikat des American College of Sports Medicine. Seit 2011 berichten die Teilnehmer am Anfang des Kurses auch über ihr eigenes Bewegungsverhalten und ihre Beratungspraxis. Das Kursangebot mit Gratisteilnahme konnte nachhaltig gesichert werden dank Unterstützung durch private und öffentliche Partner und wissenschaftliche Gesellschaften.

Bis Oktober 2013 wurden 40 Kurse in 15 Städten und 7 Ländern durchgeführt. 1206 Personen nahmen teil (26.4\% Allgemeinpraktiker, $47.8 \%$ Spezialärzte, $20 \%$ andere Fachpersonen) und 625 Ärzte wurden zertifiziert. Die Teilnehmer erreichten nach dem Kurs $20 \%$ mehr Punkte als vor dem Kurs.

Insgesamt füllten 379 Personen den Fragebogen zum eigenen Verhalten aus. $61.2 \%$ erfüllten die Bewegungsempfehlungen. $52.2 \%$ und $57.5 \%$ gaben an, dass sie in der Praxis immer das Bewegungsverhalten erfragen beziehungsweise Bewegung empfehlen. Die Kursqualität wurde mit 4.5 von 5 Punkten beurteilt. Gemäss Rückmeldungen der Teilnehmer hatte der Kurs einen positiven Effekt auf ihr eigenes Verhalten und ihre Beratungspraxis.

Dieser Kurs ist ein vielversprechender Ansatz zur Integration der Bewegungsförderung in der Gesundheitsversorgung. Die Evaluation der mittel- und langfristigen Effekte ist in Arbeit.

Schlüsselwörter: Physical activity, healthcare, counselling, chronic disease, prevention, Latin America 


\section{Introduction}

The prevalence of noncommunicable diseases (NCDs) has reached epidemic proportions and they are quickly becoming the 21rst century's main public health challenge for all nations (Blair 2009, Ezzati et al., 2013). The World Health Organization estimated that, in 2008, 36 million global deaths were due to NCDs and $80 \%$ of them occurred in low resources regions like Latin America. Low- and middleincome countries (LMICs) of Latin America are now facing the simultaneous burden of NCDs and the unsolved issues of infectious diseases, malnutrition and maternal and child health (WHO, 2011). Thus, the epidemic of NCDs in Latin America embraces different characteristics that require special actions (López-Jaramillo 2008).

Physical inactivity, together with smoking, unhealthy diets and harmful use of alcohol constitute the main shared risk factors for developing NCDs. Physical inactivity by itself is the fourth leading cause of global mortality, responsible for approximately 3.2 million deaths annually (Kohl $3^{\text {rd }}$ et al., 2012, WHO 2011, Lee et al., 2012) and 43\% of adults are already physically inactive in the Americas (Hallal et al., 2012). A multi-stakeholder approach with interventions at all levels of society and across different sectors is needed in order to maximize the health impact of physical activity (PA) (WHO 2009; Colbert et Jangi, 2013, WEF 2013).

Primary care constitutes a key setting for the promotion of PA for the prevention and treatment of diseases (Orrow et al., 2012, Lopez-Jaramillo et al., 2013, Naci et Ioannidis, 2013). Moreover, PA has the same or better effects in the treatment of NCDs than pharmacology therapy (Naci and Ioannidis, 2013). Health care professionals (HCPs) have the responsibility to counsel and support their patients to become physically active. Similarly, when having active lifestyles, HCPs become exemplary role models to the community and are likely to provide better and more motivating counselling (Lobelo et al, 2009, Matheson et al., 2011). However, HCPs lack the appropriate knowledge, skills and self-efficacy to effectively prescribe PA and exercise to patients (Duperly et al., 2008, Lianov et Johnson, 2010, Hébert et al., 2012, Greig et al., 2013).

The American College of Sports Medicine (ACSM) created the "Exercise is Medicine" (EIM) global initiative to position PA as a vital sign within clinical settings so that PA is assessed and prescribed to every patient, in every visit, at any time (Sallis 2009). The EIM Latin American regional center developed the Exercise Prescription course for HCPs to contribute to continuing medical education training in PA prescription. Other EIM activities performed in Latin America include actions with local governments, private industry, academia and media (EIM LATAM 2013). This report describes the development, implementation and initial impact of the one-day, in-person Exercise Prescription course for HCPs in Latin America.

\section{Development of the Exercise Prescription course for HCPs in Latin America}

One of the main focuses of the EIM Latin American regional center has been the development and implementation of educational strategies in the region. The one-day ( 8 hours), in-person Exercise Prescription course has been the strategy most implemented and accepted within the region. The course contents are based on EIM-ACSM manuals and materials that include PA international guidelines and recommendations.

The course has two components, one theoretical and one practical, each of approximately 4 hours of duration. The theoretical component consists of three main lectures:

1) Health benefits and risks associated with PA: it summarizes the available and updated evidence about the health benefits and risks of regular PA practice in the general population and in people with specific conditions or diseases.

2) Screening and risk stratification: it addresses the different methods of cardiovascular risk assessment before exercise prescription, including clinical- and health-related physical fitness testing. Additionally, key strategies for effective counselling, behavioural change and motivation mobilization are highlighted.

3) General principles of exercise prescription: it addresses the key principles of exercise prescription including recommendations on different types of exercises and adequate techniques.

The practical component allows participants to consolidate their knowledge and apply all the theoretical principles. Throughout this section participants get in couples and play the roles of patient and counsellor. They learn and practice how to perform a general fitness assessment, which includes measuring blood pressure, resting heart rate, blood glucose and anthropometric indicators (e.g. weight, height, fat percentage and abdominal perimeter); cardiorespiratory fitness level is assessed through the Six-Minute Walk test; strength is measured with abdominals and push-ups tests; finally, flexibility is measured by a modified version of the well-known sit and reach test. At the end of this section, participants complete a cardiovascular risk assessment and PA prescription of their working partner.

Participants are evaluated before and after the course with a 20-questions multiple-choice exam on basic PA topics. Those who score $80 \%$ or higher in the exam after the course, receive an International Certification in Exercise Prescription endorsed by the ACSM. Even though the course was initially designed exclusively for physicians, participation of other HCPs (e.g. physical therapist, physical educators, and nutritionists) has been allowed but without the possibility of receiving the international certification.

Additionally, since 2013 participants fill out a brief survey at the beginning of the course about their current PA personal habits (i.e. short version of the International Physical Activity Questionnaire) and clinical practice (i.e. 5-point Likert scale about how frequently they assess and prescribe PA to their patients). Participants are also asked to anonymously report their satisfaction with the course, more specifically on the content of the lectures, the applicability and utility of theoretical and practical components, and general logistics.

Sustainability of the Exercise Prescription course, as well as other EIM activities in the Latin American region, has been achieved with the support from the private industry, alliances with scientific societies, governmental entities, and sports and exercise authorities. This joint effort has allowed the free enrolment of participants to the courses.

\section{Results of the Exercise Prescription course for HCPs in Latin America}

As of October 2013, a total of 40 courses have been delivered in 7 countries and 1206 HCPs have been trained (table 1). 
Table 1: Number of courses and participants per country

\begin{tabular}{lccc}
\hline Country & $\begin{array}{l}\text { Number } \\
\text { of Courses }\end{array}$ & \multicolumn{2}{c}{$\begin{array}{l}\text { Participants from } \\
\text { each country }\end{array}$} \\
\cline { 3 - 4 } & & Number & Percentage \\
\hline Argentina & 1 & 26 & $2.2 \%$ \\
Chile & 4 & 42 & $3.5 \%$ \\
Colombia & 21 & 624 & $51.7 \%$ \\
Mexico & 6 & 192 & $15.9 \%$ \\
Paraguay & 2 & 97 & $8.0 \%$ \\
Uruguay & 2 & 61 & $5.1 \%$ \\
Venezuela & 4 & 164 & $13.6 \%$ \\
Total & 40 & 1206 & \\
\end{tabular}

Among participants, $26.4 \%$ were general practitioners, $47.8 \%$ were specialists and $20 \%$ were other HCPs. The main medical specialties represented were internal medicine, cardiology, family medicine, and sports medicine (table 2).

Participants scored, on average, $20 \%$ higher in the final versus the initial exam. From the 894 physicians that attended the course, 625 received the international certification. On the other hand, 379 participants completed the survey about current PA personal habits and clinical practice. Surprisingly, $61.2 \%$ of them reported to currently engage in 150 minutes or more of moderate to vigorous PA during the week. Similarly, $52.2 \%$ and $57.5 \%$ reported to always assess or recommend PA in their clinical practice.

The overall course was qualified on average with 4.78 out of 5 points. All specific components of the course were scored above 4.5 out of 5 points (Table 3). Participants have shared personal testimonies, stating the positive impact of the training experience on their own personal exercise habits and clinical practice.

\section{Discussion}

The Latin American community is in need of HCPs who can effectively deliver PA and exercise prescription to their patients. The Exercise Prescription course developed by the EIM Latin American regional center has been a wellaccepted and highly rated initiative by hundreds of HCPs in Latin America. The strong theoretical basis added to the highly practical components of the course, all adapted to the specific necessities of HCPs, accounts for much of its success until now. The successful implementation of this strategy keeps motivating other countries and sectors to adopt it and fund it, respectively.
Table 2: Profession of course participants $n=1206$

\begin{tabular}{lc}
\hline Health care professionals (HCPs) & Participation $(\%)^{*}$ \\
\hline Medical HCPs & \\
General practitioners & $26.4 \%$ \\
Internal medicine & $10.0 \%$ \\
Cardiology & $4.6 \%$ \\
Family medicine & $4.6 \%$ \\
Sports medicine & $4.4 \%$ \\
Others & $24.3 \%$ \\
& \\
Other HCPs & \\
Physical education & $5.6 \%$ \\
Nutrition & $4.2 \%$ \\
Physical therapy & $3.8 \%$ \\
Others & $6.3 \%$ \\
\hline
\end{tabular}

* Missing data corresponds to $5.8 \%$ of total participants

The results of the course are satisfactory, with an average improvement of $20 \%$ in PA and exercise prescription knowledge. At this point it is important to remark that most attending participants join voluntarily and have a higher interest in PA compared to other peers. This could explain the unexpectedly high levels of PA among participants, and the high percentage reporting to have assessed and prescribed PA before attending the course.

Nonetheless, as the initiative continues to grow, expectations are set to reach a larger group of HCPs in the region so that a network of PA counsellors is built to facilitate referrals within primary care settings.

\section{Conclusions and further steps}

The Exercise Prescription course is a promising strategy to help incorporating PA promotion in the health care settings of Latin America, enhancing the adoption of an active lifestyle by the general population. The evaluation of the course medium and long-term impact is in progress. Likewise, the EIM regional center is developing versions of the course for other specific HCPs beside physicians.

\section{Corresponding author:}

John Duperly, MD, PhD, Latin America Exercise is Medicine Regional Center Director, Associate Professor Universidad de los Andes Medical School, Fundación Santa Fé de Bogota, Colombia E-Mail: john.duperly@ama.com.co

Table 3: Participants' qualification of the course components

\begin{tabular}{ll}
\hline Course component Qualification * & \\
\hline Overall course & \\
Overall lectures & 4.5 \\
Lecture 1 & 4.8 \\
Lecture 2 & 4.8 \\
Lecture 3 & 4.8 \\
Exercise prescription activity & 4.8 \\
Concordance between the theoretical and practical components & 4.7 \\
Pertinence and applicability of the course in their clinical practice & 4.7 \\
Usefulness of hand-out materials & 4.9 \\
Accomplishment of program and scheduled activities & 4.8 \\
Organization and logistics & 4.7
\end{tabular}

\footnotetext{
* Maximum score was 5 points
} 


\section{References}

Blair S.N. (2009): Physical inactivity: the biggest public health problem of the 21 st century. Brit J Sport Med. 43: (1): 1-2.

Colbert J.A., Jangi S. (2013): Training physicians to manage obesity - back to the drawing board. N Engl J Med. 369 (15): 1389-1391.

Duperly J., Segura, C. Herrera D.M. (2008): Medical Student's Knowledge on Physical Activity Counselling is Associated with their Physical Activity Levels. Med Sci Sport Exer. 40 (5): 251.

EIM LATAM (2013): Exercise is Medicine, Centro Regional para América Latina, Reporte de Actividades 2010-2013. Bogotá DC.

Ezzati M., Riboli E. (2013): Behavioral and Dietary Risk Factors for Noncommunicable Diseases. N Engl J Med. 369 (10): 954-964.

Greig A, Dawes D., Murphy S., Parker G., Loveridge B. (2013): Program evaluation of a model to integrate internationally educated health professionals into clinical practice. BMC Med Educ. 13 (1) 140

Hallal P.C., Andersen L.B., Bull F.C., Guthold R., Haskell W., Ekelund U. and the Lancet Physical Activity Series Working Group. (2012): Global physical activity levels: surveillance progress, pitfalls, and prospects. Lancet. 380: 247-257.

Hébert E.T., Caughy M.O., Shuval K. (2012): Primary care providers' perceptions of physical activity counselling in a clinical setting: a systematic review. Brit J Sport Med. 46 (9): 625-631.

Kohl $3^{\text {rd }}$ H.W., Craig C.L., Lambert E.V., Inoue S., Alkandari J.R., Leetongin G., Kahlmeier S. and the Lancet Physical Activity Series Working Group. (2012): The pandemic of physical inactivity: global action for public health. Lancet. 380: 294-305.

Lee I.M., Shiroma E.J., Lobelo F., Puska P., Blair S.N., Katzmarzyk P.T. and the Lancet Physical Activity Series Working Group. (2012): Effect of physical inactivity on major non-communicable diseases worldwide: an analysis of burden of disease and life expectancy. Lancet. 380: 219-229.

Lianov L., Johnson M. (2010): Physician competencies for prescribing lifestyle medicine. JAMA. 304(2): 202-203.
Lobelo F., Duperly J., Frank E. (2009): Physical activity habits of doctors and medical students influence their counselling practices. Br J Sport Med. 43 (2): 89-92.

Lopez-Jaramillo P., Sánchez R.A., Diaz M., Cobos L., Bryce A., Parra Carrillo J.Z., Lizcano F., Lanas F., Sinay I., Sierra I.D., Peñaherrera E., Bendersky M., Schmid H., Botero R., Urina M., Lara J., Foss M.C., Márquez G., Harrap S., Ramírez A.J., Zanchetti A. and the Latin America Expert Group. (2013): Latin American consensus on hypertension in patients with diabetes type 2 and metabolic syndrome. J Hypertens. 31 (2): 223-238.

Lopez-Jaramillo P. (2008): La epidemia de las enfermedades cardiometabólicas en latinoamérica: características diferentes que acciones particulares. Revista Colombiana de Cardiología. 15: 153-160.

Matheson G.O., Klügl M., Dvorak J., Engebretsen L., Meeuwisse W.H., Schwellnus M., Blair S.N., van Mechelen W., Derman W., Börjesson M., Bendiksen F., Weiler R. (2011): Responsibility of sport and exercise medicine in preventing and managing chronic disease: applying our knowledge and skill is overdue. Br J Sport Med. 45 (16): 1272-1282.

Naci H., Ioannidis J.P.A. (2013): Comparative effectiveness of exercise and drug interventions on mortality outcomes: metaepidemiological study. BMJ. 347: f5577.

Orrow G., Kinmonth A.L., Sanderson S., Sutton S. (2012): Effectiveness of physical activity promotion based in primary care: systematic review and meta-analysis of randomised controlled trials. BMJ. 344: e1389.

Sallis R.E. Exercise is medicine and physicians need to prescribe it! Br J Sport Med. 43 (1): 3-4.

WEF (2013). Charter for Healthy Living. World Economic Forum,Geneva WHO (2009): 2008-2013 Action plan for the global strategy for the prevention and control of noncommunicable diseases. World Health Organization, Geneva.

WHO (2011): Global status report on noncommunicable diseases 2010 . World Health Organization, Geneva. 


\title{
Physical Activity Promotion in Health Care Settings: the "Exercise is Medicine" Global Health Initiative Perspective
}

\author{
Felipe Lobelo $^{1}$, Jürgen M. Steinacker ${ }^{2}$, John Duperly ${ }^{3}$, Adrian Hutber ${ }^{4}$ \\ ${ }^{1}$ Exercise is Medicine Global Research Center, American College of Sports Medicine, Indianapolis, USA \\ ${ }^{2}$ European Exercise is Medicine Regional Center, University of Ulm, Germany \\ ${ }^{3}$ Latin America Exercise is Medicine Regional Center, Universidad de los Andes Medical School, Bogota, Colombia \\ ${ }^{4}$ Exercise is Medicine, American College of Sports Medicine, Indianapolis, USA
}

\section{Summary}

Physical inactivity constitutes the fourth leading cause of death globally. Health systems are being called to respond to the epidemic of non-communicable diseases (NCDs) and help deliver on the promise of prevention approaches. Substantial evidence exists in support of multi-prong physical activity counseling, prescription and referral strategies, in particular those linking clinical and community-based resources, to help increase physical activity (PA) levels. In late 2007, the "Exercise is Medicine" (EIM) initiative was established by the American College of Sports Medicine to institutionalize PA promotion into the US healthcare system. Within two years, representatives from scientific, public health and medical associations of several countries suggested to begin a multinational collaboration to make EIM a global health initiative (EIM-GHI). As such EIM-GHI's mission expanded to building a global awareness and infrastructure to drive the implementation of evidence-based strategies for PA promotion in healthcare settings. Between 2010 and 2013, EIM has developed a presence in 39 countries and seven EIM regional centers (RC) have been established in North America, Latin America, Europe, Africa, Southeast Asia, China, and Australasia, with each RC responsible for coordinating EIM-related activities in its region. The EIMGHI has taken a multisectorial approach to establishing EIM National Task Forces (NTF) in each country, to coordinate activities in 5 EIM focus areas: education \& training, policy $\&$ surveillance, clinical \& community integration, sustainability \& outreach, and research \& evaluation. Each NTF is composed of representatives from a variety of stakeholders from health care and public health, with close collaboration with media and industry partners encouraged. Broad implementation of PA prescription and referral systems as a global standard of care, integrating health care and community PA services, has the potential to improve PA at the population level and to contribute to achieving global targets for the reduction of inactivity and NCD morbidity and mortality.

Keywords: Physical activity, healthcare, counselling, chronic disease, prevention and control

\section{Zusammenfassung}

Bewegungsmangel ist weltweit der viertwichtigste Risikofaktor für frühzeitige Todesfälle. Gesundheitssysteme sollten auf die Epidemie der nichtübertragbaren Krankheiten reagieren und Beiträge zu deren Prävention leisten. Es gibt gute Evidenz, dass Strategien der Bewegungsberatung oder -verschreibung helfen, das Bewegungsverhalten zu verbessern insbesondere Ansätze, die klinische und gemeindebasierte Ressourcen verbinden. 2007 wurde «Exercise is Medicine» (EIM) durch das American College of Sports Medicine lanciert, um Bewegungsförderung im Gesundheitswesen der USA zu institutionalisieren. Nach zwei Jahren schlugen Vertreter von Wissenschaft, Public Health, medizinischen Gesellschaften und mehreren Ländern vor, international zusammenzuarbeiten, um EIM in eine globale Gesundheitsinitiative überzuführen. Die Mission dieser Initative wurde somit, global Bewusstsein und Strukturen aufzubauen, um die evidenzbasierte Integration von Bewegungsförderung in der Gesundheitsversorgung voranzutreiben. Zwischen 2010 und 2013 würde EIM in 39 Ländern eingeführt und 7 regionale Zentren wurden eingerichtet, in Nordamerika, Lateinamerika, Europa, Afrika, Südostasien, China und Australien/ Ozeanien. Jedes regionale Zentrum ist verantwortlich für die Koordination der EIM-Aktivitäten in seiner Region. Die globale EiM-Gesundheitsinitiative richtete in jedem Land eine nationale EIM Task Force ein, welche die fünf EIM Schwerpunktaktivitäten koordiniert: Ausbildung, Policy und Monitoring, Integration klinischer und gemeindebasierten Ressourcen, Nachhaltigkeit und Reichweite, Forschung und Evaluation. Zu den nationalen Task Forces gehören Vertreter aus Klinik und Public Health, und eine enge Zusammenarbeit mit Medien und Partnern aus der Industrie ist empfohlen. Eine breite Umsetzung der Ansätze von EiM im Sinne eines globalen Standards in der Gesundheitsversorgung sowie die Integration von klinischen und gemeindebasierten Leistungen haben das Potential, das Bewegungsverhalten auf Bevölkerungsebene zu verbessern und damit global zur Reduktion der Last der nichtübertragbaren Krankheiten beizutragen.

Schlüsselwörter: Physical activity, healthcare, counselling, chronic disease, prevention and control 


\section{Introduction}

Physical inactivity now constitutes the fourth leading cause of death worldwide (WHO 2009), responsible in 2010 for about 5 million deaths, or $9 \%$ of the total global premature mortality due to major non-communicable diseases (NCDs) (Lee et al, 2012). Given its high prevalence - a third of the global population does not meet current recommendations (Hallal et al, 2012) - as well as the health and economic burden (Pratt et al, 2012), promotion of physical activity (PA) has recently been selected by health and government authorities as one of the top priority strategies in the global fight against the NCD epidemic (WHO 2013a; WHO 2013b). In this context, health systems around the world are being called to respond and help deliver on the promise of prevention approaches (WHO 2004).

Primary care health systems should play a prominent role to help deliver NCD preventive strategies such as PA promotion (Heath et al, 2012, GAPA 2010, Patrick et al, 2009). Several different strategies have been used to implement PA promotion in the health care settings. Brief PA advice, initiated by the physician or another health care provider, in the context of the primary care setting, has been a commonly used strategy (Simons-Morton et al, 2001). Approaches deploying advice plus written PA prescriptions, behavioral change and follow-up tools, also known as "green prescriptions", have also been used (Swinburn et al, 1998). As a response to commonly encountered barriers to effectively integrate PA counseling in routine clinical practice, more recent efforts have focused in establishing systems or PA referral schemes where clinicians screen inactive individuals (PA assessment), provide a brief PA counseling/prescription and then refer their patients to community-based PA resources (Murphy et al, 2012, Leijon et al, 2008, Malta et al, 2012).

There is substantial and growing evidence in support of each of these PA promotion approaches, in particular multi-prong PA counseling, prescription and referral strategies linking health care and community-based resources to help increase PA levels (Lin et al, 2010, Williams et al, 2007). For example, a review of 13 trials including brief PA advice and "green prescription" approaches (Pavey et al, 2011), saw small to medium positive intervention effects at 12 months (odds ratio 1.42, 95\% confidence interval 1.17 to 1.73 ). The number needed to treat for one additional sedentary adult to meet internationally recommended levels of activity at 12 months was 12 (C.I. 7 to 33). PA referral schemes in primary care have also shown modest efficacy. In a recent review (Orrow et al, 2012), compared with usual care, follow-up data for exercise referral schemes showed an increased number of participants who achieved 90-150 minutes of physical activity of at least moderate intensity per week (pooled relative risk $1.16,95 \% \mathrm{CI}$ 1.03 to 1.30 ) and a reduced level of depression (pooled standardised mean difference $-0.82,-1.28$ to -0.35 ).

The "Exercise is Medicine" (EIM) initiative was introduced to help catalyze the broad implementation of evidence-based approaches to promote PA in health care settings (Sallis 2009, Sallis 2011). In this report, we describe the perspective of the EIM initiative to continued work in this area around the world.

\section{The Launch and Globalization of the "Exercise is Medicine" Health Initiative}

EIM (www.exerciseismedicine.org) was cofounded in late 2007 by Ronald Davis and Robert Sallis, presidents of the
American Medical Association (AMA) and the American College of Sports Medicine (ACSM) respectively. EIM's original mission was to institutionalize the scientifically proven benefits of PA into the US healthcare system. However, within two years of EIM's US launch and the establishment of an EIM Center (EIMC) at ACSM's Indianapolis-based headquarters, representatives from scientific, public health and medical associations of several countries had requested that EIMC expand its initial scope beyond the USA and begin a multinational collaboration to make EIM a global effort. Thus, in 2010, the EIMC was renamed the EIM Global Center (EIMGC) and EIM's mission expanded to one of building a global awareness and infrastructure to implement PA promotion in healthcare settings, with a particular focus on physicians and other health care providers (HCPs). In its initial three year globalization period (2010-2013), EIMGC's primary strategy was to identify a key country in each of EIM's designated "regions" in which to establish an EIM Regional Center (RC). The seven RCs are in North America, Latin America, Europe, Africa, Southeast Asia, China, and Australasia. The EIM initiative has also recently been launched in several Middle Eastern countries. Each RC is responsible for coordinating EIM-related activities in its region and, when feasible and appropriate, for supporting the establishment and continued growth of EIM in other countries in its region. The EIMGC and RCs then determined key countries within each region to initially target to launch EIM. Criteria considered included the likely receptivity of a targeted country's healthcare system to the changes proposed by EIM, and the infrastructure and policies of a targeted country's healthcare system. This approach has been highly successful in spreading the EIM initiative globally and, by September 2013, EIM has developed a presence in 39 countries.

The EIMGC has taken a multi-sectoral approach to establishing EIM National Task Forces (NTFs) in a country. Each NTF is composed of representatives from a combination of the country's national primary care and other medical associations (Cardiology, Endocrinology, Sports Medicine, Nursing, Nutrition/Dietetics, Physical Therapy), Physical Education, academic institutions, and when possible, the Ministry of Health or National Public Health Institute. Close collaboration with media and industry partners and leveraging the expertise that they provide in key areas, such as public messaging, has also seen as critical and has been highly encouraged. The EIMGC identified and established a relationship with a key partner institution in each country where the RC and/or NTF was to be based. These institutions were a professional medical/ science association, a university, or a prominent medical system.

Whilst the initial phase of the EIM Global Health Initiative (2010-2013) focused on raising awareness for the importance of integrated PA promotion in healthcare and the establishment of NTFs, the second phase of the EIM initiative will revolve around the implementation of the EIM "Solution". The EIM Solution is, in essence, the integration of clinical healthcare provider services with community evidence-based PA programs. The aim of these two key activities is to embed a physical activity vital sign (PAVS) (Coleman et al, 2012) into electronic medical records (EMRs), to develop a national network of evidence-based community PA programs and resources, and to provide a clinical decision support system linking the two, so that HCPs can provide behavioral PA counseling and refer patients to fulfill their PA "prescription" in the community. It is, however, also essential, that the clinical and 
community integration activities are augmented by carefully targeted activities in the areas of policy and surveillance, evaluation, HCP and fitness professional education (http:// certification.acsm.org/exercise-is-medicine-credential), and media and industry support. Without these additional focus areas, most countries are unlikely to spark the necessary institutional and personal impetus for healthcare systems and HCPs to break the barriers that impede the integration of clinical-community linkages for PA promotion. But these systemic changes have the potential to bring about increases in PA at the population level. Although the EIM Solution will undoubtedly need to be customized to the individual needs of a country, it is likely to provide a useful model on which each NTF can build a platform.

\section{"Exercise is Medicine" throughout the Globe}

\section{Africa}

The African region faces a unique challenge. Because of its double burden of infectious and non-communicable disease, the EIMGC decided to adopt a different strategy for this region by seeking opportunistic (rather than targeted) partnerships with African countries that judged themselves ready to be part of EIM's focus on NCDs.

EIM's RC in Africa is located in Johannesburg, South Africa and managed through a strategic partnership with the South African Sports Medicine association. EIM currently has a presence in Ghana and Kenya. This region's initial primary focus is on building awareness in, educating, and accrediting healthcare professionals (HCPs) and (health/fitness professionals (FPs), together with EIM-related public health promotion and research coordination.

\section{Australasia}

The Australasian RC is located in Brisbane, Australia and managed through a strategic partnership with Exercise and Sports Science Australia. Three key areas of this region's strategy include PA in healthcare related policy and advocacy, education and training of HCPs and FPs, and PArelated research. The Australasian RC has also assumed a leadership role for PA in the Australian workplace and released "Physical Activity in the Workplace: A Guide" (www.exerciseismedicine.org.au/active-workplaces).

\section{China}

The Chinese RC is located in Beijing and managed through a strategic partnership with the International Life Sciences Institute Focal Point in China, based in the Chinese Center for Disease Control and Prevention. China's initial strategy has centered on education. Physician training courses have been and continue to be conducted at major medical conferences in cooperation with the Chinese Society of Cardiology.

\section{Europe}

The RC for Europe based in Ulm, Germany has already formed the "European Initiative for Exercise in Medicine" (EIEIM) an non-profit organization of European task forces and supporting members. In an initial meeting of 18 nations in Cascais, Portugal in 2011, a founding board was determined and eight members signed the founding statues on June $27^{\text {th }} 2013$ in Barcelona. European countries involved with EIEIM include Austria, Czech Republic, Germany, Hungary, Norway, Portugal, Slovakia, Spain, Sweden, Switzerland, and the United Kingdom. EIEIM is recognized by the European College of Sports Science and HEPA Europe (Martin-Diener et al, 2014). Within Europe, public health and clinical researchers have longstanding achievements incorporating PA counseling for the prevention and sports medicine fields. Europe has in total 53 nations with a variety health care systems from public to private-based health insurances. In Europe, sports are often organized in club systems and professional sports partners have grown but have different importance in each country. EIEIM respects these country differences and autonomy but provides a continental framework for supporting its members promote PA counseling in the health care settings. EIEIM is also approaching the European Commissions' Sports Unit in the Directorate General for Education and Culture (DG EAC) and the European Parliament to help advance these goals. EIEIM has organized two European EIM congresses, 2012 in Berlin and 2013 in Frankfurt, in conjunction and with generous support of the German Association for Sports Medicine and Prevention.

\section{Latin America and the Caribbean}

The Latin American RC is located is in Bogota, Colombia, managed through the EIMGC's strategic partnership with the University of Los Andes. Other EIM countries within the region include Argentina, Aruba, Brazil, Chile, Costa Rica, Ecuador, Mexico, Paraguay, Uruguay, and Venezuela. This region's primary focus is on educating and accrediting HCPs through a training course that is offered one weekend per month in Bogota, as well as in other Latin American countries, throughout the year. Special emphasis is being given to educating both primary care and sub-specialists in a "train the trainer" model, because these physicians are key influencers within the healthcare system and are well placed to training other primary care physicians within their geographical locale. The EIMGC and Latin American RC worked with the Aruban Minister of Health and Sports in 2013 to make Aruba the first country to officially adopt the EIM Global Health Initiative as part of a national collaboration (Duperly et al, 2014).

\section{Middle East}

Although there is not yet an EIM RC in the Middle East, EIM has been launched in several Middle Eastern countries, including Israel, Kuwait, Lebanon, Turkey and the United Arab Emirates. Initial efforts in these countries are focused on educating and training HCPs how to integrate PA assessment and counseling or referral into healthcare.

\section{Southeast Asia}

The RC for the Southeast Asian region is located in Singapore and managed through the EIMGC's strategic partnership with Changi hospital. Other EIM countries within the region include Indonesia, Malaysia, the Philippines, and Thailand. Similar to the African region, this region's primary focus is on educating and accrediting both HCPs and FPs, with alternating training courses being held for one or the other constituency every month. 


\section{Acknowledgments}

We would like to acknowledge the scientific and programmatic contributions provided by the global EIM network, including EIM's staff and Advisory Board, the EIM Regional Centers and National Task Forces and EIM's global partners: The Coca Cola Company, Technogym, Anytime Fitness, and DUNK. In particular we would like to acknowledge the following representatives of the global EIM network: Dr. Robert E. Sallis - Chair, EIM Advisory Board; Dr. Louis J. Holtzhausen - Director, African EIM Regional Center; Dr. Wenhua Zhao - Director, Chinese EIM Regional Center; Dr. Ben Tan - Director, Southeast Asian EIM Regional Center; Mr. Chris Tzarimas - Director, Australasian EIM Regional Center.

\section{Corresponding author:}

Adrian Hutber, Exercise is Medicine Vice-President, American College of Sports Medicine Indianapolis, IN, 46202-3233; USA, E-Mail: ahutber@acsm.org

\section{References}

Coleman K.J., Ngor E., Reynolds K., Quinn V.P., Koebnick C., Young D.R., Sternfeld B., Sallis R.E. (2012): Initial validation of an exercise "vital sign", in electronic medical records. Med Sci Sports Exerc. 44 (11): 2071-6.

Duperly J., Collazos V., Paez C., Donado C., Pratt M., Lobelo F. (2004): Exercise is Medicine in Latin America: training health care professionals in physical activity prescription. Schweiz. Z. Sportmed. Sporttraumatol. 62 (2): 38-41.

GAPA (2010): The Toronto Charter for Physical Activity: A Global Call to Action. Global Advocacy Council for Physical Activity GAPA, International Society for Physical Activity and Health ISPAH (www.globalpa.org.uk). Hallal P.C., Andersen L.B., Bull F.C., Guthold R., Haskell W., Ekelund U. and the Lancet Physical Activity Series Working Group. (2012): Global physical activity levels: surveillance progress, pitfalls, and prospects. Lancet. 380: 247-257.

Heath G.W., Parra D.C., Sarmiento O.L., Andersen L.B., Owen N., Goenka S., Montes F., Brownson R.C. and the Lancet Physical Activity Series Working Group. (2012): Evidence-based intervention in physical activity: lessons from around the world. Lancet. 380 (9838): 272-81.

Lee I.M., Shiroma E.J., Lobelo F., Puska P., Blair S.N., Katzmarzyk P.T. and the Lancet Physical Activity Series Working Group. (2012): Effect of physical inactivity on major non-communicable diseases worldwide: an analysis of burden of disease and life expectancy. Lancet. 380: 219-229. Leijon M.E., Bendtsen P., Nilsen P., Ekberg K., Ståhle A. (2008): Physical activity referrals in Swedish primary health care - prescriber and patient characteristics, reasons for prescriptions, and prescribed activities. BMC Health Serv Res, 8: 201.
Lin JS, O’Connor E, Whitlock EP, Beil T.L., Zuber S.P., Perdue L.A., Plaut D., Lutz K. (2010): Behavioral Counseling to Promote Physical Activity and a Healthful Diet to Prevent Cardiovascular Disease in Adults: Update of the Evidence for the U.S. Preventive Services Task Force. 2010 Evidence Synthesis No. 79. AHRQ Publication No. 11-05149-EF-1. Agency for Healthcare Research and Quality, Rockville.

Malta D.C., Barbosa da Silva J. (2012): Policies to promote physical activity in Brazil. Lancet. 380 (9838): 195-6.

Martin-Diener E., Sonja S., Vuillemin A., van Mechelen W., Vasankari T., Racioppi F., Martin B. (2014): 10 years of HEPA Europe: what made it possible and what is the way into the future? Schweiz. Z. Sportmed. Sporttraumatol. 62 (2): 6-12.

Murphy S.M., Edwards R.T., Williams N., Raisanen L., Moore G., Linck P., Hounsome N., Din N.U., Moore L. (2012): An evaluation of the effectiveness and cost effectiveness of the National Exercise Referral Scheme in Wales, UK: a randomised controlled trial of a public health policy initiative. J Epidemiol Community Health. 66 (8): 745-53.

Orrow G., Kinmonth A.L., Sanderson S., Sutton S. (2012): Effectiveness of physical activity promotion based in primary care: systematic review and meta-analysis of randomised controlled trials. BMJ. 344: e1389.

Patrick K., Pratt M., Sallis R.E. (2009): The healthcare sector >s role in the U.S. national physical activity plan. J Phys Act Health. 6 Suppl 2: S 211-9. Pavey T.G., Taylor A.H., Fox K.R., Hillsdon M., Anokye N., Campbell J.L., Foster C., Green C, Moxham T, Mutrie N, Searle J, Trueman P, Taylor RS. (2011): Effect of exercise referral schemes in primary care on physical activity and improving health outcomes: systematic review and meta-analysis. BMJ 343:d6462.

Pratt M., Norris J., Lobelo F. (2012): The cost of physical inactivity: moving into the 21st century. Br J Sports Med doi: 10.1136/bjsports-2012-091810 Sallis R. (2011): Developing healthcare systems to support exercise: exercise as the fifth vital sign. Br J Sports Med. 45 (6): 473-4.

Sallis R.E. (2009): Exercise is medicine and physicians need to prescribe it! Br J Sports Med. 43 (1): 3-4.

Simons-Morton D. and the Writing Group for the Activity Counseling Trial Research Group. (2001): Effects of physical activity counseling in primary care: the Activity Counseling Trial: a randomized controlled trial. JAMA; 286 (6): 677-87.

Swinburn B.A., Walter L.G., Arroll B., Tilyard M.W., Russell D.G. (1998) The green prescription study: a randomized controlled trial of written exercise advice provided by general practitioners. Am J Pub Health; 88 (2): 288-91.

WHO (2004). Global Strategy on Diet, Physical Activity and Health. World Health Organization, Geneva.

WHO (2013a): Draft comprehensive global monitoring framework and targets for the prevention and control of noncommunicable diseases. World Health Organization, Sixty-six World Health Assembly.

WHO 2013b): Global Action plan for the prevention and control of Noncommunicable diseases 2013-2020. World Health Organization, Geneva. WHO Global Health Risks (2009): Mortality and burden of disease attributable to selected major risks. World Healh Organization, Geneva.

Williams N.H., Hendry M., France B., Lewis R., Wilkinson C. (2007): Effectiveness of exercise-referral schemes to promote physical activity in adults: systematic review. Br J Gen Prac. 57 (545): 979-86. 


\section{Kurse - Zertifikationskurs - Examen - Sportmed Tag - Kongress}

\section{Cours - Cours de certification - Examen- Journée Sportmed - Congrès}

\begin{tabular}{llll}
\hline Art/Genre & Ort/Lieu & Datum/Date & Bemerkungen/Commentaires \\
\hline Kurs/Cours & Magglingen & $24 . / 25.01 .2014$ & ausgebucht/complet \\
Kurs/Cours & Tenero & $10 .-12.04 .2014$ & ausgebucht/complet \\
Kurs/Cours & Nottwil & $16 . / 17.05 .2014$ & ausgebucht/complet \\
Kurs/Cours & Zürich & $25 .-27.06 .2014$ & ausgebucht//complet \\
Kurs/Cours & Sion & $28 .-30.08 .2014$ & ausgebucht//omplet \\
Kurs/Cours & Lausanne & $19 . / 20.09 .2014$ & ausgebucht//omplet \\
Kurs/Cours & Genève & $30.10 .-01.11 .2014$ & ausgebucht/complet \\
\hline Zertifikationskurs & Basel & $28 . / 29.11 .2014$ & \\
Cours de certification & Bâle & $28 . / 29.11 .2014$ & \\
\hline Examen 2015 & Ittigen/Bern & Datum folgt & Anmeldeschluss 15.11.2014 \\
Examen 2015 & Ittigen/Berne & Date suit & Délai d'inscription 15.11.2014 \\
\hline Sportmed Tag 2014 & Ittigen/Bern & 22.05 .2014 & \\
Journée Sportmed 2014 & Ittigen/Berne & 22.05 .2014 & \\
Weiterbildungskurs & Ittigen/Bern & $06 .-10.10 .2014$ & \\
Cours de form. postgrad Testing and Procedures in Sports Medicine & Ittigen/Berne & 06.-10.10.2014 & \\
Fortbildungstag SGSM «SPU» & Nottwil & 13.11 .2014 & \\
Journée de formation continue SSMS «EMS» & Nottwil & 13.11 .2014 & \\
Schweizer Sportmedizin Kongress 2014 & Interlaken & $23 . / 24.10 .2014$ & \\
Congrès Suisse de Médecine du Sport 2014 & Interlaken & $23 . / 24.10 .2014$ & \\
\hline Für weitere Fortbildungsveranstaltungen mit SGSM Credits: & www.sgsm.ch & \\
Pour d'autres journées de formation continue avec crédits SSMS: & www.ssms.ch & \\
\hline
\end{tabular}




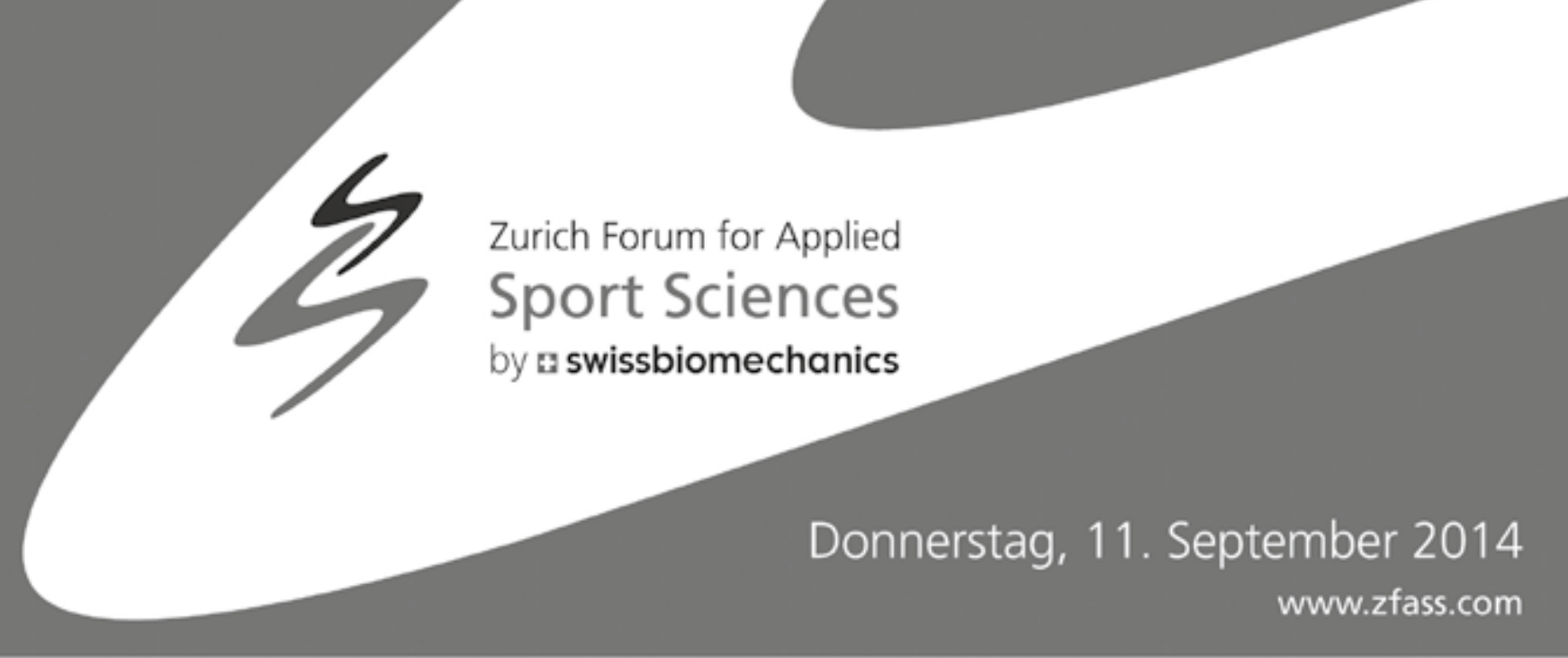

Auch dieses Jahr richtet sich das Forum in erster Linie an alle Ärzte, Therapeuten und Trainer, die ihre Athleten gemäss den neuesten Erkenntnissen aus Sportbiomechanik, Sportphysiologie und Trainingslehre betreuen und so neue Massstäbe setzen wollen (Mediziner, Physiotherapeuten, Chiropraktoren, Trainer und auch Athleten).

Referenten

\section{PD Dr. Lukas Zahner}

Departement fur Sport, Bewegung unid Gesunchelt Basel, CH

Integrative Bewegungsförderung am Beispiel der Sturzprävention

\section{Prof. Dr, med. Heinz Lohrer}

Sportmedizinisches Institut Frankfurt am Main, DE

Achillessehnenruptur im Turnsport und wie sich ein Comeback gestalten lässt

\section{Prof. Dr. rer. Nat. Lutz Jäncke}

Psychologisches institut Universitat Zurich, $\mathrm{CH}$

Credit Sulsse Award for Best Teaching

Bewegungslernen im Sport und dessen Auswirkungen auf unser Gehim

\section{Dr. Michael Vogt}

Sportwissenschafter und Leiter Fachgruppe Ausdauer von Swiss Olympic. Leiter Forschung bei Swiss-Ski

Exzentrisches Training - Belastungsmonitoring

\section{Dr. Hanspeter Gubelmann}

ETH:Zurich Institut für Werhaltenswissenschaften

Sportpsychologie im Spitzensport

* Fragen können vorab bei der Anmeldung via Internet gestelit werden.

\section{Ort}

ETH Zürich, Hönggerberg

Campus Science City

Gebaude $\mathrm{HCl}_{\text {, Raum } \mathrm{G} 3}$

\section{Datum}

11. September 2014

Zeit

$08.00-17.00$ Uhr

Vortragssprache

Deutsch

Aufbau der Referate

25 Minuten Präsentation/wissenschaftlicher Vortrag

05 Minuten Reflektion

30 Minuten Praxisanleitung

30 Minuten moderierte Diskussion / Fragen*

Kosten

CHF 280.00

Anerkannte Weiterbildung SGSM, Chirosuisse, SVDE, phisioswiss, reha-schweiz, Svomp, QualiCert

Anmeldung/Infos/Programm unw.zfass.com

\section{medbaSE}

sports medical center zurich
핀.1

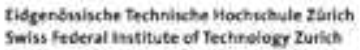




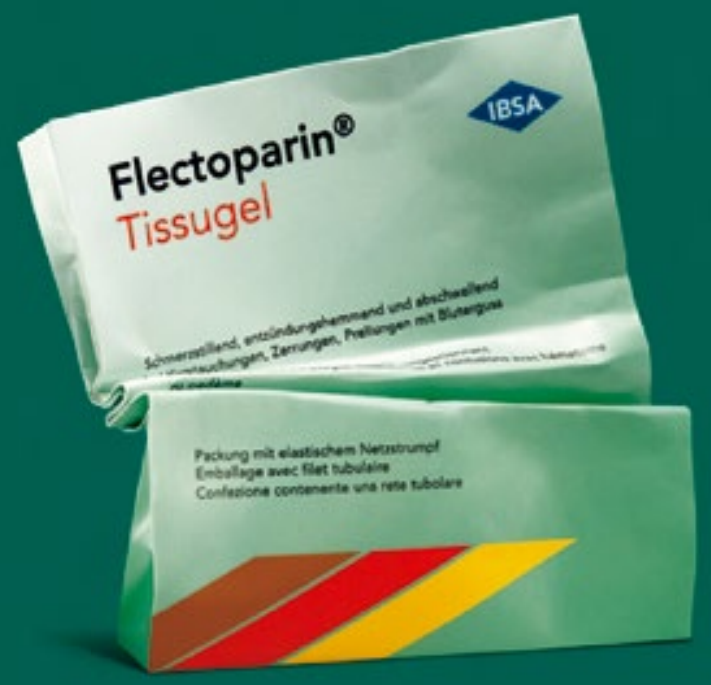

\section{Bei Verstauchungen}
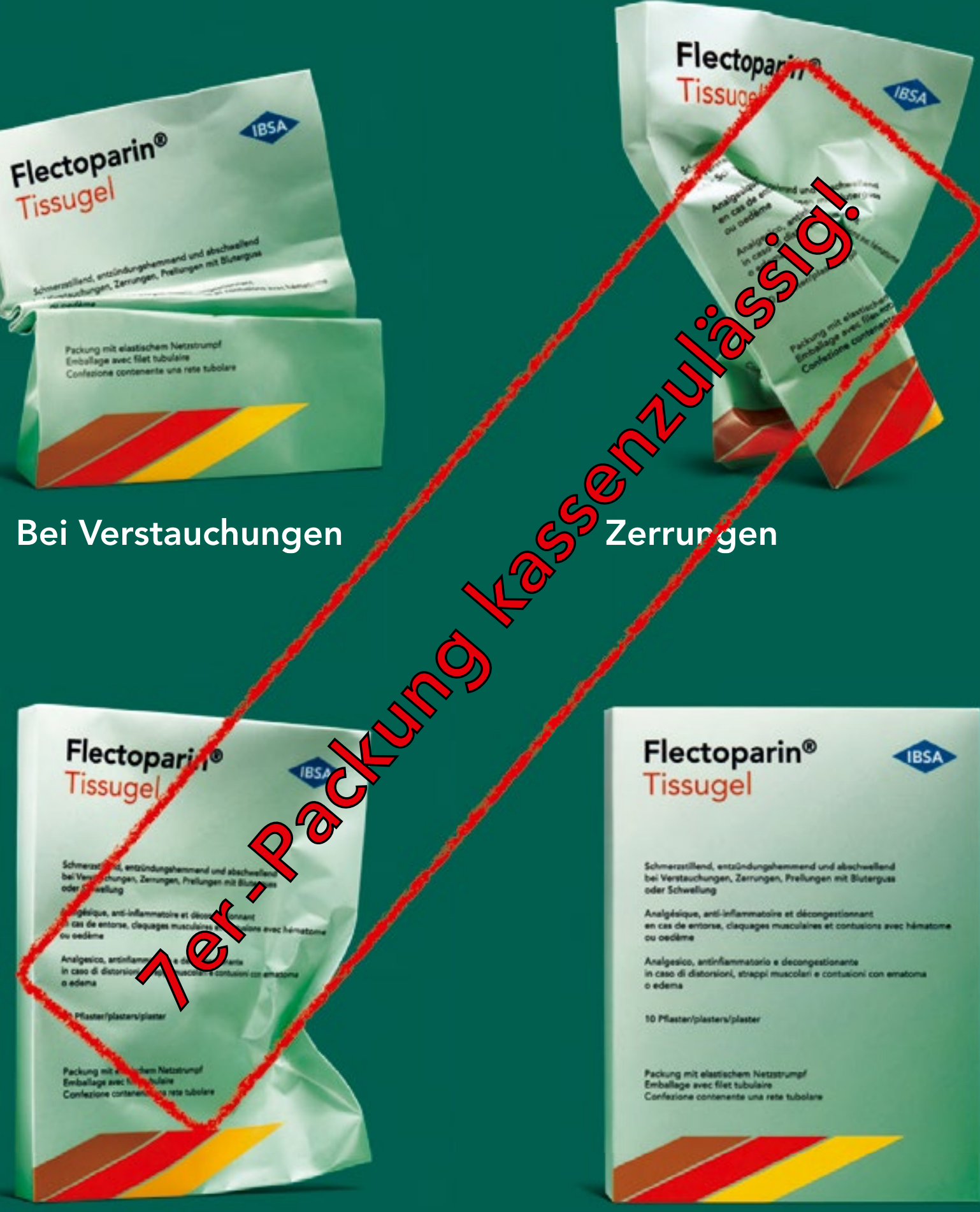

\section{und Prellungen}

\section{mit Bluterguss oder Schwellung}

Für eine schnellere Rückbildung von Bluterguss oder Schwellung. Lindert den Schmerz und hemmt die Entzündung. Einfach in der Anwendung für eine bessere Compliance. Auch nachts wirksam. 